\title{
FEASIBILITY AND RISK STUDY OF A GEOTHERMAL POWER PLANT AT THE SALTON SEA KGRA
}

Phase I Interim Report

\author{
Prepared for \\ San Diego Gas and Electric Company
}

Prepared by

Bechtel National, Inc. The Ben Holt Company San Francisco, California and Pasadena, California

Printed Under Contract GTF-00166

May 10,1978 


\section{DISCLAIMER}

This report was prepared as an account of work sponsored by an agency of the United States Government. Neither the United States Government nor any agency Thereof, nor any of their employees, makes any warranty, express or implied, or assumes any legal liability or responsibility for the accuracy, completeness, or usefulness of any information, apparatus, product, or process disclosed, or represents that its use would not infringe privately owned rights. Reference herein to any specific commercial product, process, or service by trade name, trademark, manufacturer, or otherwise does not necessarily constitute or imply its endorsement, recommendation, or favoring by the United States Government or any agency thereof. The views and opinions of authors expressed herein do not necessarily state or reflect those of the United States Government or any agency thereof. 


\section{DISCLAIMER}

Portions of this document may be illegible in electronic image products. Images are produced from the best available original document. 


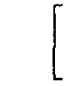

$(2$

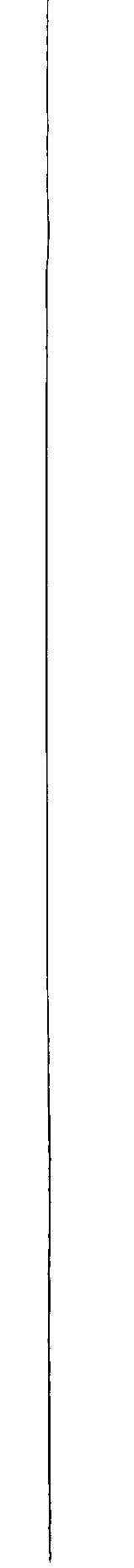


ABSTRACT

This report contains the results of a feasibility and risk study performed by Bechtel National, Inc. and the Ben Holt company under contract to the San Diego Gas and Electric Company (SDGEE) The purpose of the study was to define the most technically feasible and lowest cost near-term energy conversion process for a 50 MWe geothermal power plant at the salton sea known Geothermal Resource Area (KGRA). Using the latest information from the: Geothermal Loop Experimental Facility (GLEF), which is currently in operation at the Salton sea KGRA, conceptual designs, capital cost estimates, and busbar energy production cost estimates were developed for power plants employing several versions of flashed steam and flash binary energy conversion processes. A power plant and well field risk analysis was also performed.

The results show that while the flashed steam plant has the advantage of lower plant capital cost, the brine flow rate required by the binary plant is lower. This results in busbar energy production costs for the two plants that are the same to within the accuracy of the estimates. However, the risk analysis indicates that the technical risks are less for the: flashed steam plant. Therefore, the flashed steam process was selected for further work at the GLEF. The version of the flashed steam process with lowest energy production cost was the dual-flash process with three 50 percent capacit:y trains of flash tanks with unmodified brine Thus, it was determined that GIFF testing in 
the immediate future should be directed primarily toward this process.

A series of GLEF tests and further studies were defined for the purpose of alleviating or minimizing the major risks associated with the flashed steam process. The most important risks were found to be those associated with brine handling. They include producing the brine, carrying it through the plant, and injecting it into the subsurface formation. 
CONTENTS

\begin{tabular}{|c|c|c|c|}
\hline Section & & Page \\
\hline & \multicolumn{2}{|l|}{ ABSTRACT } & iii \\
\hline 1 & \multicolumn{2}{|c|}{ INTRODUCTION } & $1-1$ \\
\hline 2 & \multicolumn{2}{|c|}{ SUMMARY, CONCLUSIONS, AND RECOMMENDATIONS } & $2-1$ \\
\hline 2.1 & \multicolumn{2}{|c|}{ Summary } & $2-1$ \\
\hline 2.2 & \multicolumn{2}{|c|}{ Conclusions } & $2-7$ \\
\hline 2.3 & \multicolumn{2}{|c|}{ Recommendations } & $2-8$ \\
\hline 3 & INTERFACE & AND DESIGN PARAMETERS & $3-1$ \\
\hline \multirow[t]{9}{*}{3.1} & \multicolumn{3}{|c|}{ Interface Parameters } \\
\hline & 3.1 .1 & Brine Supply & $3-1$ \\
\hline & 3.1 .2 & Brine Injection & $3-4$ \\
\hline & 3.1 .3 & Water systems & $3-5$ \\
\hline & 3.1 .4 & Electrical & $3-5$ \\
\hline & 3.1 .5 & Institutional & $3-6$ \\
\hline & 3.1 .6 & Environmental Considerations & $3-6$ \\
\hline & 3.1 .7 & Brine Treatment Prior to Injection & $3-6$ \\
\hline & 3.1 .8 & Scale Cleaning & $3-7$ \\
\hline \multirow[t]{8}{*}{3.2} & \multicolumn{2}{|c|}{ Design Parameters } & $3-7$ \\
\hline & 3.2 .1 & Mechanical & $3-7$ \\
\hline & 3.2 .2 & Auxiliary Systems & $3-8$ \\
\hline & 3.2 .3 & Civil/structural & $3-8$ \\
\hline & 3.2 .4 & Electrical Systems & $3-9$ \\
\hline & 3.2 .5 & Controls and Instrumentation & $3-10$ \\
\hline & 3.2 .6 & Materials & $3-10$ \\
\hline & 3.2 .7 & Scale Buildup & $3-11$ \\
\hline
\end{tabular}


4.1

4.1.1 Tradeoff Analyses

$4-1$

4.1 .2

Cases Studied

$4-4$

4.1.3 Energy Conversion Process

$4-6$

4.1.4 Power Plant Facilities

$4-18$

4.1 .5

Well Field Facilities

$4-38$

4.2 Cost Estimate

$4-39$

4.2.1 Capital cost of Power Plant

$4-41$

4.2.2 Capital Cost of Well Field

$4-41$

4.2 .3

capacity Factors

$4-48$

4.2 .4

Energy Production Costs

$4-50$

5

BINARY PROCESS

$5-1$

5.1

Conceptual Design

$5-1$

5.1 .1

Tradeoff Analyses

$5-2$

5.1.2 Energy Conversion Processes

$5-2$

5.1 .3

Power Plant Facilities

$5-19$

5.1 .4

Well Field Facilities

$5-19$

$5-19$

$5-19$

5.2.1 Capital Cost of Power Plants

$5-28$

5.2.2 Capital Cost of Well Fields

$5-28$

5.2 .3

Capacity Factors

$5-31$

5.2.4 Energy Production Costs

$6-1$

$6-1$

6.1

COMPARISONS

$6-4$

6.2

Technical

$6-5$

6.3

Operation and Maintenance

6-6

6.4

Capital Costs

$7-1$

7

Energy Production Costs

$7-1$ 
7.2

Power Plant

$7-7$

7.3

Reservoir Characteristics - Injection

$7-13$

7.4

Risk Priorities

$7-16$

RESEARCH AND DEVELOPMENT RECOMMENDATIONS

8-1

Recommended Geothermal Loop Experimental

Facility (GLEF) Activities

$8-2$

8.1.1

Test Format

$8-2$

8.1 .2

Test Assumptions

$8-3$

8.1.3

Operational Procedures

$8-5$

8.1.4 Recommended Tests

$8-5$

8.2

other Recommended Activities

8-56

Appendix

A

Cost Estimating Methodology

$A-1$

B

Project Conference Notes

$B-1$ 


\section{ILLUSTRATIONS}

Figure

Page

4-1 Dual Flash Energy Conversion Process Cycle Diagram (No Minimum Injection Temperature Limit) 4-7

4-2 Dual Flash Energy Conversion Process Cycle Diagram (300F Minimum Temperature Limit) 4-8

4-3 Drawing No. M-100-A, Dual Flash Flow Diagram (No Minimum Temperature Limit)

$4-11$

4-4 Drawing No. M-100-B, Dual Flash Flow Diagram (300F Minimum Temperature Limit)

4-5 Drawing No. C-100-Al, Plot Plan, Dual Flash With Unmodified Brine (No Minimum Injection Temperature Limit)

$4-19$

4-6 Drawing No. C-100-A2, Plot Plan, Dual Flash With Acidified Brine (No Minimum Injection Temperature Limit)

$4-21$

4-7 Flash Vessel with Mist Eliminators

$4-25$

5-1 Drawing No. 7748-D-3202, Binary Power Plant, Four-Stage Flash Binary Process

$5-5$

5-2 Temperature Enthalpy Diagram, Four-Stage Flash Binary Process

$5-7$

5-3 Drawing No. 7748-D-3203, Binary Power Plant, Two-Stage Flash Binary, Process

$5-9$

5-4 Temperature Enthalpy Diagram, Two-Stage Flash Binary Process

5-5 Drawing No. 7748-D-3201, Binary Power Plant, Liquid/Liquid Binary Process

5-6 Temperature Enthalpy Diagram, Liquid/Liquid Binary Process

5-7 Drawing No. 7748-D-3204, Binary Power Plant with Flashed Steam/Working Fluid Heat

Exchanger - Plot Plan

Table

$2-1$

Comparison of Flashed Steam and Binary Processes 2-3

$3-1$

Parameter Bases and Sources

$3-2$ 
4-1 Plant Performance Parameters 4-10

4-2 Power Plant Auxiliary Loads 4-16

4-3 Well Schedule 4-17

4-4 Equipment List 4-29

4-5 Capital Cost Estimate Summary 4-40

4-6 Capital Cost Estimate, No Minimum Brine Injection Temperature, Unmodified Brine, Capacity

Factor $85 \%$

4-7 Capital Cost Estimate, No Minimum Brine Injection Temperature, Unmodified Brine, Capacity

Factor $71 \%$

4-8 Capital Cost Estimate, No Minimum Brine Injection Temperature, Acidified Brine, Capacity Factor $85 \%$

4-9 Capital Cost Estimate, No Minimum Brine Injection Temperature, Acidified Brine, Capacity Factor $71 \%$

4-10 Capital Cost Estimate, No Minimum Brine Injection Temperature, Acidified Brine, Capacity

Factor 71 응

4-11 Capital Cost Estimate, Well Field 4-47

4-12 Energy Production Cost Estimates 4-51

5-1 Plant Performance 5-18

5-2 Major Equipment - Four-Stage Flash Binary

$\begin{array}{lr}\text { Process } & 5-20\end{array}$

5-3 Major Equipment - Two-Stage Flash Binary Process 5-23

5-4 Major Equipment - Liquid/Liquid Binary Process 5-24

5-5 Capital Cost Estimate, Power Plant, No Minimum Brine Injection Temperature, Acidified Brine, Capacity Factor 85\%

5-6 Capital Cost Estimate, Power Plant, No Minimum Brine Injection Temperature, Unmodified Brine, Capacity Factor $71 \%$

5-7 Capital Cost Estimate, Power Plant, 300F Brine Injection Temperature, Unmodified Brine, Capacity Factor $71 \%$ 
5-8 Capital Cost Estimate, No Minimum Brine Injection Temperature, Acidified Brine, Capacity Factor $85 \%$

5-9 Capital cost Estimate, Well Field, start of Run

Energy Production Cost Estimates

$5-32$

$6-1$

Plant Performance Comparison

$6-2$

$6-2$

Total Capital Cost

$6-5$

$6-3$

Comparison of Energy Production Costs

$6-7$

$7-1$

Risks

$7-17$

$8-1$

Recommended Tests for the GLEF

$8-7$

$8-2$

Schedule of Recommended 'Tests

$8-8$

$8-3$

Recommended Activities

$8-57$

$A-1$

Capital Costs Estimates, Power Plant

A-3

$A-2$

Power Plant Operation and Maintenance Cost

A -12 
Section 1

INTRODUCTION

The primary objective of the feasibility and risk study is to define the most technically feasible and lowest cost near-term energy conversion process for a comnercial-scale, nominal 50 MWe (net) capacity demonstration power plant at the salton sea known Geothermal Resource Area (KGRA). The purpose of the Geothermal Loop Experimental Facility (GLEF) at the salton sea KGRA is to obtain data for such a power plant. It utilizes the four-stage Elash binary energy conversion process. However, the GLEF design was based on certain conditions and assumptions that have been shown to be no longer valid. Therefore, this study was initiated to determine the most appropriate energy conversion process for the demonstration power plant based on current information and to define future GLEF testing needed to obtain critical design information for the type of plant selected.

The study has been divided into three phases. Phase I, which is reported herein, is a preliminary assessment. Phase II is to. be an updated assessment. It will be performed following a series of GIEF tests that will be based on the results of the phase I study. Phase III is a more detailed study that will follow additional GIEF testing based on the phase II study results.

The Phase I study was jointly performed by Bechtel National. Inc. (Bechtel) and The Ben Holt Company (Holt) for the san Diego Gas and Electric Company (SDGEE). Bechtel and Holt were each 
assigned primary responsibility for different portions of the study, but both were to concur in the other's results. Specific tasks performed by Bechtel include the conceptual designs and cost estimates for the flashed steam energy conversion processes, the interface and design parameters, and the research and development recommendations. Tasks performed by Holt include the conceptual designs and costs estimates for the binary energy conversion processes and the risk analyses.

Both Holt and Bechtel contributed to this report. sections 5, 6, and 7 were prepared by Holt. All other sections were prepared by Bechtel.

Periodic review meetings were conducted by SDGEE throughout the study. In addition to Bechtel and Holt, regular participants in these meetings included the Department of Energy (DOE), Lawrence Berkeley Laboratory (LBL, Lawrence Livermore Laboratory (LLL), and Imperial Magma (Magma). These additional participants supplied information for the study in their particular areas of expertise. 
Section 2

SUMMARY, CONCLUSIONS, AND RECOMMENDATIONS

This section presents a summary of the study and includes conclusions and recommendations.

\subsection{SUMMARY}

In order to ensure that the conceptual designs reflected the latest GIEF data and that the results for the various designs would be comparable, a set of interface and design parameters was developed for use as the power plant and well field design criteria. Additionally, a standard cost estimating methodology was devised to attain compatibility between the various cost estimates.

The most important parameters are as follows:

- Net plant output is 50 MWe.

- The plant is located within the salton Sea KGRA, approximately 2,500 feet west of Gentry Road and 2,000 feet south of sinclair Road.

- Steam condensate is used as cooling tower makeup. and injection flow is decreased by this amount.

- A stretford unit is used for hydrogen sulfide abatement.

- A settling pond is provided for removal of suspended solids from the brine prior to injection.

- Wellbottom temperature is 500F initially and declines linearly to $482 \mathrm{~F}$ in 30 years. The designs are based on $482 \mathrm{~F}$. 
- Total dissolved solids content of the brine is 20 percent, and noncondensible gas content is 0.5 weight-percent of the total brine flow.

- Production flow rate per well is $400,0001 \mathrm{~b} / \mathrm{hr}$. declining linearly to $300,000 \mathrm{lb} / \mathrm{hr}$ in 30 years. Injection flow rate per we 11 is 600,000 lb/hr and remains constant.

- The production wells are slant drilled from an island located adjacent to the power plant. Injection wells are slant drilled from an island approximately 3,000 feet from the production well island.

- Brine sacling rates, scale removal techniques and costs, and material for use in brine service are based on GLEF data.

Conceptual designs, capital cost estimates, and energy production cost estimates were developed for five versions of the dual flashed steam energy conversion process and four versions of the binary process. These processes are listed in Table 2-1, which compares their performance, capital costs, and energy production costs. Capital costs and energy production costs were escalated to the first quarter 1982 .

The plant capital costs for the binary processes are generally higher than the flashed steam processes. However, since the performance is somewhat greater for the binary processes, their brine requirements are lower and their well field capital costs are lower. The result is that busbar energy production costs for comparable versions of the flashed steam and binary processes are the same to within the accuracy of the estimates. 
TABLE 2-1

COMPARISON OF FLASHED STEAM AND BINARY PROCESSES

50 MWe NET DUAL FLASH ENERGY CONVERSION

SALTON SEA KGRA, NILAND, CALIFORNIA

\begin{tabular}{|c|c|c|c|c|}
\hline & Specific & $\begin{array}{r}\text { Capital } \\
10^{6}\end{array}$ & ost $(1)$ & Energy ${ }^{(1)}$ \\
\hline & $\begin{array}{l}\text { Watt } \mathrm{hr} / 1 \mathrm{~b} \\
\text { Br:ine }\end{array}$ & $\begin{array}{l}\text { Well } \\
\text { Field }\end{array}$ & $\begin{array}{l}\text { Power } \\
\text { Plant }\end{array}$ & $\begin{array}{l}\text { Cost } \\
\text { Mi11s/kWh }\end{array}$ \\
\hline Flashed Steam Process & & & & \\
\hline $\begin{array}{l}\text { Unmodified Brine, No Minimum } \\
\text { Injection Temperature, with } \\
\text { Redundant Flash Vessels }\end{array}$ & 8.90 & 9.83 & 38.4 & 37.6 \\
\hline $\begin{array}{l}\text { Unmodified Brine, No Minimum } \\
\text { Injection Temperature }\end{array}$ & 8.90 & 9.83 & 37.2 & 44.1 \\
\hline $\begin{array}{l}\text { Acidified Brine, No Minimum } \\
\text { Injection Temperature }\end{array}$ & 8.90 & 9.83 & 38.2 & 38.5 \\
\hline $\begin{array}{l}\text { Unmodified Brine, 300F Minimum } \\
\text { Injection Temperature }\end{array}$ & 8.21 & 11.00 & 37.0 & 46.6 \\
\hline $\begin{array}{l}\text { Acidified Brine, 300F Minimum } \\
\text { Injection Temperature }\end{array}$ & 8.21 & 11.00 & 39.1 & 49.3 \\
\hline Binary Process & & & & \\
\hline $\begin{array}{l}\text { Acidified Brine, No Minimum } \\
\text { Injection Temperature (four- } \\
\text { stage flash) }\end{array}$ & 9.35 & 9.04 & 40.35 & 38.7 \\
\hline $\begin{array}{l}\text { Unmodified Brine, No Minimum } \\
\text { Injection Temperature (four- } \\
\text { stage flash) }\end{array}$ & 9.35 & 9.04 & 39.54 & 43.7 \\
\hline $\begin{array}{l}\text { Unmodified Brine, } 300 \mathrm{~F} \text { Minimum } \\
\text { Injection Temperature (two-stage } \\
\text { flash) }\end{array}$ & 7.65 & 11.05 & 38.78 & 46.6 \\
\hline $\begin{array}{l}\text { Acidified Brine, No Minimum } \\
\text { Injection Temperature } \\
\text { (liquid/1iquid) }\end{array}$ & 10.54 & 8.22 & 43.70 & 38.7 \\
\hline
\end{tabular}

Notes: (1) Escalated to first quarter 1982.

(2) Cost of wells installed at Year 0. 
The 300F minimum injection temperature processes were: studied as an alternative to using brine settling ponds for solving the brine injection problem. However, the results show that these processes have lower performances and higher energy production costs than a process using no minimum injection temperature and including brine settling ponds.

The most cost effective of the binary processes studied is the four-stage flash process with acidified brine. It has an energy production cost of $38.7 \mathrm{mills} / \mathrm{kWh}$. The energy cost for the comparable flashed steam process with acidified brine, $38.5 \mathrm{mills} / \mathrm{kWh}$, is not considered to be significantly different. An energy production cost of $37.6 \mathrm{mill} / \mathrm{kWh}$, the lowest cost of the processes studied, was estimated for the dual flashed steam process with unmodified brine and three 50 percent capacity flash vessel trains. Since one train is redundant, it can be descaled while the plant is operating at full capacity.

The risk analysis was performed that covers the major concerns at this point in the development of the project. These risks affect the basic go or no-go decisions. The risks were assessed, and priorities were assigned. The results of this analysis show that brine handling is the most important technical risk. Involved in this risk are the problems of scale formation, corrosion, and two-phase flow in production wells, injection wells, and plant equipment and instrumentation. If satisfactory means can be found for producing the brine, carrying it through the power plant, and injecting it into the subsurface formation, the 
project will have a high probability of success. Additional technical risks include noncondensible gases and steam quality, but these problems can be met with known technology.

Environmental risks that were identified include ground subsidence, air pollution by hydrogen sulfide, and disposal of liquid effluents. The long-term availability of water is, possibly, another risk. It becomes a risk only if it is found that the amount of water injected must equal that produced in order to prevent subsidence.

Economic risks involve the need for improved information of capital costs for both the plant and the well field. The existence of an adequate energy source has been reasonably well established. However, the ability to deliver the brine to the plant and to inject the discharged brine into the subsurface formation at acceptable costs have not been demonstrated. Plant availability, or capacity factor, was found to significantly affect the energy production cost. It is extremely important to maintain high availability. The test program must demonstrate that this can be accomplished by the use of either an on-line scale cleaning method, standby equipment, or the prevention of scale formation by brine modification techniques. Considering all of the risks identified, the major technical risks described above are of greatest concern. They should be the first addressed in future GLEF testing. 
The results of this study indicate that the most appropriate energy conversion process for the 50 MWe (net) demonstration power plant is the two-stage flashed steam process using unmodified brine and three 50 percent trains of flash equipment. since existing geothermal flashed steam power plants have demonstrated that low cost electrical power can be produced commercially, investor confidence is much higher for this process than for the commercially untried flashed binary process. Therefore, it is recommended that the GLEF be modified to simulate this process and that future testing be directed primarily toward aleviating, the risks associated with it. However, the option of using modified brine should be kept open. The most cost effective method for accomplishing this would be for the Department of Energy, Industrial Support Program, to operate a small-scale loop for this purpose at their current site next to the GLEF.

Research and development recommendations were defined that will minimize the major identified risks. These recommendations include a series of GLEF tests as well as other activities, such as theoretical studies that do not require the GLEF. The tests assume that the GIEF will be modified to simulate the two-stage flashed steam power plant defined by the conceptual design developed in this study. Both the GLEF tests and the related studies have been ranked in order of their potential to minimize the risks. 
The most appropriate energy conversion process for the $50 \mathrm{MWe}$ demonstration power plant is the twostage flashed steam process using unmodified brine and three 50 percent capacity trains of flash vessels. This is based on an analysis that incorporates the latest GLEF information.

- The capital cost for the two-stage flashed steam plant using unmodified brine and standby flash equipment was estimated to be $\$ 31.6$ million. The capital cost for the corresponding wellfield was $\$ 9.83$ million. The busbar energy production cost was $37.6 \mathrm{mills} / \mathrm{kWh}$. These costs include escalation to first quarter 1982 prices.

- The option of using modified brine with the flashed steam plant should be kept open.

- Plant capital costs are lower for plants incorporating the flashed steam process than for those incorporating the binary process. However, brine requirements and, therefore, well field capital costs are lower for binary plants. The result is that the energy production costs for the flashed steam and binary plants studied are the same to within the accuracy of the estimates.

- The lowest energy production cost of those studied, for the binary process was $38.7 \mathrm{mills} / \mathrm{kWh}$. Plants utilizing the four-stage flash binary process with acidified brine and the liquid/liquid binary process with acidified brine had this same energy production cost.

- No insurmountable risks were identified. The most important risks are those associated with brine handling. If satisfactory means can be found for producing the brine, carrying it through the power plant, and injecting it into the subsurface formation, the project will. have a high probability of success.

- The technical, economic, and risk analyses conducted during this study indicate that the project should be carried forward.

The GLEF should be modified to simulate the twostage flashed steam process. The test program described in this report should be supported by related studies that are also described herein. 
- The $50 \mathrm{MWe}$ (net) demonstration power plant at the Salton sea KGRA should be based on the two-stage flashed steam energy conversion process using unmodifed brine and redundant flash equipment.

- The overall feasibility study should go forward, at least through Phase II, to improve performance and cost data for the power plant and the well field and to find means for overcoming the important risks.

- The GLEF should be modified to simulate a plant using the two-stage flashed steam process with unmodified brine.

- The GLEF test program and supporting studies that are described in this report should be carried out. The test effort should concentrate on the brine handling risks that are considered to be the most critical.

- The option to use modified brine should be kept open. A small-scale loop, simulating the two-stage flashed steam process with modified brine, should be constructed and operated under the Department of Energy, Industrial support Program, at the small test facility currently located next to the GLFF 
Section 3

INTERFACE AND DES IGN PARAMETERS

This section defines the interface and design parameters on which the feasibility study is based. The parameters were established to insure that the plant conceptual designs were done in a realistic, consistent manner. They are based on available data and the engineering judgment of the study participants.

The source of each interface or design parameter is identified where possible. The letters and numbers given in parentheses after each parameter are keyed to Table 3-1 to indicate the basis of the corresponding parameter and the study participant who provided the basis.

3. 1

INTERFACE PARAMETERS

3. 1. 1

Brine Supply

- The site is located in the quadrant defined by U.S. Geological survey Range $13 \mathrm{E}$ and Township 11S. The location of the power plant is approximately 2,500 ft west of Gentry Road and 2,000 ft south of sinclair Road. Brine supply will be from a production well island, which will be located adjacent to the west boundary of the power plant $(1,6, b)$.

- The well island will have two rows of wells, $150 \mathrm{ft}$ apart. Adjacent wells in each row will be spaced at $50 \mathrm{ft}(1,6, \mathrm{~b})$.

Production wells will have 9-5/8 in. casings and will be slant drilled from the island with 600 to $700 \mathrm{ft}$ bottomhole spacing $(2,6, b)$. 
Table 3-1

PARAMETER BASES AND SOURCES

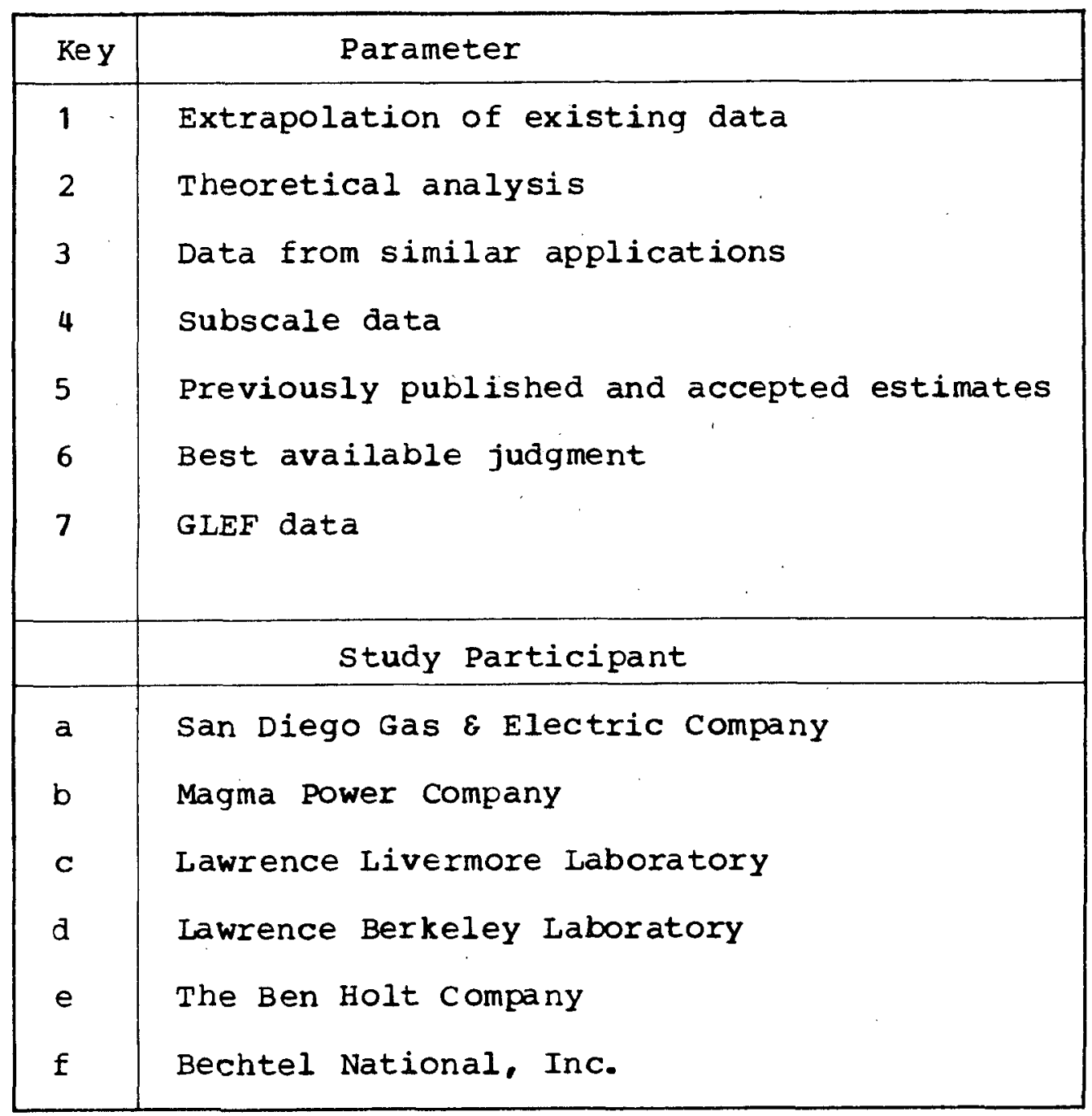


The number of production wells to be used will be selected according to individual plant requirements $(6, b)$.

- The production well system will include the production wells, well head equipment and valves, insulated brine and steam supply lines and headers to the power plant boundary, and flash equipment if necessary. The brine and steam supply lines will be above ground (3, 6, a, b) .

Production wells will be naturally flowing $(2,3, b$, c. d).

Nominal individual production well flow will be $400.0001 \mathrm{~b} / \mathrm{hr}$ declining linearly to $300,0001 \mathrm{~b} / \mathrm{hr}$ at year 30 (2, 3, b, c, d).

spare production wells having $20 \%$ of the plant flow capacity will be provided $(2,3, \mathrm{~b})$.

Brine saturated liquid thermodynamic properties will be based on Lawrence Livermore Laboratory's computer program BPROP2. Brine saturated vapor properties will be obtained by using the brine saturation pressure coefficient given in the computer output table and the ASME Steam Tables $(3, c)$.

- Production wellbottom temperature will be $500 \mathrm{~F}$ declining linearly by $18 \mathrm{~F}$ in 30 years. Plant design will be based on $482 \mathrm{~F}(2,3, \mathrm{C}, \mathrm{d})$.

Total dissolved solids concentration of the brine at the wellbottom will be $20 \%$ and will remain constant over the plant lifetime $(2,3, b, c, d)$.

Enthalpy of the saturated liquid brine will be $389.4 \mathrm{Btw} / \mathrm{b}$ at a temperature of $482 \mathrm{~F}$ and $20 \%$ solids concentration $(2$, d) .

- Wellhead pressure will be 150 psig, remaining constant over a 30-year life (2, 3, b, c, d).

- Noncondensible gas content will be 0.5 weight-percent of the total brine flow (2, 3, 7, b, c, d). 
- Noncondensible gas composition will be as follows (2, $3, b, c, d):$

\section{Percent by volume}

Carbon dioxide
Methane
Nitrogen
Hydrogen
Hydrogen sulfide

$$
\begin{array}{r}
98.47 \\
0.81 \\
0.09 \\
0.62 \\
820 \mathrm{ppm}
\end{array}
$$

- Production well cost will be $\$ 300,000$ each for $4000 \mathrm{ft}$ wells including drilling costs $(3, \mathrm{~b})$.

- It is assumed that the brine will be either acidified for scale control at entry to the power plant and neutralized as it leaves the plant site or unmodified and the plant periodically shut down for scale removal and cleaning $(6, a)$.

Open storage tanks, having a total storage capacity of approximately 60,000 gallons, will be provided at the site for well startup and emergency discharge. They will have drain pumps for emptying to the injection line $(3, b)$.

\section{Brine Injection}

Two injection temperature cases will be studied. They are no minimum temperature limit and minimum temperature of $300 \mathrm{~F}(1,3, a, b)$.

- Pressure required at design flow rate will be 400 psig corresponding to the no minimum injection temperature case and 465 psig corresponding to the $300 \mathrm{~F}$ minimum injection temperature case $(2,7, a, b)$.

For both cases, the design flow rate for each injection well will be $600,0001 \mathrm{~b} / \mathrm{hr}$ and will remain constant over a 30-year life $(2,3, b)$.

- Acidified brine will be neutralized prior to injection, and brine from the no minimum injection temperature cases will have a diked solids settlement pond $(2,3, a, b, c)$.

The injection well system will include the injection wells, insulated brine headers from the power plant boundary, and wellhead equipment including controls (3. 6, a, b). 
- Injection lines from the power plant boundary to the injection wells will be above ground and will be suitably insulated and protected $(3,6, a, b)$.

- Brine injection will be from an injection well island, which will be located near Gentry Road approximately $2,500 \mathrm{ft}$ east of the power plant $(1,6, \mathrm{~b})$.

- Spare injection wells having $20 \%$ of the plant flow capacity will be provided $(2,3, \mathrm{~b})$.

The number of injection wells to be used will be selected according to individual plant requirements (6, b) .

Injection well cost will be $\$ 200,000$ each for 1500 to $1800 \mathrm{ft}$, including drilling costs $(3, \mathrm{~b})$.

\section{1. 3 Water Systems}

- Plant design will be based on a wet bulb temperature of $79 \mathrm{~F}(1, a)$.

- Steam condensate will be used as the main source of cooling tower makeup $(1$, a) .

- Additional makeup will be assumed to be fresh water. which will be available at the industrial rate of $\$ 3.50$ per acre-ft $(1, a)$.

Cooling water blowdown will be discharged to the Salton sea $(3, a)$. (Blowdown piping will be shown and its cost estimated only to the power plant boundary.)

- The blowdown effluent pressure at the power plant site boundary will be 65 psia $(3, \mathrm{f})$.

Since condensate is used as cooling tower makeup, only a minimum amount of blowdown will result. Thus, no treatment of the blowdown is assumed $(3, a)$.

3. 1.4 Electrical

The power plant electrical system will provide power to the local utility company's existing $92 \mathrm{kV}$ network under base load conditions $(6, a)$. 
- Electrical transmission lines outside the power plant site boundary will not be included in the studies 16 . a).

3.1.5 Institutional

- Equipment will be fabricated and installed in accordance with applicable codes and standards that are accepted in the power plant industry $(6, a)$.

- Standard power plant design practice will be followed in the selection and arrangement of power plant equipment $(6, a)$.

- Safety aspects will be considered so that equipment can be operated safely when normal industrial precautions are enforced $(6, a)$.

- Heat emission by evaporation from a cooling tower into the atmosphere will be acceptable (1, 3, e, f).

- In order to meet the air quality standard for hydrogen sulfide emission. noncondensible gases will be treated by the stretford process $(3, e, f)$.

- The hydrogen sulfide ambient air quality 30 perandard of boundary $(7, a)$.

standard of

- Hydrogen sulfide emissions from the cooling tower will be acceptable $(7, a)$.

- Possible induced seismicity will not be considered in this study $(6, a)$.

\section{Brine Treatment Prior to Injection}

Brine flow into the settling pond will have $140 \mathrm{ppm}$ of suspended solids, and brine from the pond will have 40 ppm of suspended solids $(7, b, c)$.

- Sludge at the bott om of the pond will be dewatered in a centrifuge at the rate of 500 lb of solids per million lb of brine $(7, c)$. 
- Cost of hauling the sludge will be $\$ 10 /$ ton $(1$, a) .

- Feed to the centrifuge will have $16 \%$ by weight of solids, and cake discharge from the centrifuge will have 50\% by weight of solids for hauling $(7, \mathrm{c})$.

- Brine sludge from the settling pond and waste discharge from the stretford process will be hauled to a locally acceptable disposal site.

\subsubsection{Scale cleaning}

Plant operation time between cleaning. will be 1000 hours $(7, a)$.

- Total downtime required for cleaning the plant will be two weeks $(7, a)$.

- Fixed costs for scale cleaning, which include the subcontract labor cost for cleaning, will be $\$ 7,500$ for the two-week period $(7, a)$.

- Variable costs for scale cleaning, which include the cost of chemicals during each cleaning period at GLEF, will be $\$ 7,500(7, a)$.

For the conceptual power plants, the variable costs required for cleaning will be prorated from the GLEF variable cost based on the area exposed to brine 17 . a).

3. 2

DESIGN PARAMETERS

3.2.1 Mechanical

Power plants will be designed for a 30-year life $(3, a)$.

- Plants will be designed for base load operation with a constant power output of 50 MWe (net) $(3, a)$.

- Basic plant capacity factor will be 85 percent. Time required for scale cleaning, beyond that allowed for other maintenance, will reduce the plant capacity factor below 85 percent (3, e, f).

- Cooling tower outlet water temperature will be $87 \mathrm{~F}$ (3. f) - 
- Cooling towers will be mechanically induced draft evaporative type (3, e, f) .

- Redundancy will be provided for the injection pumps by using two pumps at $100 \%$ capacity $(7$, a)

Piping insulation will be calcium silicate with canvas jacketing for indoor piping (3. e. f).

\subsubsection{Auxiliary Systems}

The following systems will be included in all studies. The level of design detail will be limited to that necessary to support the overall conceptual design and cost estimating work $(6, a)$ :

- Brine acidification system (acidification cases only)

- Effluent treatment system (no minimum

injection temperature cases only)

- Firefighting systems

- Heating and ventilation system

- Instrument and service air supply system

- Turbine building crane

- cooling water treatment system

\subsubsection{Civil/structural}

Accepted power plant engineering practices and design standards will be followed to establish a technically sound civil/structural design.

- The site is presently used for agricultural purposes, therefore only minimal clearing will be required (6, a).

- Soil suitable for any fill requirements will be available on site $(6, a)$.

- with flat topography, only minimal general excavation and grading will be necessary $(6, a)$.

water table will be $2 \mathrm{ft}$ below grade $(6, \mathrm{~b})$. 
- Allowable soil-bearing pressure will be 1500 psf (7. a)

- All foundations will be of the spread footing type without piling $(7, e, f)$.

- Existing roads adjacent to the site will be capable of supporting transportation of heavy equipment $(6, a)$.

- Turbine building will be rectangular and constructed of structural steel with metal siding and roof. Floor slab at grade will be provided. The turbine generator will be supported by reinforced concrete pedestal with elevated access $\operatorname{deck}(6, f)$.

- Control room will be suitably constructed to conform to safety requirements $(6, \mathrm{f})$.

- Cooling tower will consist of a reinforced concrete basin and wooden structure with fill $(6, f)$.

- Onsite access road from existing road to power plant site will be provided $(6, a)$.

- Additional facilities such as sewage system and security will be provided $(3$, a).

\subsubsection{Electrical systems}

The power plant electrical systems will provide power to the local utility company's existing $92 \mathrm{kV}$ network and the plant a uxiliary loads during normal operation. Power for startup will be supplied from the $92 \mathrm{kV}$ network. The electrical system will consist of at least the following:

- Main Generation System. This will include the main $13.8 \mathrm{kV}$ generator unit, generator breaker, and the main transformer which steps up to the $92 \mathrm{kv}$ system $(1, e, f)$.

Generator will be sized to supply the net electric power plus auxiliary electric power requirements. The generator will be hydrogen cooled $(3, e, f)$.

- Auxiliary Electric systems. This will include the auxiliary transformer and its supply breaker, the 
4. $16 \mathrm{kV}$ and 480 volt subsystems, a standby diesel generator (for emergency power only), batteries and dc systems, a lighting system, and a communication system (3. e. f).

Efficiency of electric motors will be $92 \%(3, e, f)$.

Plant-Utility Interface system. This will include the switchyard and supports for the transmission lines to the plant site boundary (3,e, f).

3.2.5 Controls and Instrumentation

Control and instrumentation systems will be defined only to the extent necessary to support the cost estimates. The control and instrumentation requirements will include the following:

- Provide efficient, reliable operation from a central control room to minimize operator requirements and to allow remote routine startup and shutdown of the plant (3, e, f).

- Use independent trip systems and redundant protection systems for personnel and equipment safety $(3, e, f)$.

- Include a minicomputer for data logging and sequence of events recording $(3, e, f)$.

- Use an annunciator system for alarm monitoring 13 , e, f).

- Provide no extra instrumentation for experimental testing of processes $(6, e, f)$.

3. 2.6 Materials

The material selections and corrosion allowances listed are based on the best available GLEF data. which contain considerable uncertainty and gaps. Nevertheless, the information provides a 
common basis for the preliminary evaluation of the conceptual designs.

The following materials will be used for piping and equipment in contact with acidified brine $(\mathrm{pH}<5)$. For temperature greater than $150 \mathrm{C}(302 \mathrm{~F})$. Hastelloy C-276 liners or $1 \mathrm{Cr} 1 / 2$ Mo alloy steel (or equivalent) with a corrosion allowance of $1 / 2$ in. will be used. For temperature less than $150 \mathrm{C}$ (302F), $1 \mathrm{Cr} 1 / 2$ Mo alloy steel (or equivalent) with corrosion allowance of $1 / 2$ in. will be used $(7, \mathrm{c})$.

- The acidification mixing section in the brine supply line will be 10 times the pipe diameter in length and will be made of carbon steel with a tantalum or zirconium lining. The lining will have a minimum thickness of 0.060 in. $(7, c)$.

- The following materials will be used for piping and equipment in contact with unmodified brine $(\mathrm{pH}>5)$. From production wells to first flash vessel (or separator). carbon steel with $1 / 4$ in. corrosion allowance will be used. From first flash vessel (or separator) to injection wells, carbon steel with $5 / 8$ in. corrosion allowance will be used $(7, c, e$, f).

3.2.7 Scale Buildup

The scale buildup rates listed here are based on the best available GLEF data, which contain considerable uncertainty. Nevertheless, the following information provides a common basis for the preliminary evaluation of the conceptual design. Scale is assumed to build up and then to be removed by cleaning. The scale buildup rates associated with acidified brine in the power plant is assumed to be negligible.

- For production lines, which always carry unmodified brine, a scale buildup rate of $70 \mathrm{mils} /$ year is assumed (7. c). 
- For power plant lines. 1 mil/hour scale buildup rate with unmodified brine in the power plant is assumed. With acidified brine in the power plant, the scale buildup will be negligible $(7, \mathrm{c}$.

- For injection lines, $100 \mathrm{mils} /$ year scale buildup for no minimum injection temperature cases is assumed. For $300 \mathrm{~F}$ injection temperature cases, 1 mil/hour for first 150 meters $(500 \mathrm{ft})$ from the power plant is assumed, then a linear decline is assumed to $0.1 \mathrm{mil} / \mathrm{hour}$ at the injection wells 1750 meters ( $2500 \mathrm{ft})$ from the power plant) $(7, \mathrm{c})$. These rates are applicable with both unmodifed and acidified brine cases, since it is assumed that the injection line always carries neutralized brine. 


\section{section 4}

FLASHED STEAM PROCESS

4. 1 CONCEPTUAL DESIGN

This section describes the conceptual design of a 50 MWe (net) flashed steam power plant based on the interface and design parameters defined in section 3. Five design cases are considered. This conceptual design description is then followed by capital and energy production cost estimates for the five cases.

\section{1. 1 Tradeoff Analyses}

The following tradeoff studies were conducted to aid in formulating the conceptual design.

Number of Flash Stages. Calculations were performed to establish the number of flash stages that can be economically utilized to produce steam for the turbine. These calculations indicated that the specific net output as a function of number of flash stages is as follows:

Number of Flash Stages

1

2

3
Specific Net output (Wh/ Ib brinel (Normalized)

6.61

1.00

8. 30

1. 26

9.08

1. 37 
The turbine-generator and its associated control valves for a two-stage flash plant represent a significant portion percent) of the plant capital cost. With the three-stage flash steam process, the cost of the turbine will increase significantly due to additional steam control valves and increased size of casing to accommodate the third flashed steam admission. In addition, the cost of piping and vessels associated with the third flash will also be significant. It was judged that the performance improvement of 9 percent for the three-stage flash process over the two-stage flash process would not justify the added capital cost. Hence, a two-stage flash plant was selected for the study.

Steam Cleaning Method. Two alternative steam cleaning methods were considered for this application:

- Mist eliminator-type scrubbers

- Hutchinson scrubbers that are being used in the GLEF

Both scrubbers produce dry saturated steam. The flash vessel with mist eliminator-type scrubbers, which is compact and marginally less expensive than the Hutchinson scrubber, has been selected for this study. However, since performance parameters have not yet been established conclusively for the Hutchinson scrubbers being used in the GLEF, final selection of the scrubber should be made after the relative performance of these scrubbers has been established. Furthermore, the overall cost and performance of the power plant will not be significantly 
different using either the Hutchinson or mist eliminator-type scrubber.

Type of condenser. Both surface and direct contact condensers were considered for this application. In a surface condenser. the quantity of noncondensible gases dissolved in the condensate will be nearly zero, since the condensate is at its boiling point. In a direct contact condenser, the condensate is at a temperature less than the boiling point, and the total quantity of water in contact with the gases is about 30 times the quantity of condensate in the surface condenser. Hence, a significant amount of gases could be carried out of the condenser into the cooling towers. Therefore, a surface type condenser has been selected for this study.

Hydrogen sulfide Abatement system. Noncondensible gases consist primarily of carbon dioxide with 820 ppm by volume of hydrogen sulfide. Two possible ways of handling the noncondensible gases have been studied:

- Using the stretford process to recover the sulfur and discharging the tail gas without any appreciable amount of hydrogen sulfide

- Compressing the noncondensible gases and injecting them with the brine back into the ground

The stretford process has been selected because, although both approaches meet the emission and ambient requirements for hydrogen sulfide, the stretford process results in about 6 percent lower overall plant energy cost compared to gas 
compression for injection. The levelized capital and operating cost for the stretford process is approximately $1.35 \mathrm{mills} / \mathrm{kWh}$. This is approximately 3.0 percent of the plant total energy cost. However, a compressor required for compressing the noncondensible gases would consume approximately $3.400 \mathrm{~kW}$ of power and contribute 7 percent of the plant capital cost. Based on this, the energy cost would increase by about 9 percent compared to 3 percent for the stretford process. Hence, the stretford process has been selected for hydrogen sulfide abatement.

4.1.2 Cases Studied

Five conceptual design cases were considered in this study:

- Unmodified brine, no minimum injection temperature. with redundant flash vessels

- Unmodified brine, no minimum injection temperature

- Acidified brine, no minimum injection temperature

- Unmodified brine, 300F minimum injection temperature

- Acidified brine, 300F minimum injection temperature

No Minimum Injection Temperature Cases. Energy available in the geothermal brine for power generation is proportional to the difference in temperature between downhole brine and injection brine. In this case, the injection temperature of the brine has been decreased as low as practicable to obtain the most efficient energy use from the brine. 
A settling pond for a two-hour retention time has been incorporated to minimize the scaling of the injection system. The scaling in the power plant due to brine can be reduced significantly by lowering the brine $\mathrm{pH}$ to below 4.3. This is accomplished by injecting hydrochloric acid into the brine. Both unmodified and acidified brine cases with no minimum limit on the injection temperature have been studied. A second unmodified brine case with redundant flash vessels to allow cleaning of scale without plant shutdown was also considered. When acidification is used, the brine is neutralized by treating it with caustic in the drain line between the second-stage flash vessels and the settling pond.

300F Minimum Injection Temperature Cases. scaling of the injection system is minimized if the injected brine temperature is $300 \mathrm{~F}$ or more. Hence, a minimum brine injection temperature of $300 \mathrm{~F}$ was set. The spent brine is infected without settling in the pond. Acidification of the brine in. the power plant will reduce the scaling of the power plant equipment significantly. Therefore, both unmodified and acidified brine cases with $300 \mathrm{~F}$ minimum injection temperature were studied. When the brine is acidified, it is neutralized by treating it with caustic in the drain line after the second-stage flash vessels. 


\subsubsection{Energy Conversion Processes}

The dual-flash energy conversion processes developed for the no minimum injection temperature and 300F minimum injection temperature cases are illustrated by the cycle diagrams shown in Figures 4-1 and 4-2, respectively. Since brine acidification does not affect the cycle, each diagram represents both the unmodified and acidified brine cases.

The optimum flashed steam temperatures have been found to be at approximately equal intervals between the downhole temperature and the condenser temperature. These temperatures have been used in selecting the flashed steam conditions for these cycles. For the no minimum injection temperature cases, the first-stage flash pressure is set at 130 psia with the brine at 363F, producing dry saturated steam at 347.7F. The second-stage flash pressure is set at 21 psia with brine at $244 \mathrm{~F}$, resulting in dry saturated steam at $230.6 \mathrm{~F}$. Introduction of the wash water for scrubbing the steam results in desuperheating the steam to the dry saturated conditions.

In the $300 \mathrm{~F}$ minimum injection temperature cycle, the first-stage flash pressure is set at 130 psia with brine at 363F, and dry saturated steam at $347.4 \mathrm{~F}$ is produced. The second-stage flash pressure is 53 psia with brine at $300 \mathrm{~F}$, resulting in dry saturated steam at 285F. First-stage conditions for this cycle are the same as for the no minimum injection temperature case, because there is only a 34.7 psi pressure difference between the 


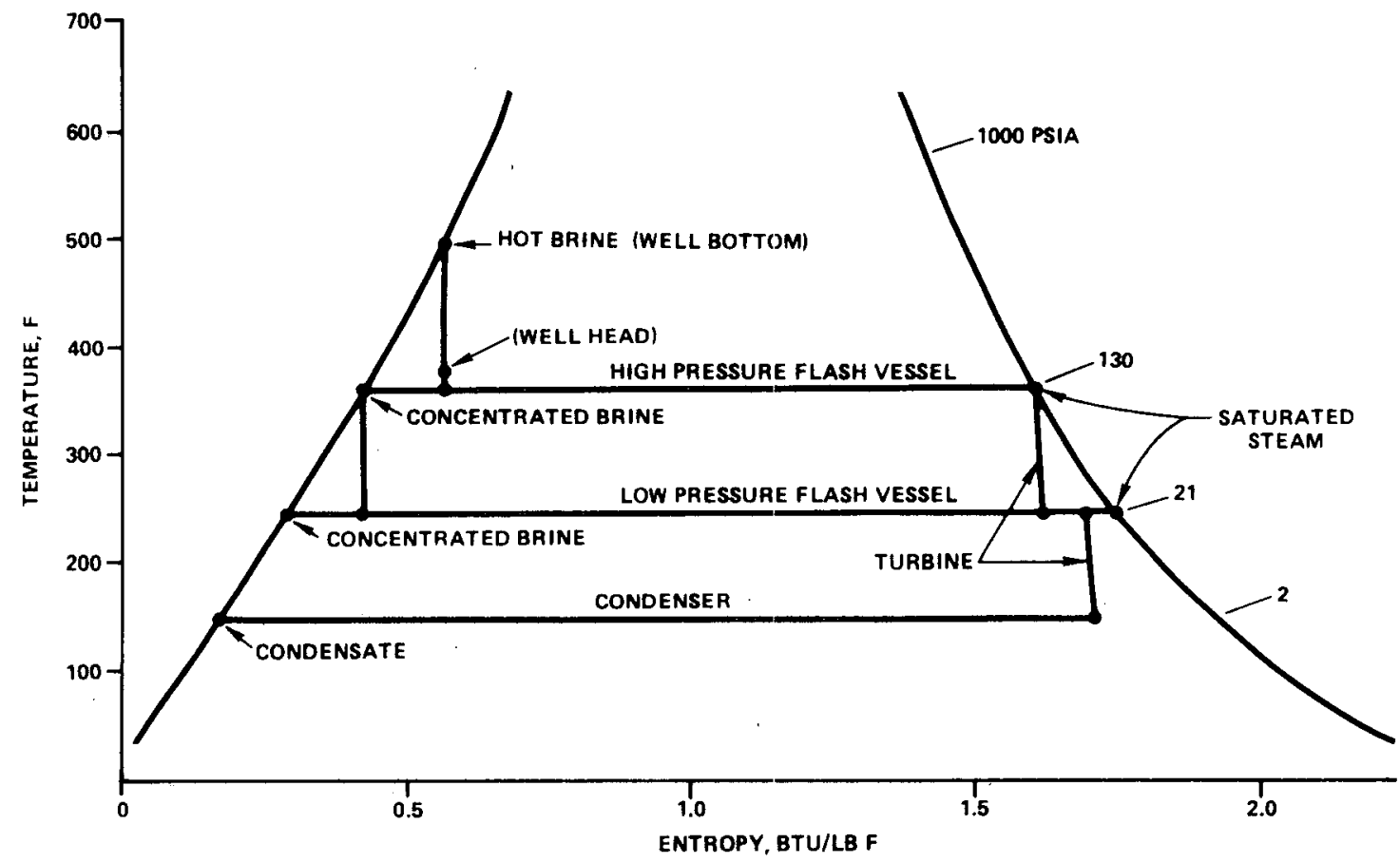

FIGURE 4 - 1 DUAL FLASH ENERGY CONVERSION PROCESS CYCLE DIAGRAM (NO MINIMUM INJECTION TEMPERATURE LIMIT) 


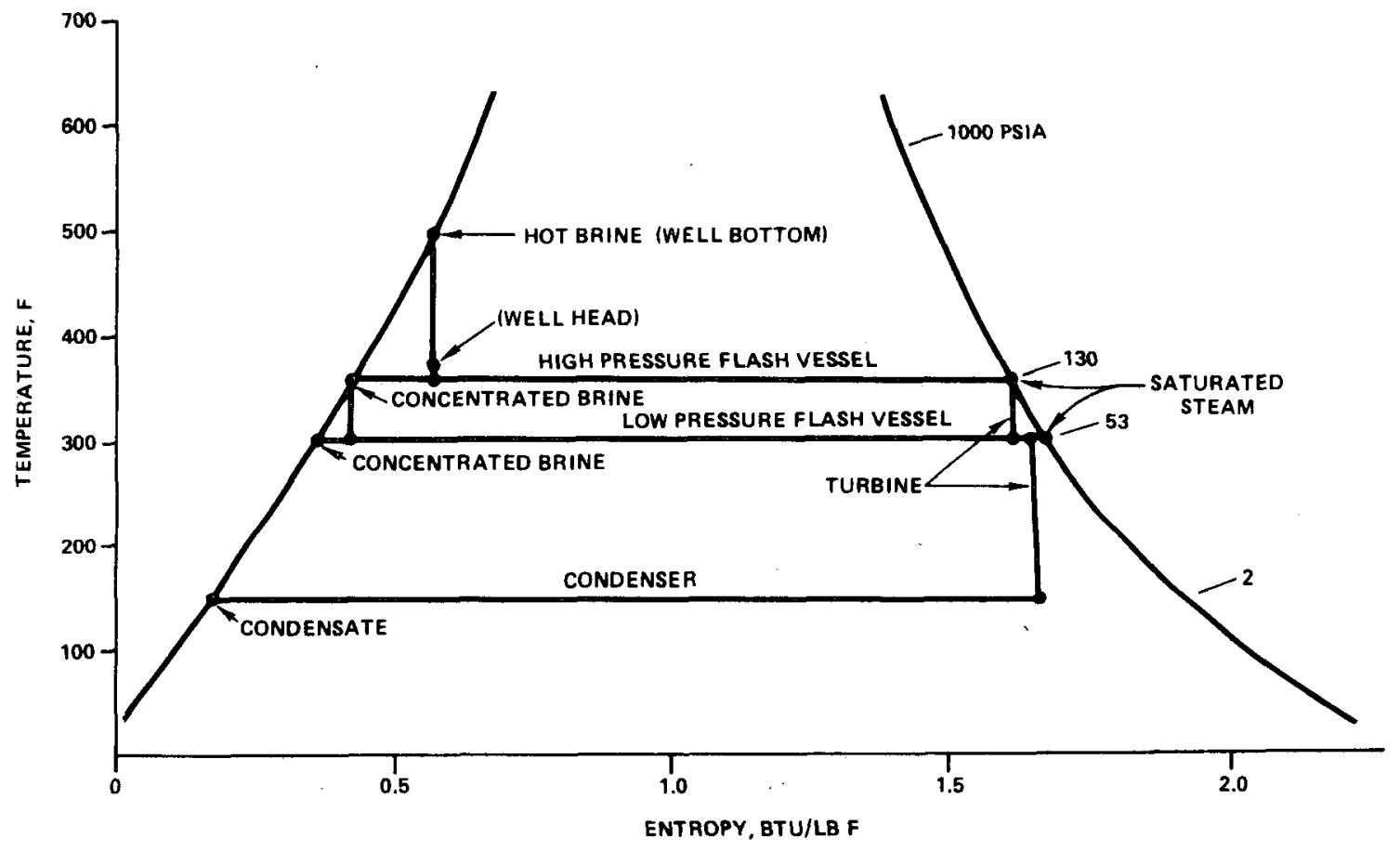

FIGURE 4 - 2 DUAL FLASH ENERGY CONVERSION CYCLE DIAGRAM (30OF MINIMUM INJECTION TEMPERATURE LIMIT) 
well head pressure of 164.7 psia and the first-stage pressure of 130 psia. This pressure difference is required to handle the pressure drops encountered in the brine production lines and control valves. Hence, first-stage pressure cannot be increased further without significantly increasing the production line size.

Flow Diagrams. Heat and mass balances have been carried out for a net output of 50 MWe and the downhole brine temperature of 482F, which occurs at year 30. Figure 4-3 (Drawing $M-100-A$ ) shows the major equipment, the associated flow rates, and thermodynamic conditions for the case of no minimum injection temperature. Figure 4-4 (Drawing $M-100-B$ ) shows the same for the case of $300 \mathrm{~F}$ minimum injection temperature. The heat and mass balance is not significantly affected by the acidification of the brine to minimize the scaling in the power plant equipment.

Plant Performance. Table 4-1 shows the performance parameters for the cases studied. The effect of limiting the brine injection temperature to $300 \mathrm{~F}$ results in an approximately 8 percent decrease in specific net output. The turbine-generator performance is based on technical and commercial information obtained from four vendors; Elliott Company. General Electric Company, Mitsubishi International Corp.. and Toshiba International corp. Both the primary and secondary isentropic expansion efficiencies of the turbine, as obtained from the vendors, are reasonably close (within 3 percent variation), and overall efficiencies are within a variation of 2 percent. The 
TABLE 4-1

PLANT PERFORMANCE PARAMETERS

50 MWe (NET) DUAL FLASH ENERGY CONVERSION

SALTON SEA KGRA, NILAND, CALIFORNIA

\begin{tabular}{|c|c|c|c|c|}
\hline & \multicolumn{2}{|c|}{$\begin{array}{l}\text { No Min. Injection } \\
\text { Temperature Limit }\end{array}$} & \multicolumn{2}{|c|}{$\begin{array}{c}\text { 300F Min. Injection } \\
\text { Temperature Limit }\end{array}$} \\
\hline & $\begin{array}{c}\text { Unmodified } \\
\text { Brine }\end{array}$ & $\begin{array}{l}\text { Acidified } \\
\text { Brine }\end{array}$ & $\begin{array}{l}\text { Unmodifed } \\
\text { Brine }\end{array}$ & $\begin{array}{l}\text { Acidified } \\
\text { Brine }\end{array}$ \\
\hline Net Electric Power Output, $\mathrm{kW}$ & 50,000 & 50,000 & 50,000 & 50,000 \\
\hline Auxiliary Power, $\mathrm{kW}$ & 6,610 & 6,610 & 7,110 & 7,110 \\
\hline Gross Electric Power Output, $\mathrm{kW}$ & 56,610 & 56,610 & 57,110 & 57,110 \\
\hline Brine Flow Rate, $10^{6} 1 \mathrm{~b} / \mathrm{hr}$ & 5.62 & 5.62 & 6.09 & 6.09 \\
\hline Down Hole Temperature, F & 482 & 482 & 482 & 482 \\
\hline Specific Net Output, Wh/1b Brine & 8.897 & 8.897 & 8.207 & 8.207 \\
\hline Net Brine Rate, lb Brine/kWh & 112.39 & 112.39 & 121.85 & 121.85 \\
\hline Turbine Generator Efficiencies, \% & & & & \\
\hline Isentropic Expansion, Primary & 81.60 & 81.60 & 81.60 & 81.60 \\
\hline Isentropic Expansion, Secondary & 79.08 & 79.08 & 79.08 & 79.08 \\
\hline Mechanical & 99.10 & 99.10 & 99.10 & 99.10 \\
\hline Electrical & 98.30 & 98.30 & 98.30 & 98.30 \\
\hline Capacity Factor, \% & $\begin{array}{l}\text { a) } 85^{(1)} \\
\text { b) } 71\end{array}$ & 85 & 71 & 71 \\
\hline
\end{tabular}

Note: (1) $85 \%$ capacity factor corresponds to three $50 \%$ capacity flash vessel trains. (Redundant Flash Vessel Case) $71 \%$ capacity factor corresponds to two $50 \%$ capacity flash vessel trains. (No Redundant Flash Vessel Case) 


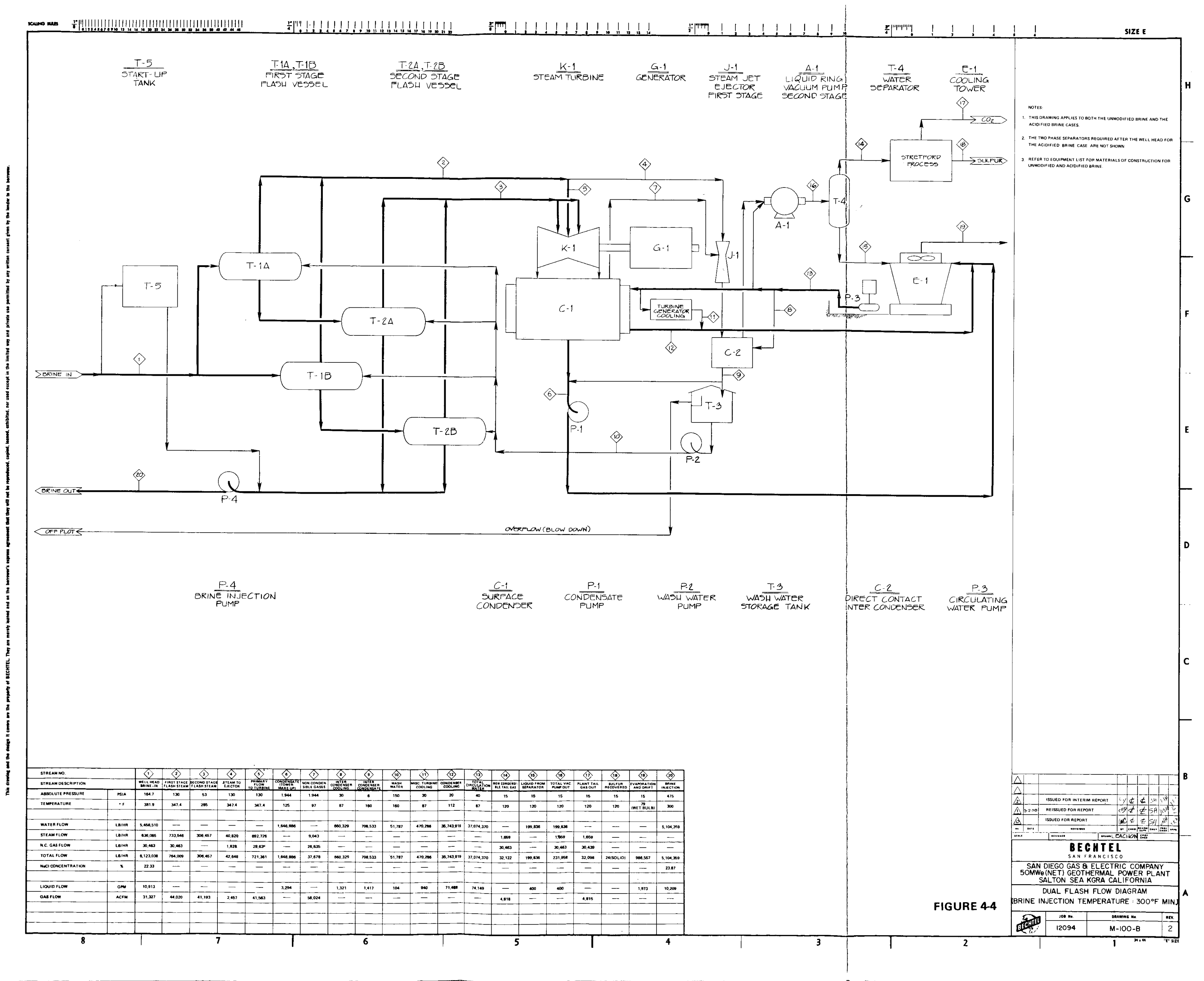


efficiencies furnished by Toshiba have been used in the calculation of heat and mass balance, since they fall close to the median of the four vendors' values. For the purposes of this study. the same secondary isentropic expansion efficiency has been used for both no minimum injection temperature and $300 \mathrm{~F}$ minimum temperature cases.

Auxiliary Power Requirement. Table 4-2 shows the electrical load required for equipment associated with generation of 50 MWe (net). Load estimates shown in the table correspond to flows indicated on the appropriate flow diagrams (Drawings $M-100-A$ and $M-100-B)$

Well schedule. Since the reservoir temperature has been assumed to decay uniformly by $18 \mathrm{~F}$ over 30 years, brine required will increase linearly from the beginning to the end of plant life at year 30. Further, the production of brine per well is assumed to decrease linearly from $400,000 \mathrm{lb} / \mathrm{hr}$ at the beginning to 300,000 lb/hr at year 30. The injection flow rate per well is assumed to remain constant at $600,000 \mathrm{lb} / \mathrm{hr}$ over the life of the plant. It is also assumed that the total number of production and injection wells required at year 30 will be twice as many as at the beginning of the plant life. The well requirement is assumed to vary linearly over the 30-year period. The number of wells thus required will exceed the theoretical requirement based on decay of downhole temperature and well flow. Table 4-3 shows the 
TABLE $\quad 4-2$

POWER PLANT AUXILIARY LOADS ${ }^{(1)}$

50 MWe (NET) DUAL FLASH ENERGY CONVERSION

SALTON SEA KGRA, NILAND, CALIFORNIA

\begin{tabular}{|lc|c|c|}
\hline & & $\begin{array}{c}\text { Injection Temperature } \\
\text { No. Min. Limit }\end{array}$ & $\begin{array}{c}\text { Injection Temperature } \\
\text { 300F Min. Limit }\end{array}$ \\
\hline Circulating Water Pumps & $(\mathrm{kW})$ & 2,190 & 1,830 \\
Injection Pumps & $(\mathrm{kW})$ & 2,550 & 3,470 \\
Vacuum Pumps & $(\mathrm{kW})$ & 740 & 810 \\
Cooling Tower Fans & $(\mathrm{kW})$ & 980 & 850 \\
Miscellaneous Loads & $(\mathrm{kW})$ & 150 & 150 \\
Total Auxiliary Load & $(\mathrm{kW})$ & 6,610 & 7,110 \\
Power Generated, Gross & $(\mathrm{kW})$ & 56,610 & 57,710 \\
& & & 50,000 \\
\hline
\end{tabular}

Note: (1)Operating load at nominal flow conditions 
TABLE $4-3$

WELL SCHEDULE

50 MWe (NET) DUAL FLASH ENERGY CONVERSION

SALTON SEA KGRA, NILAND, CALIFORNIA

\begin{tabular}{|c|c|c|}
\hline \multirow{2}{*}{$\begin{array}{c}\text { Number of } \\
\text { Wells Required }\end{array}$} & \multicolumn{2}{|c|}{ Years from Start of Operation } \\
\hline & $\begin{array}{c}\text { Injection Temperature } \\
\text { No Min. Limit }\end{array}$ & $\begin{array}{c}\text { Injection Temperature } \\
\text { 300F Min. Limit }\end{array}$ \\
\hline $\begin{array}{l}\text { Production Wells } \\
16 \\
17 \\
18 \\
19 \\
20 \\
21 \\
22 \\
23 \\
24 \\
25 \\
26 \\
27 \\
28 \\
29 \\
30 \\
31 \\
32 \\
33 \\
34\end{array}$ & $\begin{array}{r}\text { Start } \\
1.85 \\
3.75 \\
5.60 \\
7.50 \\
9.35 \\
11.25 \\
13.10 \\
15.00 \\
16.85 \\
18.75 \\
20.60 \\
22.50 \\
24.35 \\
26.25 \\
28.10 \\
30.00 \\
- \\
-\end{array}$ & $\begin{array}{c}- \\
\text { Start } \\
1.76 \\
3.52 \\
5.28 \\
7.04 \\
8.80 \\
10.56 \\
12.32 \\
14.12 \\
15.88 \\
17.64 \\
19.40 \\
21.16 \\
22.92 \\
24.68 \\
26.44 \\
28.20 \\
30.00\end{array}$ \\
\hline $\begin{array}{l}\text { Injection Wel1s } \\
\qquad \begin{array}{c}7 \\
8 \\
9 \\
10 \\
11 \\
12 \\
13 \\
14 \\
15 \\
16\end{array}\end{array}$ & $\begin{array}{r}\text { Start } \\
4.28 \\
8.56 \\
12.84 \\
17.12 \\
21.40 \\
25.68 \\
30.00 \\
- \\
-\end{array}$ & $\begin{array}{r}- \\
\text { Start } \\
3.75 \\
7.50 \\
11.25 \\
15.00 \\
18.75 \\
22.50 \\
26.25 \\
30.00\end{array}$ \\
\hline
\end{tabular}


number of production and injection wells reguired to meet these criteria.

4. 1. 4 Power Plant Facilities

The major facilities in the power plant are the flash vessels, turbine building, cooling water system, stretford process, settling pond, injection pumps, and the switchyard. For the 300F minimum injection temperature case, no settling pond is required. Figure 4-5 (Drawing C-100-A1) is a site and plot plan of the facilities for the case of no minimum injection temperature with unmodified brine used in the power plant. This particular drawing shows three 50 percent capacity trains of flash vessels. Figure 4-6 (Drawing $C-100-A 2$ ) is a site and plot plan for the case of no minimum injection temperature with acidified brine in the power plant. The site plans indicate the location of the power plant in relation to production and injection islands. All facilities located inside the fence are part of the power plant. and all other facilities outside the fence are part of the well field. A single building is provided to house the turbinegenerator with its accessories, condenser, vacuum system, electrical room, control room, office, and other miscellaneous facilities. All other major facilities are located outdoors.

Elash Vessels. Brine from the production wells is transported in a 36-inch-diameter main header to the power plant. Three 30-inch-diameter branches connect the header to the three firststage 50 percent capacity horizontal flash vessels. The flashed 


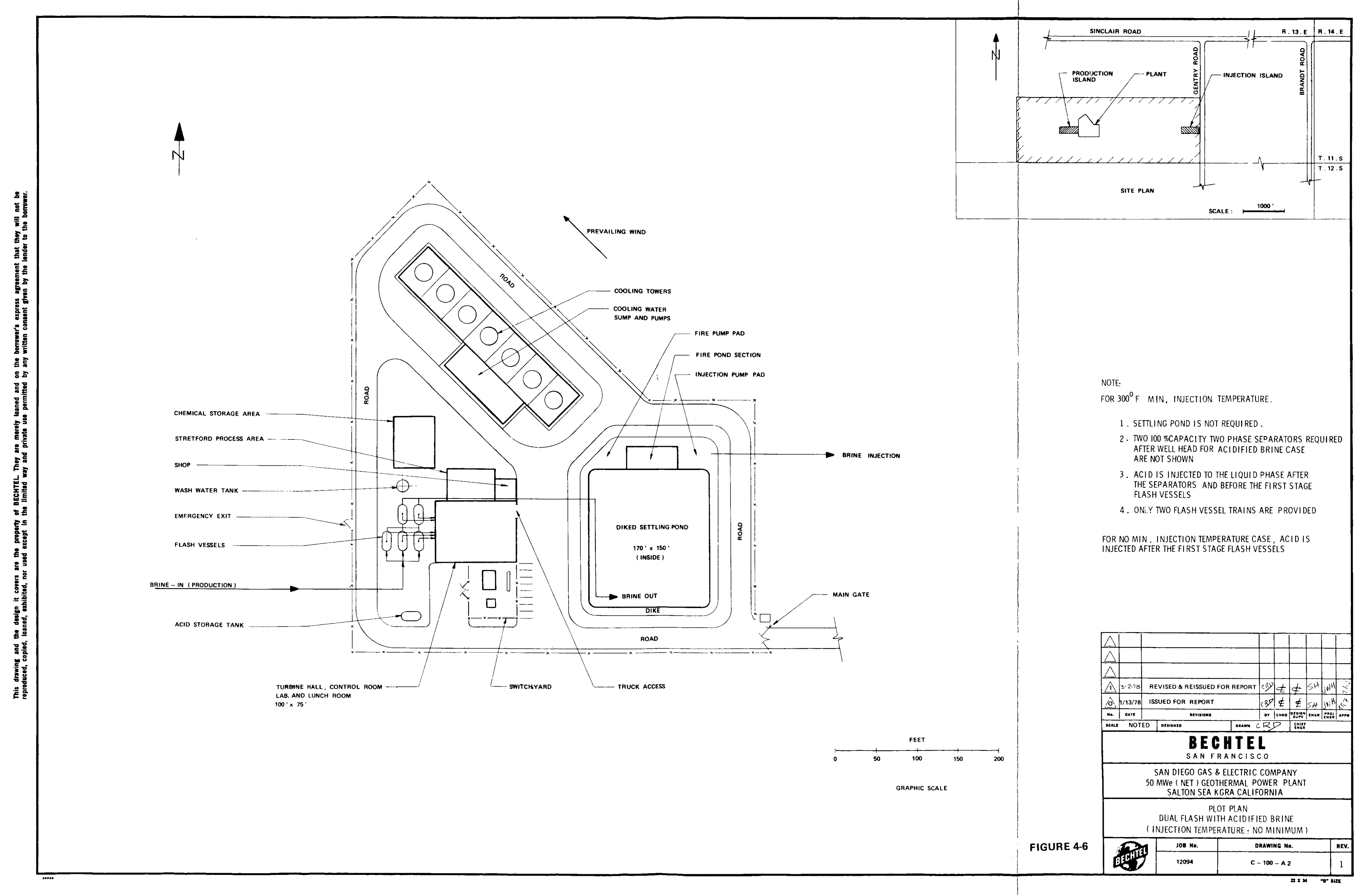


steam from each vessel is then transported in three separate 24-inch-diameter steam supply lines to the turbine high pressure inlets. The three 50 percent capacity flash vessels enable the turbine to be on line at 100 percent load while one of the flash vessels is being cleaned. Since the acid is assumed to be injected after the first-stage flash, this arrangement is used for both the unmodified and acidified brine cases.

For the unmodified brine case with redundant flash vessels (Figure 4-5), three separate 30-inch-diameter lines carry brine in parallel from the first-stage flash vessels to three second-stage 50 percent capacity horizontal flash vessels. As with the first-stage flash vessels, the use of three 50 percent capacity vessels enables the turbine to be on line at 100 percent load when one of the flash vessels is being cleaned. The flashed steam from each second-stage vessel is transported to the turbine low pressure inlets in three separate 33-inch-diameter pipes for the no minimum injection temperature case. In those cases where the brine is acidified before the second-stage flash, the scaling tendency is minimized and only two second-stage flash vessels are provided as shown in Figure 4-6. Unmodified brine from the second-stage flash vessel, in the no minimum injection temperature cases, is drained to the settling pond in three separate 24-inch-diameter pipes (Figure 4-5). Three separate drain lines enable the on-line cleaning of one 50 percent brine handing train. Only one 30-inch-diameter drain pipe is provided for the acidified brine case (Figure 4-6), since it is assumed that the power plant brine system does not scale up. 
If only two 50 percent capacity flash vessel trains are provided, the plant will be shut down while scale cleaning is being carried out for the unmodified brine case. This will drastically reduce the plant availability. This effect has been investigated, and the results are reported in terms of both plant availability and costs in section 4.2 .

The effect of acidification before the first-stage flash has also been studied. Work by LLL has determined that acidification of two-phase brine is not effective because a disproportionate amount of acid is picked up by the vapor phase. The solution to this problem requires two 100 percent capacity phase separators ahead of the first-stage flash vessels, so that the acid can be injected into the liquid phase. Downstream of the two phase separators, only two 50 percent capacity flash vessels are provided for both first- and second-stage flashes. Scaling will be limited to only the two phase separators, and 100 percent redundancy enables the plant to be on line while the scale removal is taking place. This arrangement has been evaluated and reported for the $300 \mathrm{~F}$ minimum injection temperature cases.

Figure 4-7 shows a typical section of a horizontal flash vessel. The horizontal baffle plate located above the flashing brine forces the steam to lose most of the droplets. Material carryover in the steam is trapped in the mist eliminator, which is continuously washed from below to keep it from clogging. The steam is sprayed with condensate as it exits the first mist eliminator, and the second mist eliminator is provided to clean 


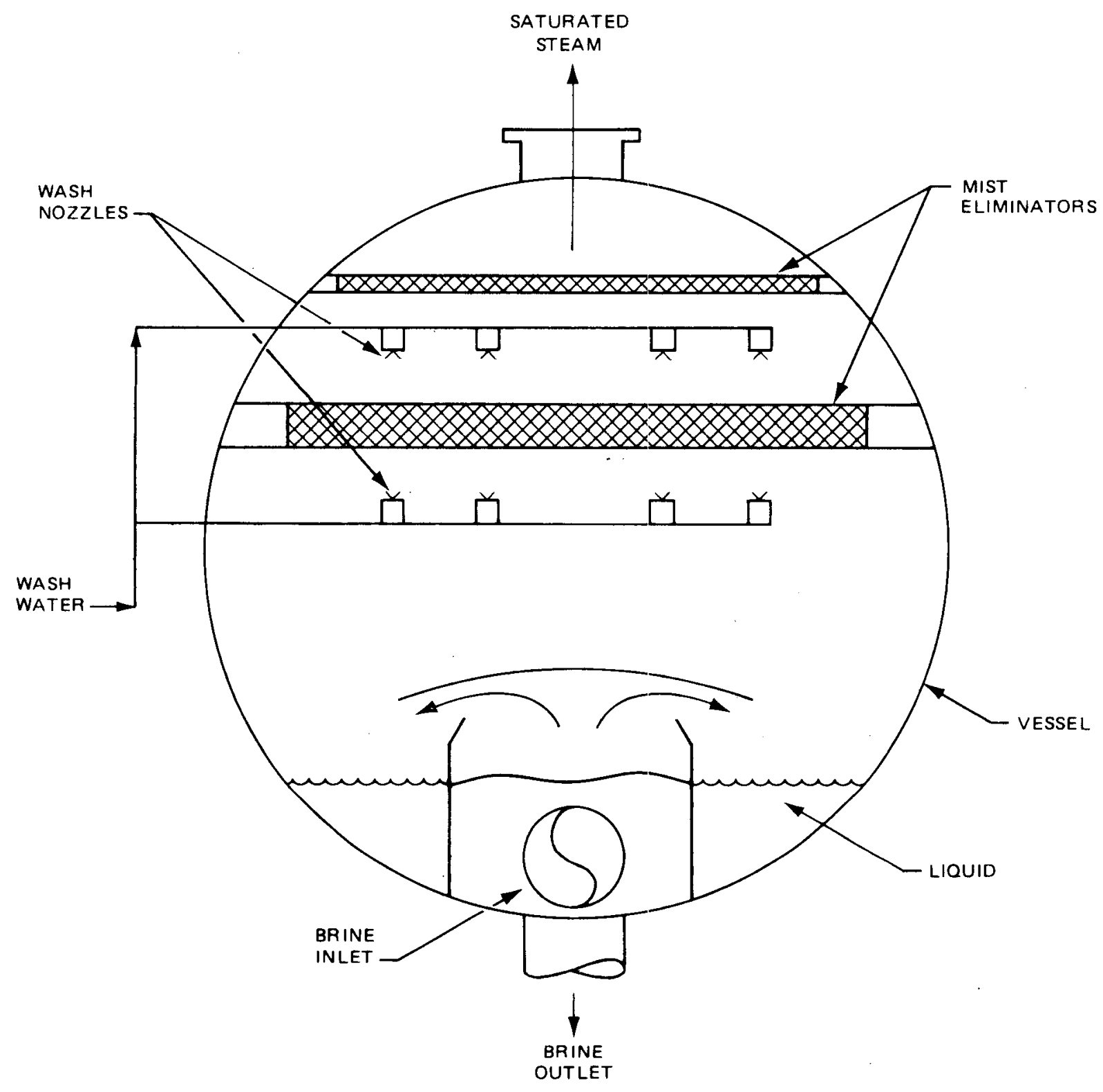

SECTION VIEW

FIGURE 4 - 7 FLASH VESSEL WITH MIST ELIMINATORS 
the steam one final time. The steam from the flash vessel is in a dry saturated condition and contains a minimum amount of carryover.

Turbine Building. The turbine building houses the turbine-generator and condenser and contains the electrical equipment room and control room. The turbine-generator is a dual flow axial type with a direct coupled hydrogen-cooled generator running at $3600 \mathrm{rpm}$. The two-pass surface condenser is located below the steam turbine. The noncondensible gases are evacuated by two 50 percent capacity first-stage ejectors, which get their motive steam from the first-stage flash vessels. Steam in the compressed mixture is condensed in a direct contact intercondenser. The second-stage evacuation equipment consists of two 50 percent capacity liquid ring pumps and moisture separators. The noncondensible gases from the separators are carried to the stretford process system in a 12-inch-diameter carbon steel pipe. The condensate from the main condenser and intercondenser is used for steam scrubbing and cooling tower makeup.

Space is provided in the turbine building for the plant and instrument air compressor, office, and laboratory. The overall size of the building is 100 feet long. 75 feet wide, and 70 feet high.

cooling water system. The cooling water system consists of a seven-cell mechanical draft, cross flow type cooling tower, with 
two 50 percent capacity circulating water pumps. The 48-inch-diameter cooling water supply and return lines are buried between the cooling tower and turbine building. The system is designed to supply cold water to the condensers at $87 \mathrm{~F}$. The blowdown from the system is pumped to the salton sea. The overall size of the seven-cell cooling tower is 69 feet wide, 253 feet long, and 60 feet high.

settling Pond. For no minimum temperature injection cases, the spent brine from the flash vessel has suspended solids that tend to clog up the injection well. Hence, a settling pond is provided to take out most of these suspended solids. The spent brine from the second-stage flash vessel flows to the 170 by 150 foot (inside dimensions) diked pond, which provides approximately a 2-hour retention time. The pond is lined with 3 -inch thick concrete and 0.030 -inch plastic sheet. If the brine was acidified in the plant, it is neutralized by injecting caustic to the brine prior to the pond. The sludge from the bottom of the pond is pumped into a solid bowl centrifuge where dewatering takes place. The concentrated sludge, with 50 percent water, is then ready for hauling to disposal.

The settling pond is not required for the $300 \mathrm{~F}$ minimum injection temperature case.

Injection pumps. Two 100 percent capacity vertical turbine barrel type pumps are provided. Since the injection pump has been found to be the critical item, 100 percent redundancy has 
been provided. The pump discharge connects to a 24-inch-diameter. 1.25-inch wall thickness carbon steel pipe. which carrys the brine to the injection island. The pipe suction is either from the pond for the no minimum injection temperature case or from the second-stage flash vessel for the $300 \mathrm{~F}$ minimum injection temperature case. The materials of construction for the pumps are 316 stainless steel.

Hydrogen sulfide Abatement system. The noncondensible gases are processed for recovery of sulfur. The system is designed based on the patented stretford process. The system design. fabrication, and installation are based on information received from Ralph M. Parsons Company, which is a licensee. The system consists of a venturi gas scrubber, absorber, reactor tank, oxidizer tanks, oxidizer air blower. sulfur froth tank, and all necessary pumps, controls, piping, chemical storage, and all other appurtenances necessary for the process. The tail gas, after processing, consists primarily of carbon dioxide with only traces of the hydrogen sulfide, which has been stated by the vendor to be within the emission and ambient air quality requirements.

switchyard. The switchyard and transformers are located as close to the turbine building as feasible and are positioned to use the turbine building as a buffer to cooling tower mist during periods of unusual wind conditions. 
TABLE $4-4$

EQQUIPMENT LIST

50 MWe (NET) DUAL FLASH ENERGY CONVERSION

SALTON SEA KGRA, NILAND, CALIFORNIA

\begin{tabular}{|c|c|c|}
\hline \multicolumn{3}{|c|}{ No Minimum Injection Temperature Limit Case } \\
\hline Equipment & \multicolumn{2}{|r|}{ Description } \\
\hline $\begin{array}{c}\text { First-Stage Flash Vesse } 1 \\
\mathrm{~T}-1 \mathrm{~A}, \mathrm{~T}-1 \mathrm{~B}, \text { and } \mathrm{T}-1 \mathrm{C}\end{array}$ & $\begin{array}{l}\text { Quantity: } \\
\text { Type: } \\
\text { Size: } \\
\text { Design: } \\
\text { General: }\end{array}$ & $\begin{array}{l}\text { Three ( } 3 \text { ); two (2) for non- } \\
\text { redundant } \\
\text { Horizontal with elliptical heads } \\
10 \mathrm{ft} \mathrm{dia} 18 \mathrm{ft} \text { long } \\
175 \mathrm{psig} / 450 \mathrm{~F} \\
\text { Carbon Steel A516 Gr60 material. } \\
\text { Two layers of stainless steel } \\
\text { mist eliminator, stainless steel } \\
\text { spray nozzles, and } 3 \text { in. insu- } \\
\text { lation. Shell thickness: } 3 / 4 \text { in. } \\
\text { plus } 5 / 8 \text { in. corrosion allowance. }\end{array}$ \\
\hline $\begin{array}{c}\text { Second-Stage Flash Vesse } 1 \\
\mathrm{~T}-2 \mathrm{~A}, \mathrm{~T}-2 \mathrm{~B} \text {, and } \mathrm{T}-2 \mathrm{C}\end{array}$ & $\begin{array}{l}\text { Quantity: } \\
\text { Type: } \\
\text { Size: } \\
\text { Design: } \\
\text { General: }\end{array}$ & $\begin{array}{l}\text { Three ( } 3 \text { ); two (2) for non- } \\
\text { redundant } \\
\text { Horizonta1 with e1liptical heads } \\
10 \mathrm{ft} \text { dia. } x 22 \mathrm{ft} \text { long } \\
50 \mathrm{psig} / 300 \mathrm{~F} \\
\text { Carbon steel A516 Gr60 material. } \\
\text { Two layers of stainless steel } \\
\text { mist eliminators, stainless } \\
\text { steel nozzles, and } 2 \mathrm{in.} \text { insu- } \\
\text { lation. Shell thickness: } 1 / 2 \text { in. } \\
\text { plus } 5 / 8 \text { in. corrosion a1lowance. }\end{array}$ \\
\hline $\begin{array}{l}\text { Wash Water Storage Tank } \\
\text { T-3 }\end{array}$ & $\begin{array}{l}\text { Quantity: } \\
\text { Type: } \\
\text { Size: } \\
\text { Design: } \\
\text { General: }\end{array}$ & $\begin{array}{l}\text { One }(1) \\
\text { Vertical covered } \\
12 \mathrm{ft} \text { dia. } x 15 \mathrm{ft} \text { high } \\
\text { Atmospheric pressure } / 212 \mathrm{~F} \\
\text { Epoxy lined carbon steel with } \\
\text { cover. }\end{array}$ \\
\hline $\begin{array}{l}\text { Steam Turbine } \\
\mathrm{K}-1\end{array}$ & $\begin{array}{l}\text { Quantity: } \\
\text { Type: } \\
\text { Rating: } \\
\text { Inlet: }\end{array}$ & $\begin{array}{l}\text { One ( } 1 \text { ) } \\
\text { Dual admission, double axial flow } \\
57,000 \mathrm{kWe} / 3600 \mathrm{rpm} \\
\text { Steam at } 130 \text { psia and } 21 \text { psia } \\
\text { both dry saturated. }\end{array}$ \\
\hline
\end{tabular}


TABLE 4-4 (Continued)

\begin{tabular}{|c|c|c|}
\hline Equipment & & Description \\
\hline $\begin{array}{l}\text { Steam Turbine } \\
\text { (Continued) }\end{array}$ & $\begin{array}{l}\text { Exhaust: } \\
\text { General: }\end{array}$ & $\begin{array}{l}4 \text { in. hg abs. } \\
\text { Inclusive of inlet stop and con- } \\
\text { trol valves, steam strainers, } \\
\text { moisture separators, check valves, } \\
\text { gland seal system, control system, } \\
\text { lub oil system, hydrogen system, } \\
\text { and panel. }\end{array}$ \\
\hline $\begin{array}{l}\text { Generator } \\
\text { G-1 }\end{array}$ & $\begin{array}{l}\text { Quantity: } \\
\text { Type: } \\
\text { Rating: } \\
\text { General: }\end{array}$ & $\begin{array}{l}\text { One }(1) \\
\text { Hydrogen cooled, three-phase direct } \\
\text { coupled to turbine } \\
67,500 \mathrm{kVA}, \mathrm{PF} 0.85 \text { lagging } \\
13.8 \mathrm{kV} \text { rated, } 60 \mathrm{~Hz} \text {, class } \mathrm{B} \\
\text { insulation, static excitation, } \\
\text { short circuit ratio } 0.58\end{array}$ \\
\hline $\begin{array}{l}\text { Condenser } \\
\text { C-1 }\end{array}$ & $\begin{array}{l}\text { Quantity: } \\
\text { Type: } \\
\text { Rating: } \\
\text { General: }\end{array}$ & $\begin{array}{l}\text { One ( } 1 \text { ) } \\
\text { Two pass, surface } \\
4 \mathrm{in.} \mathrm{hg} \mathrm{abs.} 114,000 \mathrm{ft}^{2} \text { area } \\
22 \mathrm{ft} \times 22 \mathrm{ft} \times 46 \mathrm{ft} \text { long, } 316 \\
\text { stainless steel tubes and } 316 \\
\text { clad carbon steel internal, } \\
\text { epoxy lined carbon steel water } \\
\text { boxes. }\end{array}$ \\
\hline $\begin{array}{l}\text { Steam Jet Ejector, First } \\
\text { Stage } \\
\text { J-1A and J-1B }\end{array}$ & $\begin{array}{l}\text { Quantity: } \\
\text { General: }\end{array}$ & $\begin{array}{l}\text { Two (2) } 50 \% \text { capacity } \\
316 \text { stainless steel type con- } \\
\text { struction, } 40,000 \mathrm{lb} / \mathrm{hr} \text { total } \\
\text { noncondensible gases, } 60,000 \\
\text { la/hr motive steam at } 100 \mathrm{psig} \\
\text { saturated. }\end{array}$ \\
\hline $\begin{array}{l}\text { Direct Contact } \\
\text { Intercondenser } \\
\quad \mathrm{C}-2\end{array}$ & $\begin{array}{l}\text { Quantity: } \\
\text { General: }\end{array}$ & $\begin{array}{l}\text { One ( } 1 \text { ) } \\
316 \text { stainless steel clad carbon } \\
\text { steel shell with } 316 \text { stainless } \\
\text { steel internals, capable of } \\
\text { condensing } 60,000 \mathrm{lb} / \mathrm{hr} \text { steam at } \\
\text { approximately } 6 \text { psia. }\end{array}$ \\
\hline
\end{tabular}


TABLE 4-4 (Continued)

\begin{tabular}{|c|c|c|}
\hline Equipment & & Description \\
\hline $\begin{array}{l}\text { Liquid Ring Vacuum Pump, } \\
\text { Second Stage. } \\
\text { A-1A and A-1B }\end{array}$ & $\begin{array}{l}\text { Quantity: } \\
\text { General: }\end{array}$ & $\begin{array}{l}\text { Two (2) } 50 \% \text { capacity } \\
\text { Single-stage positive displace- } \\
\text { ment vacuum pump with liquid } \\
\text { seal enclosed rotor; compression } \\
\text { ratio }=2: 5 \text {, stainless stee } 1 \\
\text { internals. } 30,0001 \mathrm{~b} / \mathrm{hr} \text { gas } \\
\text { flow. } 600 \mathrm{hp} \text { motor with speed } \\
\text { reducer. }\end{array}$ \\
\hline $\begin{array}{l}\text { Water Separator } \\
\mathrm{T}-4 \mathrm{~A} \text { and } \mathrm{T}-4 \mathrm{~B}\end{array}$ & $\begin{array}{l}\text { Quantity: } \\
\text { Genera1: }\end{array}$ & $\begin{array}{l}\text { Two (2) } \\
\text { Each } 316 \text { stainless steel vessel } \\
4 \mathrm{ft} \text { dia. } \times 6 \mathrm{ft} \text { high for dis- } \\
\text { charge of vacuum pump with level } \\
\text { indicator and controller. }\end{array}$ \\
\hline $\mathrm{H}_{2} \mathrm{~S}$ Abatement System & $\begin{array}{l}\text { Quantity: } \\
\text { General: }\end{array}$ & $\begin{array}{l}\text { Lot } \\
\text { Consists of } 14 \text { in. dia. x } 20 \mathrm{ft} \\
\text { high venturi scrubber, } 7 \mathrm{ft} \text { dia. } \\
\text { x } 40 \mathrm{ft} \text { high absorber, } 3 \text { ft dia. } \\
\text { x } 13 \mathrm{ft} \text { high oxidizer tank, } 8 \mathrm{ft} \\
\text { dia. x } 13 \mathrm{ft} \text { high froth/balance } \\
\text { tank, one }+ \text { one spare, recycle } \\
\text { pump } 550 \text { gpm @ } 20 \text { psi one }+ \text { one } \\
\text { spare, solution circular pump } \\
105 \text { gpm @ } 70 \text { psi } 6 \text { in. solid bow1 } \\
\text { centrifuge, feed pump } 10 \text { gpm } \\
20 \text { psi, } 5 \text { hp turboaerator. Total } \\
\text { installed hp } 60 \text {; operating hp } 30 .\end{array}$ \\
\hline $\begin{array}{l}\text { Cooling Tower } \\
\text { E-1A through } 1 \mathrm{G}\end{array}$ & $\begin{array}{l}\text { Quantity: } \\
\text { Type: } \\
\text { Genera1: }\end{array}$ & $\begin{array}{l}\text { Seven ( } 7 \text { ) cells } \\
\text { Mechanical draft crossflow } \\
69 \mathrm{ft} \text { wide } \times 253 \mathrm{ft} \text { long } \times 60 \mathrm{ft} \\
\text { high; } 79 \mathrm{~F} \text { wet bulb with } 8^{\circ} \mathrm{F} \\
\text { approach. Fan hp } 200 \text { each cell. }\end{array}$ \\
\hline $\begin{array}{l}\text { Condensate Pumps } \\
\mathrm{P}-1 \mathrm{~A} \text { and } \mathrm{P}-1 \mathrm{~B}\end{array}$ & $\begin{array}{l}\text { Quantity: } \\
\text { Type: } \\
\text { General: }\end{array}$ & $\begin{array}{l}\text { Two (2) } 50 \% \text { capacity } \\
\text { Vertical multistage turbine } \\
125 \mathrm{~F} \text { suction; } 1800 \mathrm{gpm} \text { at } 80 \mathrm{ft} \\
\text { TDH, } 316 \text { stainless steel internals. } \\
50 \mathrm{hp} \text { motor. }\end{array}$ \\
\hline
\end{tabular}


TABLE 4-4 (Continued)

\begin{tabular}{|c|c|c|}
\hline Equipment & & Description. \\
\hline $\begin{array}{l}\text { Wash Water Pump } \\
\quad \mathrm{P}-2\end{array}$ & $\begin{array}{l}\text { Quantity: } \\
\text { General: }\end{array}$ & $\begin{array}{l}\text { One (1) } \\
\text { Horizontal centrifugal } 160 \mathrm{~F} \\
\text { suction; } 125 \text { gpm @ } 350 \mathrm{ft} \mathrm{TDH} \\
\text { with } 15 \mathrm{hp} \text { motor. }\end{array}$ \\
\hline $\begin{array}{l}\text { Circulating Water Pump } \\
\text { P } 3-A \text { and } P-3 B\end{array}$ & $\begin{array}{l}\text { Quantity: } \\
\text { Type: } \\
\text { General: }\end{array}$ & $\begin{array}{l}\text { Two (2) } 50 \% \text { capacity } \\
\text { Vertical wet pit mixed flow } \\
43,000 \text { pgm at } 100 \mathrm{ft} \text { TDH, } 316 \\
\text { stainless steel with carbon } \\
\text { steel stand and sole plate. } \\
1600 \mathrm{hp} \text { motor. }\end{array}$ \\
\hline $\begin{array}{l}\text { Injection Pump } \\
\mathrm{P}-4 \mathrm{~A} \text { and } \mathrm{P}-4 \mathrm{~B}\end{array}$ & $\begin{array}{l}\text { Quantity: } \\
\text { Type: } \\
\text { General: }\end{array}$ & $\begin{array}{l}\text { Two (2) } 100 \% \text { capacity } \\
\text { Vertical turbine barrel } \\
\text { One operating, one spare; } \\
8000 \text { gpm at } 1000 \mathrm{ft} \text { TDH, } 316 \\
\text { stainless steel. } 3600 \text { hp motor. }\end{array}$ \\
\hline $\begin{array}{l}\text { Plant Water Storage Tank } \\
\text { T-6 }\end{array}$ & $\begin{array}{l}\text { Quantity: } \\
\text { General: }\end{array}$ & $\begin{array}{l}\text { One ( } 1 \text { ) } \\
15 \mathrm{ft} \text { dia. } x 15 \mathrm{ft} \text { high carbon } \\
\text { steel covered tank with } 20,000 \\
\text { gallon approx. capacity. }\end{array}$ \\
\hline $\begin{array}{l}\text { Plant Water Supply Pump } \\
\text { P-5 }\end{array}$ & $\begin{array}{l}\text { Quantity: } \\
\text { General: }\end{array}$ & $\begin{array}{l}\text { One ( } 1 \text { ) } \\
\text { Horizontal, single stage centri- } \\
\text { fugal pump } 200 \mathrm{gpm} \text { a } 125 \mathrm{ft} \mathrm{TDH.} \\
10 \mathrm{hp} \text { motor. }\end{array}$ \\
\hline $\begin{array}{l}\text { Plant and Instrument } \\
\text { Air Compressors }\end{array}$ & $\begin{array}{l}\text { Quantity: } \\
\text { General: }\end{array}$ & $\begin{array}{l}\text { Two (2) } \\
350 \text { ACFM, } 125 \text { psig, double acting, } \\
\text { reciprocating, non-lube cylinders, } \\
\text { complete with } 100 \mathrm{hp} \mathrm{motor,} \mathrm{inter-} \\
\text { coolers, aftercoolers, moisture } \\
\text { separator, dryer, and receiver. }\end{array}$ \\
\hline Traveling Bridge Crane & $\begin{array}{l}\text { Quantity: } \\
\text { Genera1: }\end{array}$ & $\begin{array}{l}\text { One (1) } \\
60 \text { ton capacity top riding, double } \\
\text { girder bridge crane, cab operated, } \\
\text { complete with main hoist, } 15 \text { ton } \\
\text { auxiliary hoist multiple step } \\
\text { controls. }\end{array}$ \\
\hline
\end{tabular}


TABLE 4-4 (Continued)

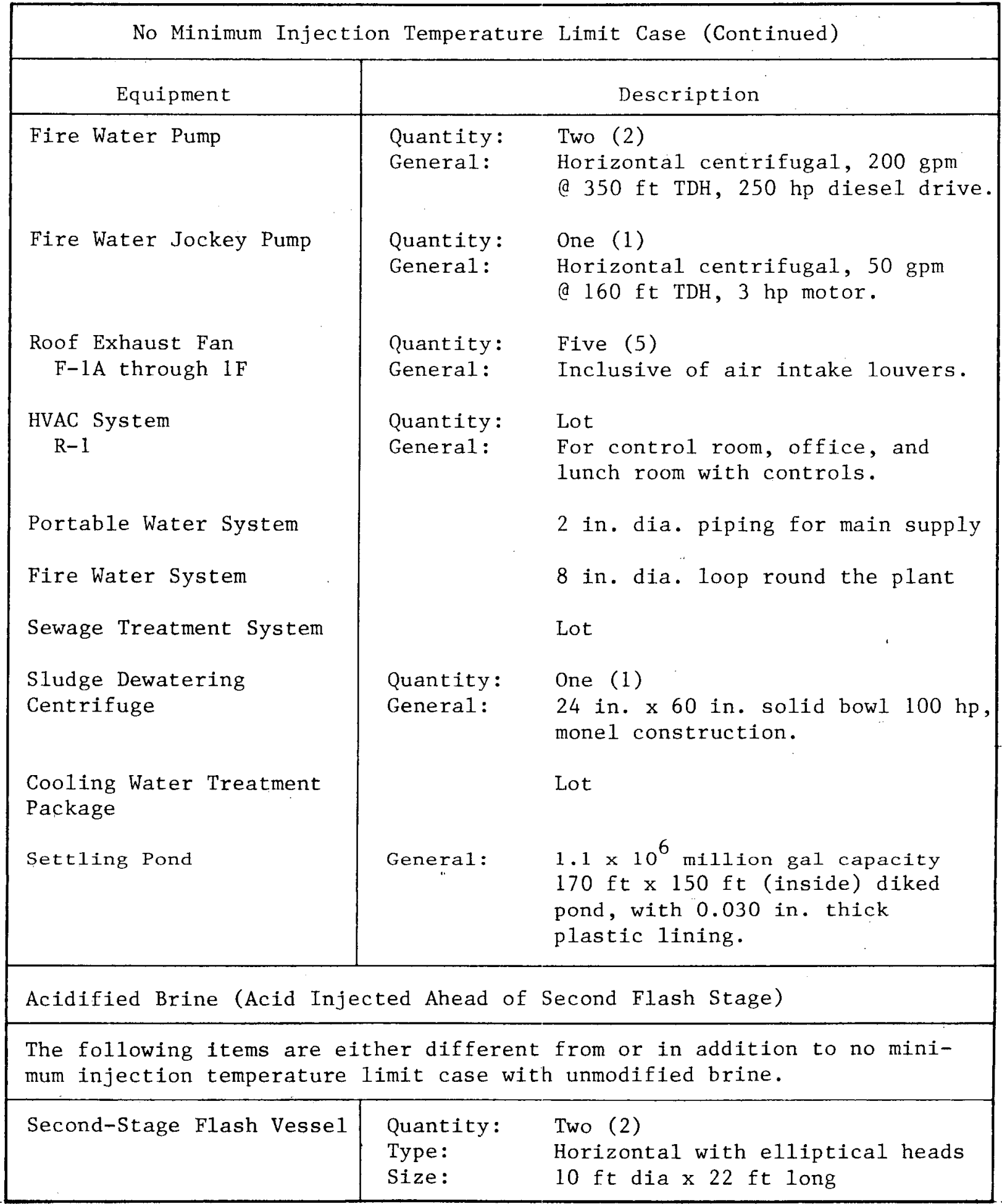


TABLE 4-4 (Continued)

\begin{tabular}{|c|c|c|}
\hline \multicolumn{3}{|c|}{ No Minimum Injection Temperature Limit Case (Continued) } \\
\hline Equipment & & Description \\
\hline $\begin{array}{l}\text { Second-Stage Flash Vessel } \\
\text { (Continued) }\end{array}$ & $\begin{array}{l}\text { Design: } \\
\text { General: }\end{array}$ & $\begin{array}{l}50 \text { psig/ } 300 \mathrm{~F} \\
1 \mathrm{Cr}, 1 / 2 \text { Mo alloy steel, two } \\
\text { layers of stainless steel spray } \\
\text { nozzles and } 2 \text { in. insulation. } \\
\text { She11 thickness: } 1 / 2 \text { in. thick } \\
\text { shell plus } 1 / 2 \text { in. corrosion } \\
\text { allowance. }\end{array}$ \\
\hline $\begin{array}{l}\text { Hydrochloric Acid Storage } \\
\text { Tank }\end{array}$ & $\begin{array}{l}\text { Quantity: } \\
\text { Genera1: }\end{array}$ & $\begin{array}{l}\text { One ( } 1) \\
12 \mathrm{ft} \text { dia } \times 20 \mathrm{ft} \text { long, horizontal } \\
\text { with elliptical heads, filament } \\
\text { wound fiber reinforced plastic } \\
\text { tank, epoxy coated carbon steel } \\
\text { saddles on lime stone base. } \\
16,000 \text { gal capacity. }\end{array}$ \\
\hline Caustic Storage Tank & $\begin{array}{l}\text { Quantity: } \\
\text { General: }\end{array}$ & $\begin{array}{l}\text { One ( } 1) \\
14 \mathrm{ft} \text { dia } \times 14 \mathrm{ft} \text { high, vertical } \\
\text { covered, carbon steel with } 100 \mathrm{ft}^{2} \\
\text { nickel heating coil }\end{array}$ \\
\hline \multicolumn{3}{|c|}{ 300F Min. Injection Temperature Limit Case } \\
\hline \multicolumn{3}{|c|}{$\begin{array}{l}\text { Unmodified Brine } \\
\text { Items are same as for no minimum limit injection temperature case with } \\
\text { unmodified brine except with the following differences. } \\
\text { - Two first-stage flash vessels ( } \mathrm{T}-1 \mathrm{~A} \text { and } \mathrm{T}-1 \mathrm{~B}) \text {; i.e., Non-Redundant Case. } \\
\text { - No brine settling pond ( } 170 \mathrm{ft} \times 150 \mathrm{ft} \text { diked) is required. } \\
\text { No solid bowl centrifuge is required. }\end{array}$} \\
\hline Equipment & & Description \\
\hline $\begin{array}{l}\text { Second-Stage Flash Vessel } \\
\mathrm{T}-2 \mathrm{~A} \text { and } \mathrm{T}-2\end{array}$ & $\begin{array}{l}\text { Quantity } \\
\text { Type: } \\
\text { Size: } \\
\text { Design: }\end{array}$ & $\begin{array}{l}\text { Two (2) } \\
\text { Horizontal with elliptical heads } \\
10 \mathrm{ft} \text { dia } \times 18 \text { ft long } \\
75 \text { psig/375F }\end{array}$ \\
\hline
\end{tabular}


TABLE 4-4 (Continued)

\begin{tabular}{|c|c|c|}
\hline Equipment & & Description \\
\hline $\begin{array}{l}\text { Second-Stage Flash Vessel } \\
\text { (Continued) }\end{array}$ & General: & $\begin{array}{l}\text { Carbon steel A516 Gr60, two layers } \\
\text { of stainless stee } 1 \text { mist eliminators, } \\
\text { stainless steel spray nozzles and } \\
2 \text { in. insulation. Shell thickness } \\
1 / 2 \text { in. plus } 5 / 8 \text { in. corrosion } \\
\text { allowance. }\end{array}$ \\
\hline $\begin{array}{l}\text { Steam Turbine } \\
\mathrm{K}-1\end{array}$ & $\begin{array}{l}\text { Quantity: } \\
\text { Type: } \\
\text { Rating: } \\
\text { Inlet: } \\
\text { General: }\end{array}$ & $\begin{array}{l}\text { One ( } 1) \\
\text { Dual admission, double axial flow } \\
57,000 \mathrm{kWe} / 3600 \mathrm{rpm} \\
\text { Steam at } 130 \mathrm{psia} \text { and } 53 \mathrm{psia}, \\
\text { both dry saturated. } \\
\text { Inclusive of inlet stop and con- } \\
\text { trol valves, steam strainers, } \\
\text { moisture separators, check valves, } \\
\text { gland seal system, control system, } \\
\text { lube oil system, hydrogen system, } \\
\text { and panel. }\end{array}$ \\
\hline $\begin{array}{c}\text { Condensate Pumps } \\
\mathrm{P}-1 \mathrm{~A} \text { and } \mathrm{P}-1 \mathrm{~B}\end{array}$ & $\begin{array}{l}\text { Quantity: } \\
\text { Type: } \\
\text { General: }\end{array}$ & $\begin{array}{l}\text { Two (2) } 50 \% \text { capacity } \\
\text { Vertical multistage turbine } \\
125 \mathrm{~F} \text { suction, } 1650 \mathrm{gpm} \text { at } 80 \mathrm{ft} \\
\text { TDH, } 316 \text { stainless steel internals, } \\
45 \mathrm{hp} \text { motor. }\end{array}$ \\
\hline Circulating Water Pump & $\begin{array}{l}\text { Quantity: } \\
\text { Type: } \\
\text { General: }\end{array}$ & $\begin{array}{l}\text { Two ( } 2) 50 \% \text { capacity } \\
\text { Vertical wet pit mixed flow } \\
38,000 \text { gpm at } 100 \mathrm{ft} \text { TDH, } 316 \\
\text { stainless steel with carbon steel } \\
\text { stand and sole plate. } 1500 \mathrm{hp} \\
\text { motor. }\end{array}$ \\
\hline Injection Pump & $\begin{array}{l}\text { Quantity: } \\
\text { Type: } \\
\text { General: }\end{array}$ & $\begin{array}{l}\text { Two (2) } 100 \% \text { capacity } \\
\text { Vertical turbine barrel. } \\
\text { One operating, one spare; } 10,500 \mathrm{gpm} \\
\text { at } 1200 \mathrm{ft} \mathrm{TDH}, 316 \text { stainless steel. } \\
4800 \mathrm{hp}\end{array}$ \\
\hline
\end{tabular}


TABLE 4-4 (Continued)

\begin{tabular}{|c|c|c|}
\hline \multicolumn{3}{|c|}{ 300F Minimum Injection Temperature Limit Case (Continued) } \\
\hline \multicolumn{3}{|c|}{ Acidified Brine (Acid Injected Ahead of First-Stage Flash) } \\
\hline \multicolumn{3}{|c|}{$\begin{array}{l}\text { The following items are either different from or in addition to 300F } \\
\text { minimum injection temperature case with unmodified brine. }\end{array}$} \\
\hline Equipment & & Description \\
\hline $\begin{array}{l}\text { First-Stage Flash Vesse } 1 \\
\text { T-1A and } \mathrm{T}-1 \mathrm{~B}\end{array}$ & $\begin{array}{l}\text { Quantity: } \\
\text { Type: } \\
\text { Size: } \\
\text { Design: } \\
\text { General: } \\
\end{array}$ & $\begin{array}{l}\text { Two (2) } \\
\text { Horizontal with elliptical heads } \\
10 \mathrm{ft} \text { dia } 18 \mathrm{ft} \text { long } \\
175 \mathrm{psig} / 450 \mathrm{~F} \\
1 \mathrm{Cr} \text { plus } 1 / 2 \text { Mo alloy steel, two } \\
\text { layers of stainless steel mist } \\
\text { eliminators, stainless steel spray } \\
\text { nozzles and } 3 \mathrm{in.} \text { insulation. } \\
\text { Shell thickness: } 7 / 8 \text { in. plus } \\
1 / 2 \text { in. corrosion allowance. }\end{array}$ \\
\hline $\begin{array}{l}\text { Second-Stage Flash Vessel } \\
\mathrm{T}-2 \mathrm{~A} \text { and } \mathrm{T}-2 \mathrm{~B}\end{array}$ & $\begin{array}{l}\text { Quantity: } \\
\text { Type: } \\
\text { Size: } \\
\text { Design: } \\
\text { General: }\end{array}$ & $\begin{array}{l}\text { Two (2) } \\
\text { Horizontal with elliptical heads } \\
10 \mathrm{ft} \text { dia } \mathrm{x} 18 \mathrm{ft} \text { long } \\
75 \mathrm{psig} / 375 \mathrm{~F} \\
1 \mathrm{Cr} \text { plus } 1 / 2 \text { Mo alloy stee } 1 \text {, two } \\
\text { layers of stainless steel mist } \\
\text { eliminators, stainless steel spray } \\
\text { nozzles and } 2 \mathrm{in} \text {. insulation. } \\
\text { Shell thickness: } 1 / 2 \text { in. plus } 1 / 2 \\
\text { in. corrosion allowance. }\end{array}$ \\
\hline $\begin{array}{l}\text { Two-Phase Separators } \\
\text { T-7A and T-7B }\end{array}$ & $\begin{array}{l}\text { Quantity: } \\
\text { Type: } \\
\text { Design: }\end{array}$ & $\begin{array}{l}\text { Two (2) } \\
12 \text { ft dia } \times 12 \mathrm{ft} \text { high with support } \\
\text { legs } \\
\text { Carbon steel, A516 Gr60 one operat- } \\
\text { ing plus one spare. She } 11 \text { thickness: } \\
7 / 8 \text { in. plus } 5 / 8 \text { in. corrosion } \\
\text { allowance. }\end{array}$ \\
\hline $\begin{array}{l}\text { Hydrochloric Acid Storage } \\
\text { Tank } \\
\quad \text { T-8 }\end{array}$ & $\begin{array}{l}\text { Quantity: } \\
\text { General: }\end{array}$ & $\begin{array}{l}\text { One (1) } \\
12 \mathrm{ft} \text { dia x } 20 \mathrm{ft} \text { long, horizontal } \\
\text { with elliptical heads, filament } \\
\text { wound fiber reinforced plastic tank, } \\
\text { epoxy coated carbon steel saddles } \\
\text { on limestone base. } 16,000 \text { gal } \\
\text { capacity. }\end{array}$ \\
\hline
\end{tabular}


TABLE 4-4 (Continued)

\begin{tabular}{|c|cc|}
\hline \multicolumn{2}{|c|}{ 300F Minimum Injection Temperature Limit Case (Continued) } \\
\hline \multicolumn{2}{|c|}{ Equipment } & \multicolumn{1}{c|}{ Description } \\
\hline $\begin{array}{l}\text { Caustic Storage Tank } \\
\text { T-9 }\end{array}$ & $\begin{array}{l}\text { Quantity: } \\
\text { General: }\end{array}$ & $\begin{array}{l}\text { One (1) } \\
14 \mathrm{ft} \mathrm{dia} \mathrm{x} 14 \mathrm{ft} \text { high, vertical } \\
\text { covered carbon steel with 100 ft }\end{array}$ \\
nickel heating coil.
\end{tabular}


Equipment List. The equipment list given in Table 4-4 shows all the major equipment required in the 50 MWe (net) power generation plant for the no minimum injection temperature and the $300 \mathrm{~F}$ injection temperature cases. The no minimum injection temperature case with unmodified brine is treated as the base case, and variations from this list are shown for the no minimum injection temperature case with acidified brine. Similarly, only changes for the $300 \mathrm{~F}$ minimum injection temperature cases from the base case are indicated.

Piping Material. Carbon steel has been assumed suitable for brine and steam pipes while handling unmodified brine. For handling acidified brine, $1 \mathrm{Cr} 1 / 2$ Mo low alloy steel has been assumed to be suitabje piping material. However, carbon steel is assumed to be a suitable piping material for handling steam flashed from the acidified brine.

\subsubsection{Well Field Facilities}

All facilities located outside the fence, as shown in Figures 4-5 and 4-6, are classified under well field facilities.

Well field facilities consist of the brine production facility and the brine injection facility. Inclined drilling of wells is utilized, which enables the production wells and injection wells to be grouped close together at the surface. This results in minimizing the surface piping and the associated capital cost. 
At the surface, the wells are spaced at 50-foot intervals in two rows. The distance between the rows is 150 feet.

Production Wells. Geothermal brine from each production well is transported as a two-phase fluid in an 8-inch diameter pipe to the main header located between the two rows of the production wells. The header diameter is 16 inches at the farthest point from the plant and increases, in the direction of flow, to 24 inches and finally to 36 inches in diameter near the power plant. Production piping is insulated and supported above ground on steel structures.

Injection Wells. Spent brine from the injection pump discharge is transported to the injection island in a 24-inch-diameter pipe. The header is located in the middle of two rows of wells, and each well is fed by an 8-inch-diameter pipe from the header. Injection piping is insulated and supported above ground on steel structures.

Materials of Construction. Carbon steel has been assumed as the appropriate material for piping and equipment associated with the production and injection of brine.

\section{2 \\ COST ESTIMATE}

The cost estimate consists of two parts. The first part is total capital cost associated with production of brine, the power plant, and injection of brine. The second part is the cost of 
TABLE 4-5

CAPITAL COST ESTIMATE SUMMARY $(1)$

50 MWe (NET) DUAL FLASH ENERGY CONVERSION

SALTON SEA KGRA, NILAND, CALIFORNIA

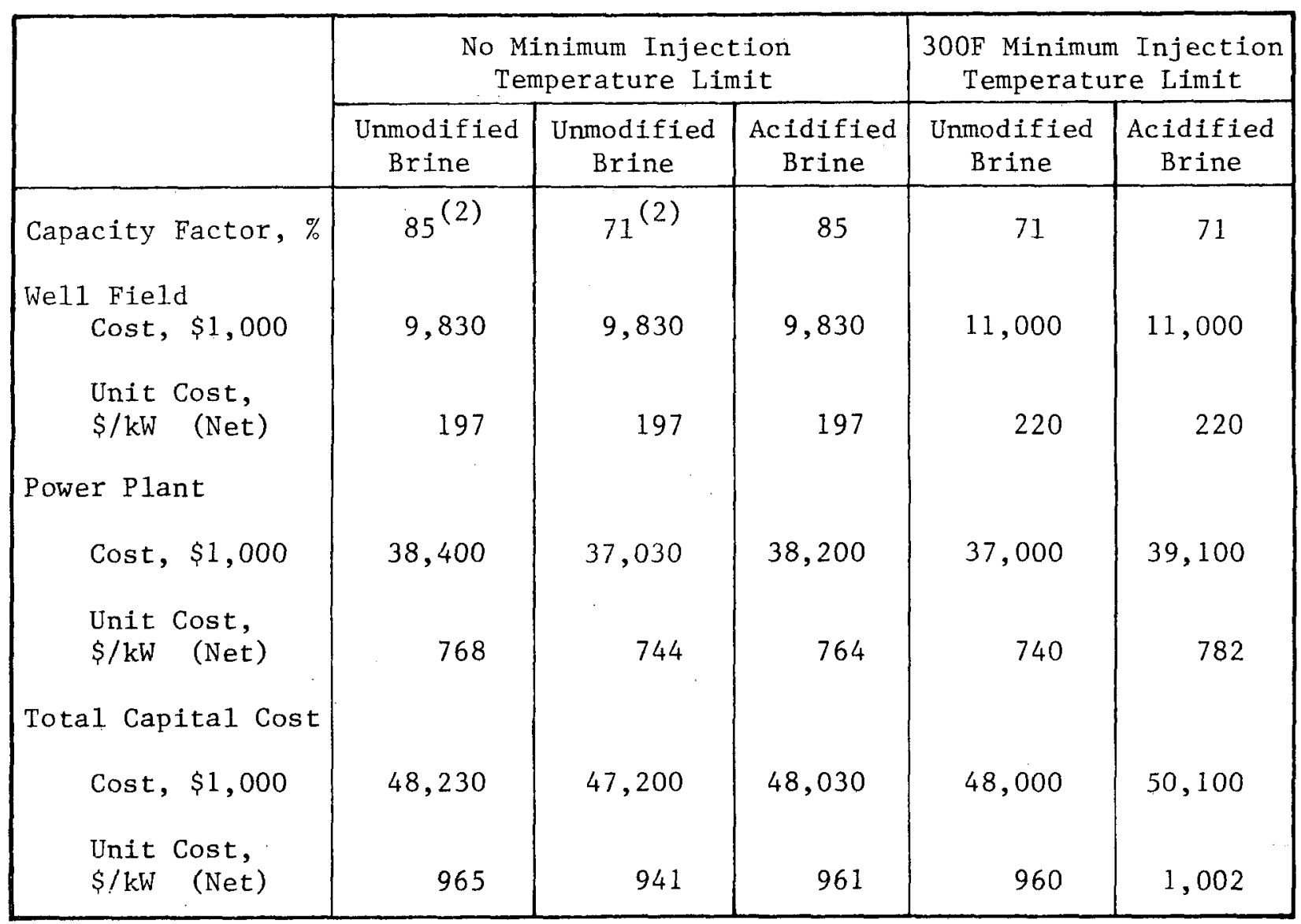

Notes:

(1) Based on first quarter 1982 dollars.

(2) $71 \%$ capacity factor corresponds to two $50 \%$ capacity flash vessel trains (No Redundant F1ash Vesse1 Case).

$85 \%$ capacity factor corresponds to three $50 \%$ capacity flash vessel trains (Redundant Flash Vessel Case). 
producing energy. Table 4-5 shows the summary of the capital costs for the five cases studied. Capital costs of power plants and well fields are reported separately. Appendix A. Cost Estimating Methodology, describes the cost estimating methods.

\subsubsection{Capital Cost of Power Plant}

Power plant capital cost estimates are based on equipment lists, major piping requirements, plot plans, and flow diagrams. Tables 4-6 through 4-10 show the detailed capital costs for the cases studied. Equipment and subcontract costs for the turbine-generator. hydrogen sulfide abatement system, main condenser, and cooling tower have been obtained from the suppliers of these equipment. Even though there is a small difference in required performance of these equipment items, as related to the no minimum injection temperature and $300 \mathrm{~F}$ injection temperature cases, the same equipment, and hence the same cost, have been assumed to be applicable to all cases.

\subsubsection{Capital cost of Well Field}

Well field capital cost estimates are based on the well schedule, major piping requirements, plot plans, flow diagrams, and the cost of wells furnished by the Magma Power Company. Table 4-11 shows the detailed capital cost of the well field for the cases considered. Acidification of the brine in the power plant to reduce scaling does not affect the well field cost, since the 
TABLE $\quad 4-6$

CAPITAL COST ESTIMATE - POWER PLANT

50 MWe (NET) DUAL FLASH ENERGY CONVERSION

SALTON SEA KGRA, NILAND, CALIFORNIA

NO MINIMUM BRINE INJECTION TEMPERATURE, UNMODIFIED BRINE

CAPACITY FACTOR 85\%

\begin{tabular}{|c|c|c|}
\hline & $\begin{array}{l}\text { Labor } \\
\$ 1,000\end{array}$ & $\begin{array}{c}\text { Material } \\
\$ 1,000\end{array}$ \\
\hline $\begin{array}{l}\text { Mechanica1 Equipment } \\
\text { Turbine Generator } \\
\mathrm{H}_{2} \mathrm{~S} \text { Abatement System } \\
\text { Tanks and Vessels } \\
\text { Condenser and Vacuum Equipment } \\
\text { Cooling Tower } \\
\text { Pumps and Drives } \\
\text { Other } \\
\text { Piping and Instrumentation } \\
\text { Electrical } \\
\text { Civil/Structural } \\
\text { Yardwork and Miscellaneous }\end{array}$ & $\begin{array}{r}340 \\
168 \\
58 \\
128 \\
106 \\
56 \\
44 \\
252 \\
315 \\
836 \\
79 \\
\end{array}$ & $\begin{array}{r}6,086 \\
1,107 \\
656 \\
2,074 \\
1,025 \\
1,308 \\
485 \\
1,021 \\
960 \\
851 \\
54 \\
\end{array}$ \\
\hline $\begin{array}{l}\text { Direct Field Cost } \\
\text { Indirect Cost a } 65 \% \text { of Direct Labor } \\
\text { Total Field Cost } \\
\text { Engineering Service a } 14 \%\end{array}$ & $\begin{array}{l}2,382 \\
1,548 \\
3,930 \\
2,740 \\
\end{array}$ & $\begin{array}{l}\frac{-}{15,627} \\
15,627 \\
- \\
\end{array}$ \\
\hline $\begin{array}{l}\text { Total Field Cost Plus Engineering Cost } \\
\text { Contingency @ 20\% } \\
\text { Total Construction Cost } \\
\text { First Quarter } 1978 \text { Dollars } \\
\text { Escalation }\end{array}$ & $\begin{array}{r}6,670 \\
3,570 \\
10,240 \\
2,660 \\
\end{array}$ & $\begin{array}{r}15,627 \\
893 \\
\\
16,520 \\
3,140 \\
\end{array}$ \\
\hline $\begin{array}{l}\text { Construction Cost Plus Escalation } \\
\text { Owner's Cost @ } 8 \% \\
\text { Capital Cost Before AFDC } \\
\text { AFDC }\end{array}$ & $\begin{array}{r}12,900 \\
2,100 \\
15,000 \\
1,400 \\
\end{array}$ & $\begin{array}{r}19,660 \\
540 \\
20,200 \\
1,800 \\
\end{array}$ \\
\hline $\begin{array}{l}\text { Total Capital Cost } \\
\text { First Quarter } 1982 \text { Dollars }\end{array}$ & 16,400 & 22,000 \\
\hline TOTAL & \multicolumn{2}{|c|}{38,400} \\
\hline
\end{tabular}


TABLE 4-7

CAPITAL COST ESTIMATE - POWER PLANT

50 MWe (NET) DUAL FLASH ENERGY CONVERSION

SALTON SEA KGRA, NILAND, CALIFORNIA

NO MINIMUM BRINE INJECTION TEMPERATURE, UNMODIFIED BRINE

CAPACITY FACTOR 71\%

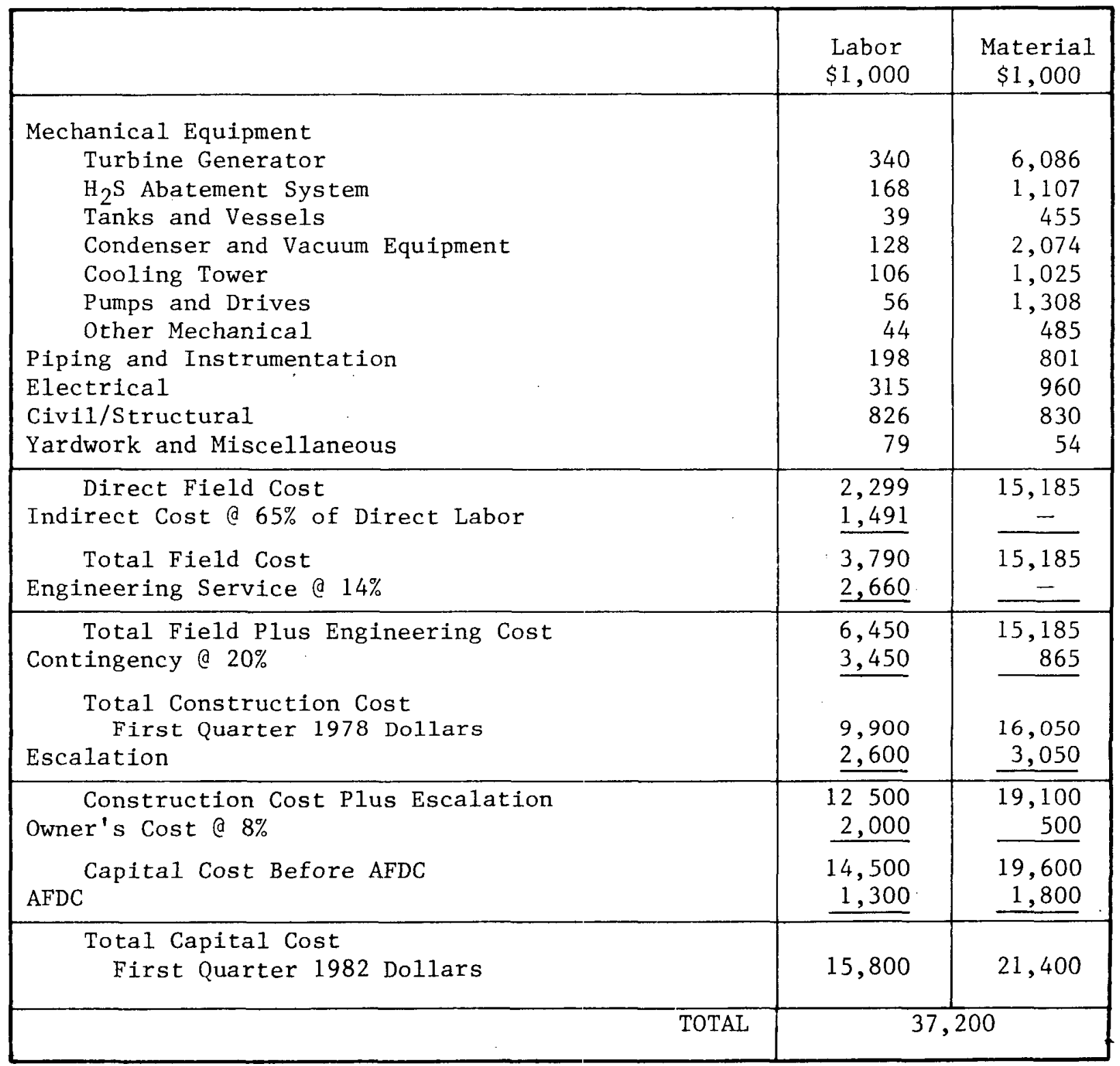


TABLE $4-8$

CAPITAL COST ESTIMATE - POWER PLANT

50 MWe (NET DUAL FLASH ENERGY CONVERSION

SALTON SEA KGRA, NILAND, CALIFORNIA

NO MINIMUM BRINE INJECTION TEMPERATURE, ACIDIFIED BRINE

CAPACITY FACTOR 85\%

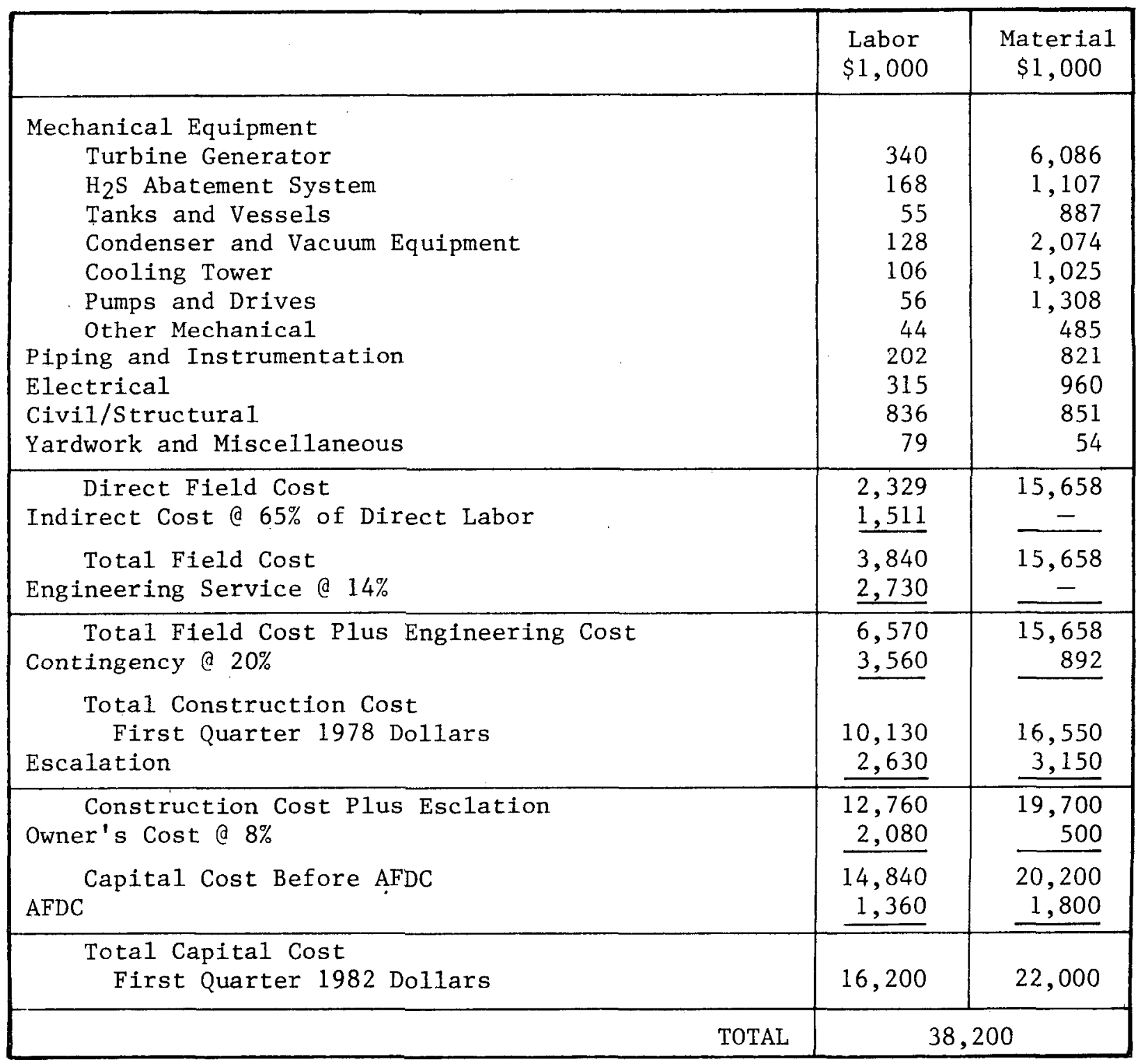


TABLE $4-9$

CAPITAL COST ESTIMATE - POWER PLANT

50 MWe (NET) DUAL FLASH ENERGY CONVERSION

SALTON SEA KGRA, NILAND, CALIFORNIA

NO MINIMUM BRINE INJECTION TEMPERATURE, UNMODIFIED BRINE

CAPACITY FACTOR 71\%

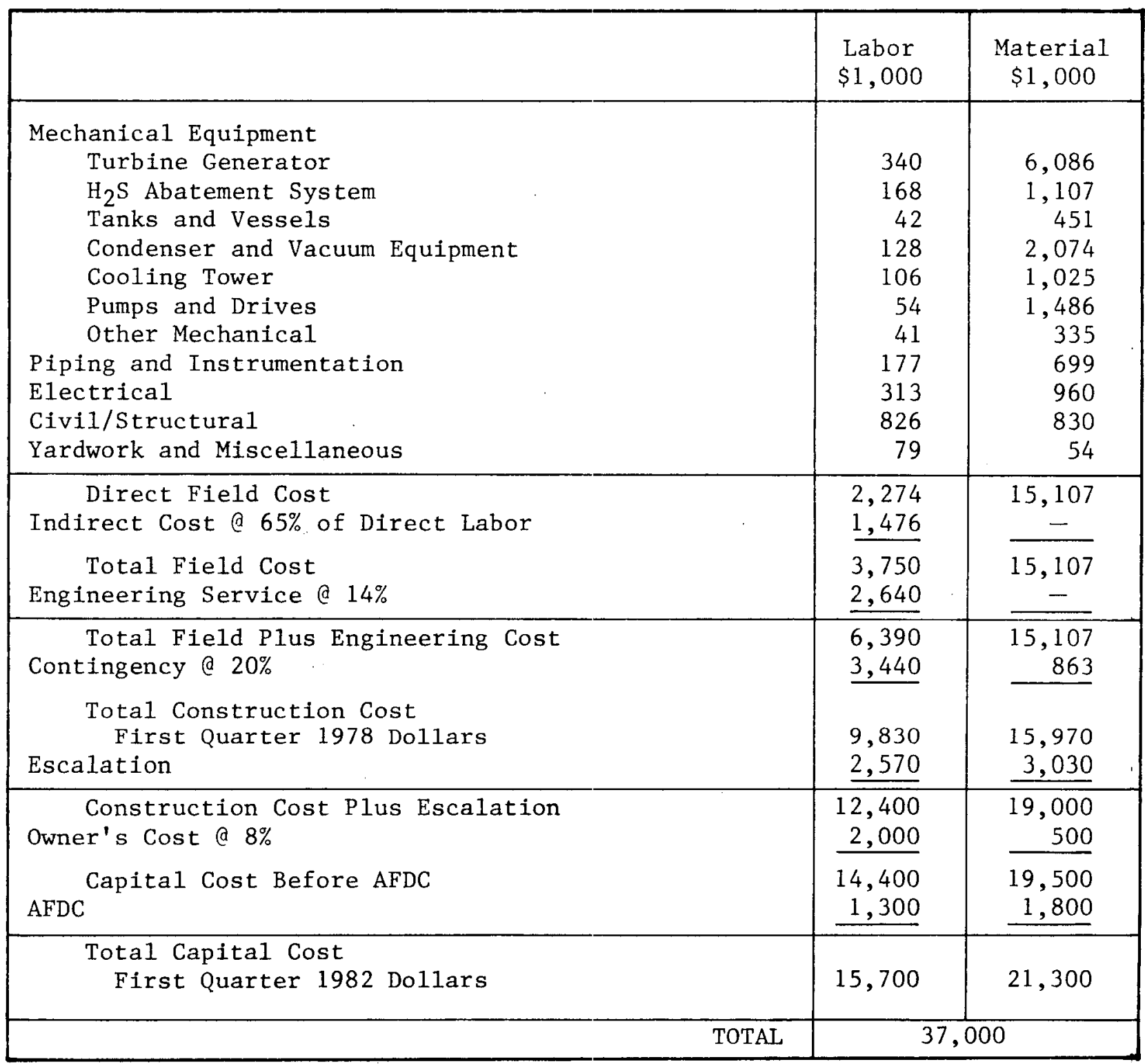


TABLE $\quad 4-10$

CAPITAL COST ESTIMATE - POWER PLANT

50 MWe (NET) DUAL FLASH ENERGY CONVERSION

SALTON SEA KGRA, NILAND, CALIFORNIA

NO MINIMUM BRINE INJECTION TEMPERATURE, ACIDIFIED BRINE

CAPACITY FACTOR 71\%

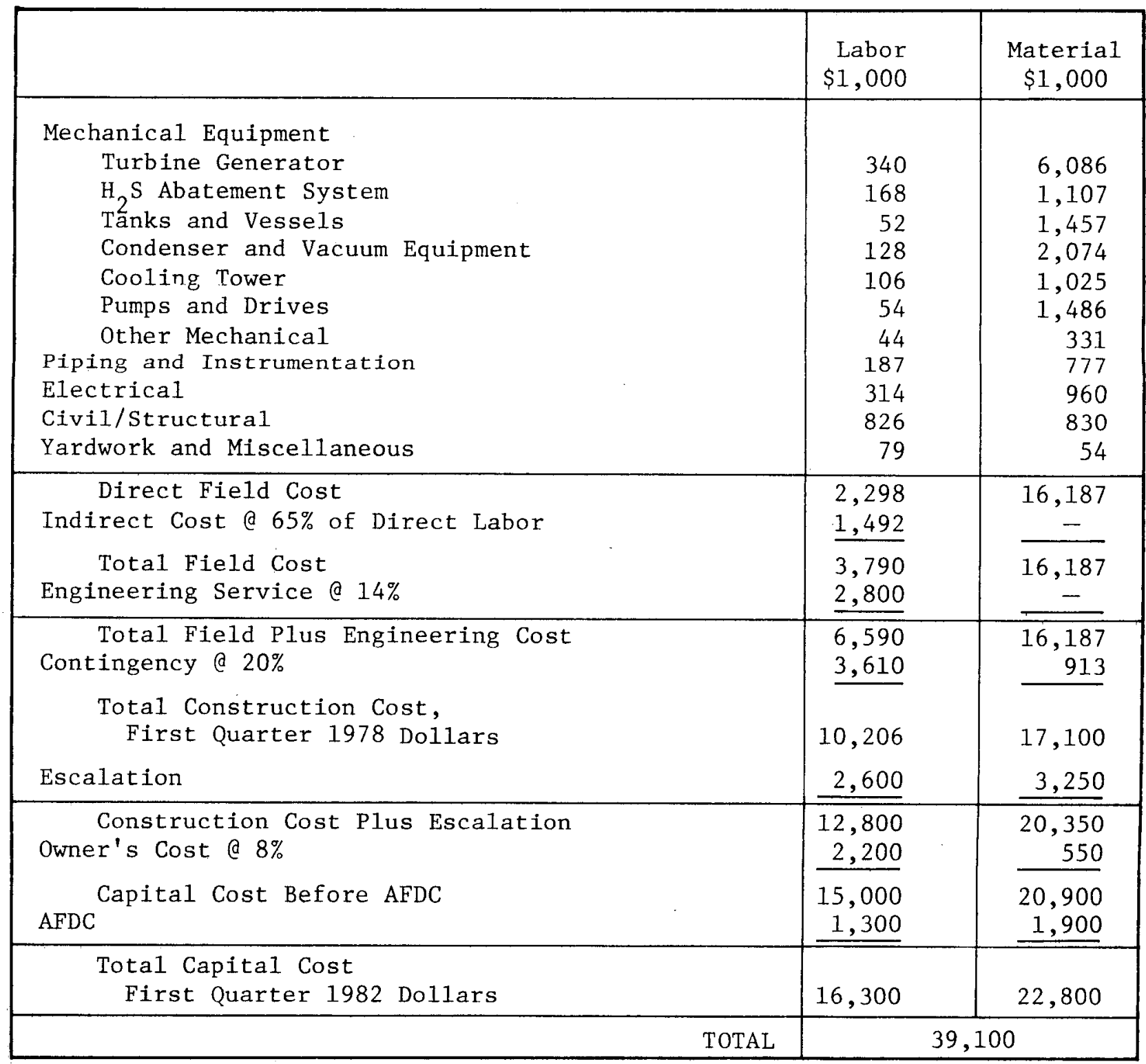


TABLE $4-11$

CAPITAL COST ESTIMATE, WELL FIELD ${ }^{(1)}$

$(\$ 1,000)$

50 MWe (NET) DUAL FLASH ENERGY CONVERSION SALTON SEA KGRA, NILAND, CALIFORNIA

\begin{tabular}{|c|c|c|c|c|c|c|c|c|}
\hline & \multicolumn{4}{|c|}{ No Minimum Injection Temperature Limit } & \multicolumn{4}{|c|}{ 300F Minimum Injection Temperature Limit } \\
\hline & \multicolumn{2}{|c|}{ Unmodified Brine } & \multicolumn{2}{|c|}{ Acidified Brine } & \multicolumn{2}{|c|}{ Unmodified Brine } & \multicolumn{2}{|c|}{ Acidified Brine } \\
\hline & Labor & Material & Labor & Material & Labor & Material & Labor & Material \\
\hline \multicolumn{9}{|l|}{ Brine Supply Lines } \\
\hline Materials and Subcontracts & 8 & 147 & 8 & 147 & 9 & 160 & 9 & 160 \\
\hline Installation & 74 & - & 74 & - & 82 & - & 82 & - \\
\hline \multicolumn{9}{|l|}{ Brine Injection Lines } \\
\hline Materials and Subcontracts & 14 & 731 & 14 & 731 & 14 & 735 & 14 & 735 \\
\hline Installation & 202 & - & 202 & - & 213 & - & 213 & - \\
\hline Total Field Cost of Lines & 298 & 878 & 298 & 878 & 318 & 895 & 318 & 895 \\
\hline Engineering \& $14 \%$ & 164 & - & 164 & - & 167 & - & 167 & - \\
\hline Total Field and Engineering & 462 & 878 & 462 & 878 & 485 & 895 & 485 & 895 \\
\hline Contingency a $20 \%$ & 218 & 52 & 218 & 52 & 220 & 55 & 220 & 55 \\
\hline $\begin{array}{l}\text { Total Construction Cost of Lines, First } \\
\text { Quarter } 1978 \text { Dollars }\end{array}$ & 680 & 930 & 680 & 930 & 705 & 950 & 705 & 950 \\
\hline Geotherma1 We11s (subcontracts) & 2,170 & 4,030 & 2,170 & 4,030 & 2,395 & 4,350 & 2,395 & 4,350 \\
\hline $\begin{array}{l}\text { Total Construction Cost of Well Field, First } \\
\text { Quarter } 1978 \text { Dollars }\end{array}$ & 2,850 & 4,960 & 2,850 & 4,960 & 3,100 & 5,300 & 3,100 & 5,300 \\
\hline Escalation & 750 & 940 & 750 & 940 & 900 & 1,200 & 900 & 1,200 \\
\hline Construction and Escalation Costs & 3,600 & 5,900 & 3,600 & 5,900 & 4,000 & 6,500 & 4,000 & 6,500 \\
\hline AFDC & 160 & 270 & 160 & 270 & 200 & 300 & 200 & 300 \\
\hline Total Capital Cost, & 3,760 & 6,170 & 3,760 & 6,170 & 4,200 & 6,800 & 4,200 & 6,800 \\
\hline First Quarter 1982 Dollars $(1)$ & \multirow{2}{*}{\multicolumn{2}{|c|}{$\begin{array}{c}9,830 \\
85 \% \approx 71 \%\end{array}$}} & \multirow{2}{*}{\multicolumn{2}{|c|}{$\begin{array}{l}9,830 \\
85 \%\end{array}$}} & \multicolumn{2}{|c|}{11,000} & \multicolumn{2}{|c|}{11,000} \\
\hline Capacity Factor & & & & & & & & $\%$ \\
\hline
\end{tabular}

Note:

(1) Installed cost of well field at start of operation. 
brine will be neutralized prior to injection and the same materials of construction are used for all cases.

\subsubsection{Capacity Factors}

The capacity factor for each case has been calculated on the assumption that the best long-term capacity factor that can be achieved in a relatively scale-free geothermal power plant is 85 percent. For all cases, where scale buildup in power plant and brine piping is such that it is necessary to shutdown or partially load the generator for removing the scale, the capacity factor of 85 percent will be reduced to allow scale removal. However, the 85 percent capacity factor is not expected to be achieved by the first demonstration plant until it has been in operation for perhaps five years: it is more appropriate for later plants, where the design is based on experience gained from the demonstration plant. The rationales for the values of the capacity factors used in the five cases included in this study are described in the following paragraphs.

No Minimum Injection Temperature, Unmodified Brine, Redundant Flash Vessels. The capacity factor for this case is 85 percent. Three separate 50 percent capacity flash vessels and associated piping are furnished so that the scale removal of any one train can be accomplished while furnishing 100 percent flashed steam to the turbine-generator. This arrangement does not require any scheduled downtime of the entire power plant for scale removal. It is assumed that scale buildup in the injection line is very 
sma11, and it can be cleaned at any time during unscheduled downtime or downtime that is scheduled for other purposes.

No Minimum Injection Temperature, Unmodified Brine, Without Redundant Flash Vessels. If only two 50 percent capacity flash vessel trains are furnished and downtime of two weeks every 1000 hours is assumed for cleaning, a plant capacity factor of 75 percent results. Assuming two more weeks per year of unscheduled downtime (i.e.. 4 percent:), the plant capacity factor will be 71 percent.

No Minimum Injection Temperature, Acidified Brine. The capacity factor for this case is 85 percent, since the brine is acidified in the power plant and regular scheduled downtime for cleanup is not required. Here again, the injection line cleanup can be arranged during downtime scheduled for other purposes. Scaling in the power plant will be limited to the three 50 percent capacity first-stage flash vessels and their associated piping. Any two of these will always furnish 100 percent primary steam to the turbine.

300F Minimum Injection Temperature, Unmodified Brine.

The capacity factor for this case is 71 percent. It is assumed that the plant will have a scheduled downtime of two weeks for cleaning primarily the injection line every, 1000 hours, in addition to some scale cleanup in the power plant. This results in the plant capacity factor of 75 percent. Assuming two more weeks of unscheduled downtime (i.e., 4 percent) per year, the 
capacity factor is 71 percent. Providing three trains of flash vessels, as in the no minimum injection temperature case, does not improve the capacity factor for this case because of the amount of regular cleaning required for the injection line.

$300 \mathrm{~F}$ Minimum Injection Temperature, Acidified Brine.

The capacity factor for this case is 71 percent. Due to acidification, the scaling in the power plant is minimized and no regular shutdown for cleaning is required. However, the injection line, which carries the neutralized brine, does scale up and a regular scheduled downtime of two weeks every 1000 hours has been assumed for cleaning this line. This results in a capacity factor of 75 percent. Assuming 4 percent additional unscheduled downtime results in a capacity factor of 71 percent.

\subsubsection{Energy Production Costs}

Table 4-12 shows the energy production costs in mills/kwh for the five cases studied. Cost estimating methods used for calculating the energy cost are explained in Appendix A. The cost of cleaning the scale is based on extrapolation of the quantity of chemicals and manhours expended for the GLEF. General cost for operation and maintenance of the power plant is based on information available for existing geothermal plants at The Geysers, but manpower has been increased to account for differences, such as brine handling. Brine treatment cost covers the cost of acid and caustic and is based on the information furnished by the Lawrence Livermore Laboratory. Cost for solids 
TABLE $\quad 4-12$

ENERGY PRODUCTION COSTS ESTIMATES

(1)

50 MWe (NET) DUAL FLASH ENERGY CONVERSION
SALTON SEA KGRA, NILAND, CALIFORNIA

\begin{tabular}{|c|c|c|c|c|c|}
\hline & \multicolumn{3}{|c|}{$\begin{array}{l}\text { No Minimum Injection } \\
\text { Temperature Limit }\end{array}$} & \multicolumn{2}{|c|}{$\begin{array}{c}\text { 300F Minimum Injection } \\
\text { Temperature Limit }\end{array}$} \\
\hline & $\begin{array}{c}\text { Unmodified } \\
\text { Brine }\end{array}$ & $\begin{array}{l}\text { Unmodified } \\
\text { Brine }\end{array}$ & $\begin{array}{c}\text { Acidified } \\
\text { Brine }\end{array}$ & $\begin{array}{l}\text { Unmodified } \\
\text { Brine }\end{array}$ & $\begin{array}{l}\text { Acidified } \\
\text { Brine }\end{array}$ \\
\hline Capacity Factor (\%) & $85^{(2)}$ & $71(2)$ & 85 & 71 & 71 \\
\hline $\begin{array}{l}\text { Power Plant } \\
\text { Depreciation } \\
\text { Return on Investment } \\
\text { Income Taxes and Ad } \\
\text { Valorem Taxes } \\
\text { Plant Insurance } \\
\text { Operation and Maintenance } \\
\text { General } \\
\text { Scale Removal } \\
\text { Brine Treatment } \\
\text { Solid Hauling } \\
\text { Administration and General } \\
\text { Total Power Plant } \\
\text { Cost }\end{array}$ & $\begin{array}{r}3.4 \\
8.4 \\
\\
5.6 \\
0.1 \\
2.2 \\
1.5^{2} \\
0.3 \\
-\quad \\
0.4 \\
0.6 \\
20.3\end{array}$ & $\begin{array}{l}4.0 \\
9.7 \\
\\
6.5 \\
0.1 \\
2.6 \\
1.8^{2} \\
0.3 \\
-\quad 0.5 \\
0.6 \\
23.5\end{array}$ & $\begin{array}{r}3.4 \\
8.3 \\
\\
5.5 \\
0.1 \\
3.1 \\
1.4^{3} \\
- \\
1.3 \\
0.4 \\
\quad 0.8 \\
21.2\end{array}$ & 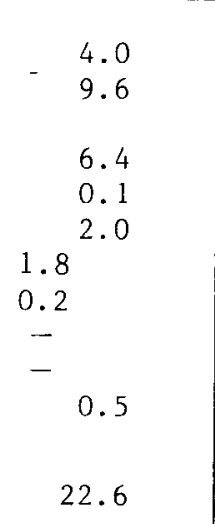 & $\begin{array}{r}4.2 \\
10.2 \\
\\
6.8 \\
0.1 \\
3.2 \\
1.8^{3.2} \\
- \\
1.4 \\
-0.8 \\
25.3\end{array}$ \\
\hline $\begin{array}{l}\text { We1l Field } \\
\text { Depreciation } \\
\text { Return on Investment } \\
\text { Income Taxes } \\
\text { Ad Valorem Taxes } \\
\text { Operation and Maintenance } \\
\text { General } \\
\text { Scale Removal ( } 3) \\
\text { Production Well Replacement } \\
\text { Injection Well Replacement } \\
\text { Administration and General } \\
\text { Royalties } \\
\text { Total Well Field Cost }\end{array}$ & $\begin{array}{r}0.9 \\
4.5 \\
3.8 \\
1.7 \\
2.8 \\
2.8 \\
0.0 \\
1.3 \\
0.3 \\
0.3 \\
1.7 \\
17.3\end{array}$ & $\begin{array}{r}1.1 \\
5.3 \\
4.5 \\
2.1 \\
3.3 \\
3.3 \\
0.0 \\
1.5 \\
0.4 \\
0.3 \\
2.1 \\
20.6\end{array}$ & $\begin{array}{r}0.9 \\
4.5 \\
3.8 \\
1.7 \\
2.8 \\
2.8 \\
0.0 \\
1.3 \\
0.3 \\
0.3 \\
1.7 \\
17.3\end{array}$ & $\begin{array}{c}1.2 \\
5.9 \\
5.0 \\
2.4 \\
4.5 \\
4.3^{4} \\
0.2 \\
1.6 \\
0.5 \\
0.5 \\
2.4 \\
24\end{array}$ & $\begin{array}{l}1.2 \\
5.9 \\
5.0 \\
2.4 \\
4.5 \\
4.3 \\
0.2 \\
1.6 \\
0.5 \\
0.5 \\
2.4 \\
24\end{array}$ \\
\hline Total Energy Cost & 37.6 & 44.1 & 38.5 & 46.6 & 49.3 \\
\hline
\end{tabular}

Notes:

(1) Based on first quarter 1932 dollars.

(2) $71 \%$ capacity factor corresponds to two $50 \%$ capacity flash vessel trains (no redundant flash vessel case). $85 \%$ capacity factor corresponds to three $50 \%$ capacity flash vessel trains (redundant flash vessel case).

(3) Scale removal costs associated with well field energy costs for no minimum injection temperature cases are negligible, i.e., less than $0.1 \mathrm{mill} / \mathrm{kWh}$. 
hauling applies to cases with a brine settling pond when the sludge, after being processed in a centrifuge, is assumed to be hauled away. Minor scale removal costs associated with the acidified brine cases and the chemical costs associated with the stretford process and the cooling tower were found to be negligible and are not included in the power plant operating and maintenance costs. 
Section 5

BINARY PROCESS

The binary process is characterized by the use of a secondary working fluid, such as a light hydrocarbon. Since the working fluid is heated by the geothermal fluid, additional equipment is required as compared to the flashed steam process. The cost of this additional equipment must be justified by a higher process efficiency and a lower overall cost of produced power.

\subsection{CONCEPTUAL DESIGN}

Four different designs were considered, covering a range of technical assumptions. A four-stage flash binary process (no acid): assumes unmodified brine, heavy scaling, moderate corrosion and no minimum injection temperature. A four-stage flash binary process (with acid): assumes brine modified by acid addition, no scaling, high corrosion, and no minimum injection temperature.

A two-stage flash binary process: assumes unmodified brine, heavy scaling, moderate corrosion, and a minimum injection temperature of 300F. A liquid/liquid heat exchange binary process: assumes brine modified by acid addition, no scaling, high corrosion, and no minimum injection temperature. Although many more variations are possible, these" process designs cover a wide range. They should provide a reasonable basis for 
comparison with the flashed steam process, considering the existing information available for the salton sea area.

\subsubsection{Tradeoff Analyses}

The choice of hydrocarbon for use as a working fluid and hydrocarbon cycle conditions were based on computerized cycle studies. Steam flash conditions and brine reject temperatures were obtained by matching the hydrocarbon cycle. Changes to the hydrocarbon cycle were made when dictated by steam flash requirements or to reduce brine consumption. The number of flash stages was set at four as the result of an earlier study made for the Niland location. Two stages were used for the 300F injection case as a matter of engineering judgment. Although further improvements in cycle efficiency and economics could probably be effected, the improvements would probably not be significant in terms of the purposes of this study.

\subsubsection{Energy Conversion Processes}

In the power plants using the closed loop binary process the hot geothermal brine transfers heat to a working fluid in indirect contact heat exchangers such as shell-and-tube heat exchangers. The working fluid, a hydrocarbon, has a boiling point at the operating pressure which is lower than the brine temperature and it leaves the heat exchanger as a saturated or slightly superheated vapor. The vapor is expanded in a turbine to convert thermal energy to mechanical energy and the expanded 
vapor is condensed and recycled to the heat exchangers, thus closing the loop. The cooled brine is reinjected into the reservoir.

Three processes are described, which differ in the way in which heat is transferred to the working fluid. The hot brine entering the plant is free flowing and contains about 10 percent steam by weight.

In the four-stage flash binary process, the brine is separated from the steam and then subjected to three more flashes, thus generating steam at four different temperatures. The working fluid is heated and vaporized countercurrent by the steam in four stages. The two-stage flash binary process is similar to the four-stage process, but only two flashes are employed and the brine is reinjected at a higher temperature (300F).

In the liquid/liquid binary process, brine is separated from the steam and heat is transferred from the liquid brine to the liquid working fluid in a shell-and-tube heat exchanger. The working fluid is then vaporized in a separate heat exchanger by heat transferred from the steam.

\subsubsection{Four-Stage Flash Binary Process}

A flow sheet with heat and material balance for this process is shown in Figure 5-1 (Drawing 7748-D-3202) and the enthalpy cycle is presented in Figure 5-2. 
Hot brine enters the flash vessel $\mathrm{V}-1$ at $374 \mathrm{~F}$ and 150 psia. The steam is separated from the brine and scrubbed with condensate. The brine, which may or may not be treated to adjust acidity, flows to the flash vessel $V-2$ where the pressure is reduced to $95 \mathrm{psia}$. The steam generated in $\mathrm{V}-2$ is separated from the brine and scrubbed with condensate. The flashing process is repeated two more times in vessels $V-3$ and $V-4$ until the pressure is reduced to $17 \mathrm{psia}$. At this point the brine temperature is $233 \mathrm{~F}$. The brine is neutralized, if required, and settled to remove solids; and finally pumped to the injection wells.

Hydrocarbon recycled from the hydrocarbon condenser is heated by the steam from the flash vessels in four stages, E-6, E-4, E-2 and E-1. Condensate from each of these hydrocarbon heaters is used to heat hydrocarbon in intermediate heaters, E-7, E-5 and E-3, allowing the condensate temperature in each heater to drop to the temperature of the steam from the next flash. In this manner both condensate and steam are passed countercurrent to the hydrocarbon for optimum heat transfer. The condensates are joined successively with condensed steam from the following stage and thus all condensates pass through the heat exchanger $(E-7)$ to be cooled to $133 \mathrm{~F}$ so that maximum heat recovery can be achieved. The cold condensate is used as makeup water in the cooling tower $\mathrm{CT}-1$. 


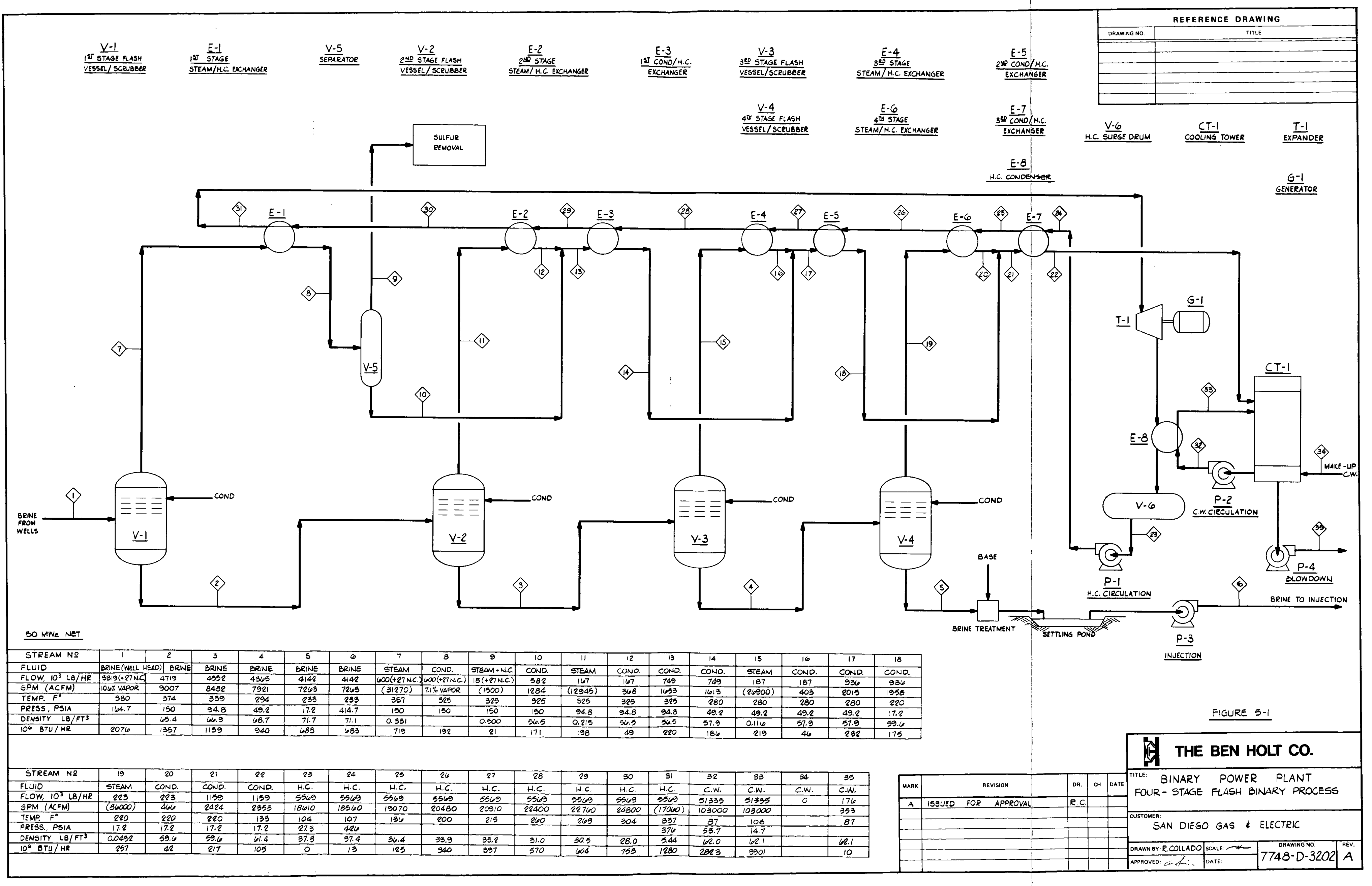




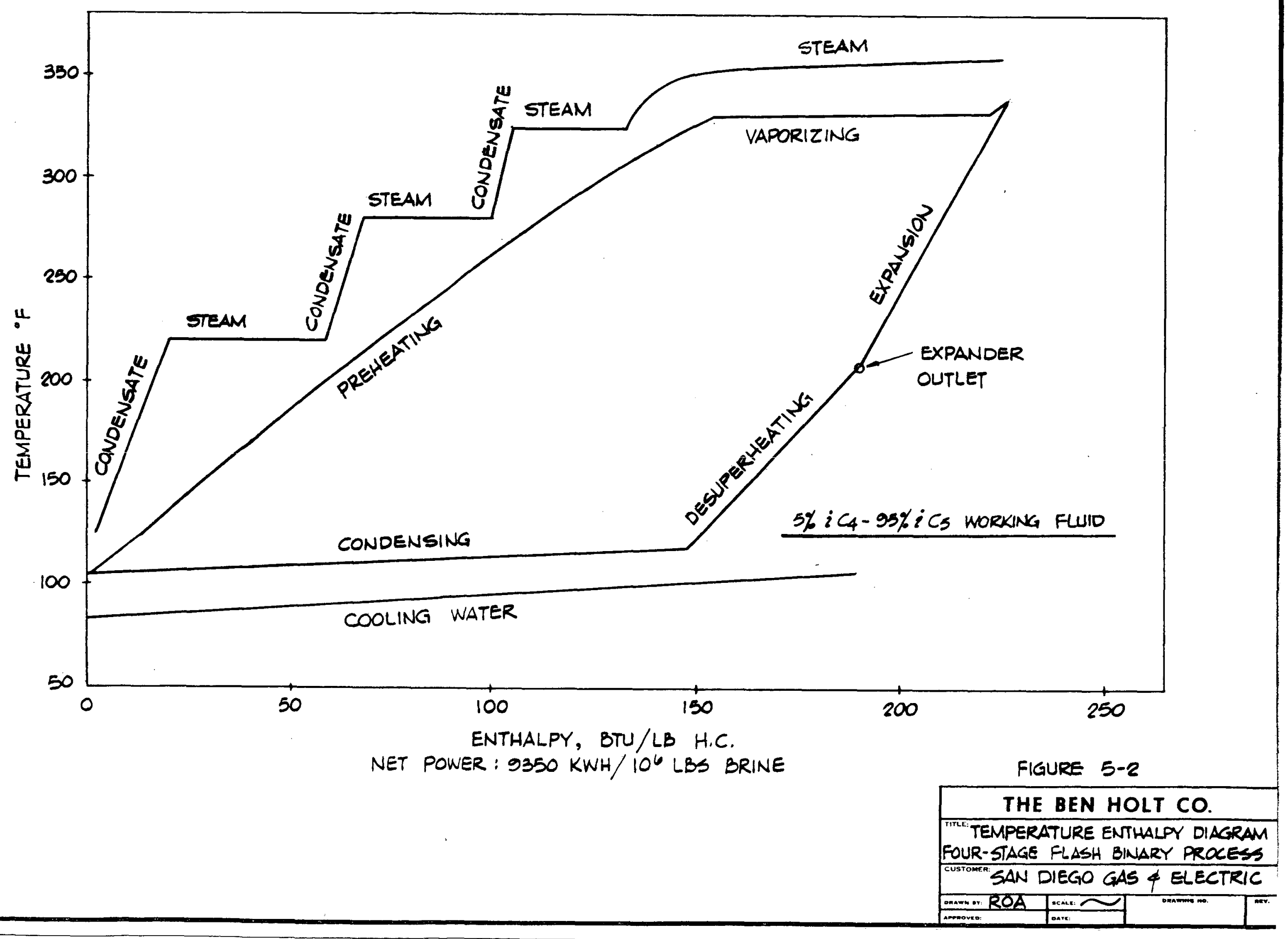




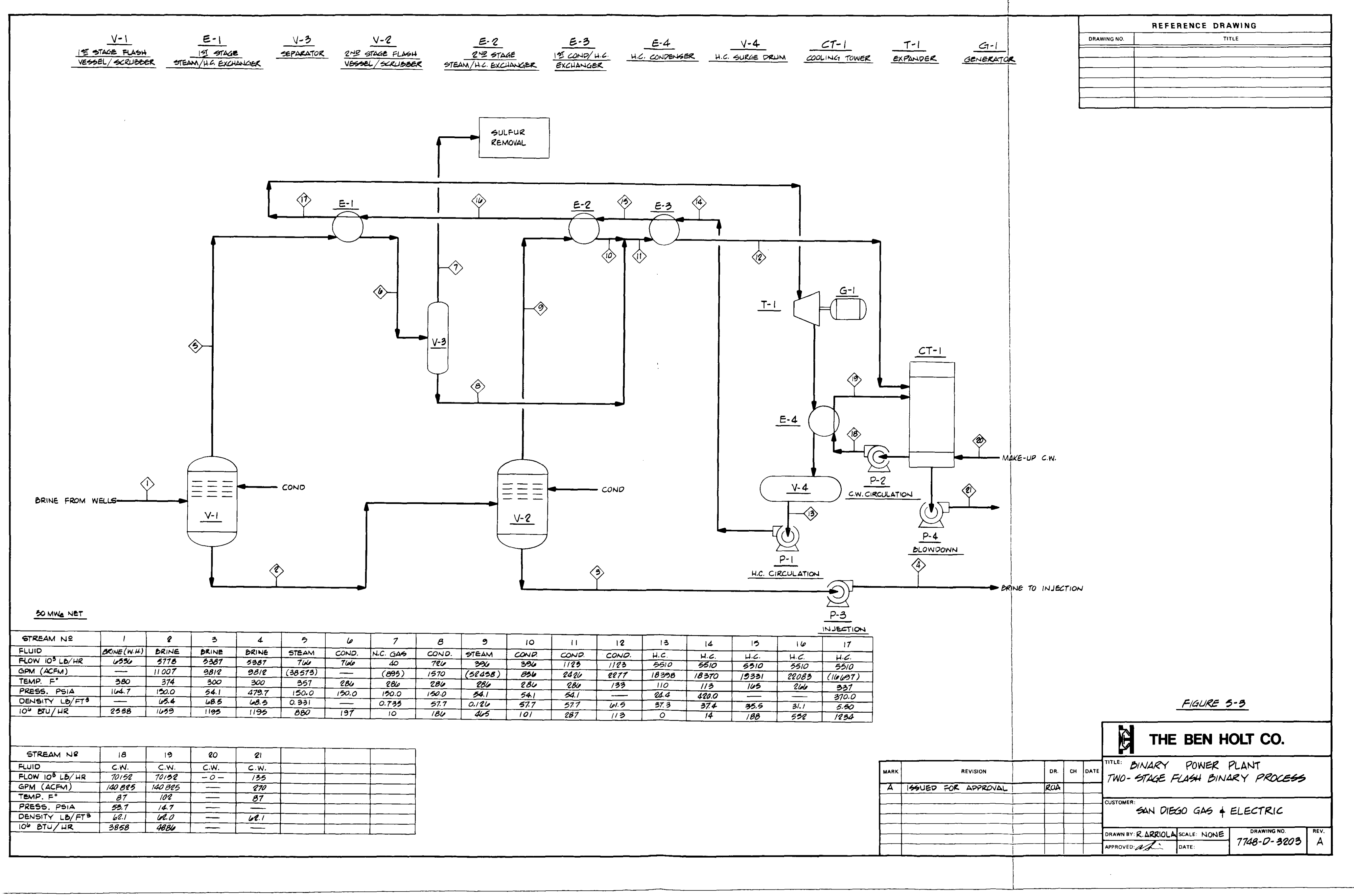




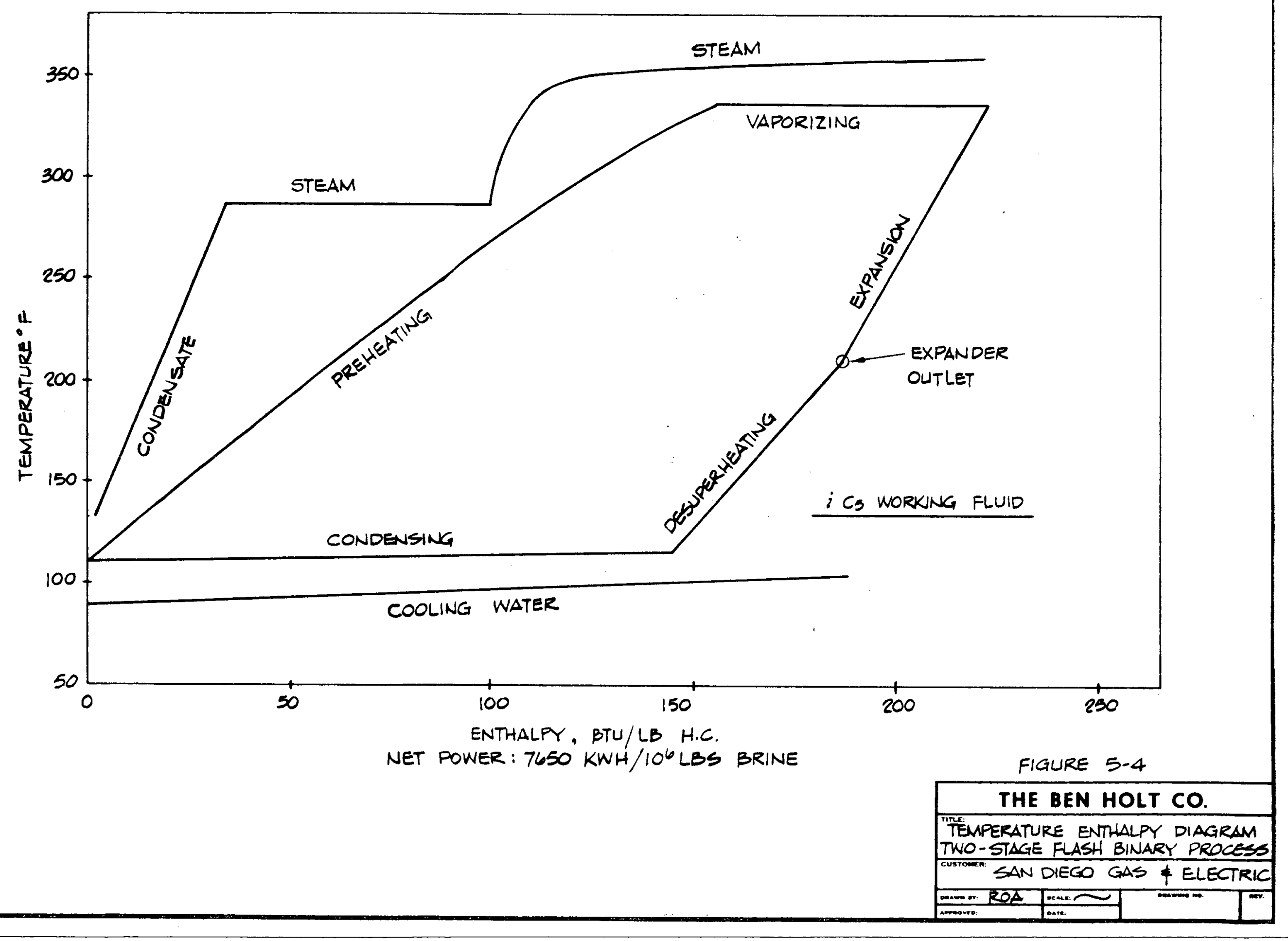


The scrubbed steam from the first stage $V-1$ enters heat exchanger E-1 saturated at $357 \mathrm{~F}$. As the steam condenses giving off its latent heat to the hydrocarbon, the condensing temperature decreases due to the presence of noncondensibles. These are vented at $325 \mathrm{~F}$ which is the temperature of the steam from the next flash. Thus, there is no intermediate heater between the first and second flash and the condensate from E-1 is joined directly with the condensate from E-2.

The hydrocarbon is heated from $107 \mathrm{~F}$ to $337 \mathrm{~F}$ in heat exchangers E-7 through E-1. At this point the hydrocarbon is a slightly superheated vapor at $376 \mathrm{psia}$. The vapor is expanded in the turbine T-1 driving the generator, and is then cooled and condensed in the condenser E-8. The condensed hydrocarbon is stored in the accumulator $v-6$ for recycling to the heating process.

The cooling water for the condensers is circulated over the cooling tower. Under normal conditions the condensate is more than sufficient for makeup and the blowdown is about $350 \mathrm{gal} / \mathrm{min}$.

\subsubsection{Two-Stage Flash Binary Process}

The two-stage flash binary process is shown in Figure 5-3 (Drawing 7748-D-3203) and the enthalpy cycle is presented in Figure 5-4. 
This process is designed for a brine injection temperature of $300 \mathrm{~F}$. Hot brine enters the flash vessel $\mathrm{V}-1$ at $374 \mathrm{~F}$ and 150 psia. The steam is separated from the brine and scrubbed with condensate. The brine flows to the flash vessel $\mathrm{V}-2$ where the pressure is reduced to 54 psia. At this point the temperature is $300 \mathrm{~F}$ and the brine from $\mathrm{V}-2$ is pumped to the injection wells. The steam generated in $\mathrm{V}-2$ is scrubbed with condensate.

Hydrocarbon recycled from the hydrocarbon condenser is preheated with hot condensate and is further heated and vaporized by steam from the two flash vessels. The hydrocarbon leaving the heat exchangers is slightly superheated at $337 \mathrm{~F}$. The vapor is expanded in the turbine T-l. driving the generator and is then cooled and condensed in condensers E-4. The condensed hydrocarbon is stored in accumulators $V-4$ for recycling to the heating process.

The cooling water for the condensers is circulated over the cooling tower CT-1. Under normal conditions the condensate is more than sufficient for makeup.

\subsubsection{Liquid/Liquid Binary Process}

A flow sheet with heat and material balance for this process is shown in Figure 5-5 (Drawing 7748-D-3201) and the enthalpy cycle is presented in Figure 5-6. 
Hot brine enters flash vessel $\mathrm{V}-1$ at $374 \mathrm{~F}$ and $150 \mathrm{psia.} \mathrm{The}$ steam is separated from the brine and scrubbed with condensate. The brine is acidified after leaving $V-1$ and is then sent to heat exchangers $E-2$ where it is cooled to about $160 \mathrm{~F}$ giving off heat to the hydrocarbon, which is heated from $138 \mathrm{~F}$ to $320 \mathrm{~F}$. The brine is neutralized and settled for removal of solids and is finally pumped to the injection wells.

The heated hydrocarbon, which is at or near its boiling point of $320 \mathrm{~F}$ at about $338 \mathrm{psia}$, is vaporized and superheated to $337 \mathrm{~F}$ in heat exchangers E-1. The scrubbed steam from $V-1$ is used to vaporize the hydrocarbon. It enters E-1 saturated at $357 \mathrm{~F}$. As the steam condenses giving off its latent heat to the hydrocarbon, the condensing temperature decreases due to the presence of noncondensibles. These are vented at $340 \mathrm{~F}$ and the condensate is further cooled in heat exchangers E-3 to preheat the hydrocarbon which is recycled to the heating process from surge drums $\mathrm{V}-2$. The cold condensate is used as makeup water in the cooling tower $\mathrm{CT}-1$.

The hydrocarbon vapor is expanded in turbine T-l driving the generator, and is then cooled and condensed in condensers E- 4 . It is stored in accumulators $\mathrm{V}-2$ for recycling to the heating process.

The cooling water for the condensers is circulated over the cooling tower. Makeup water and condensate are pumped to 


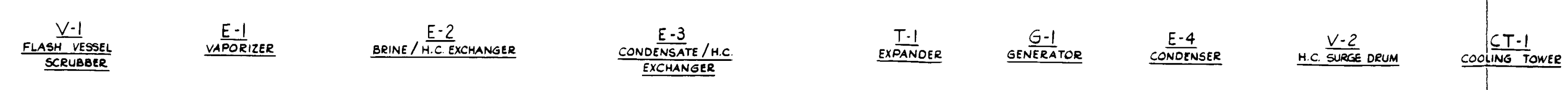

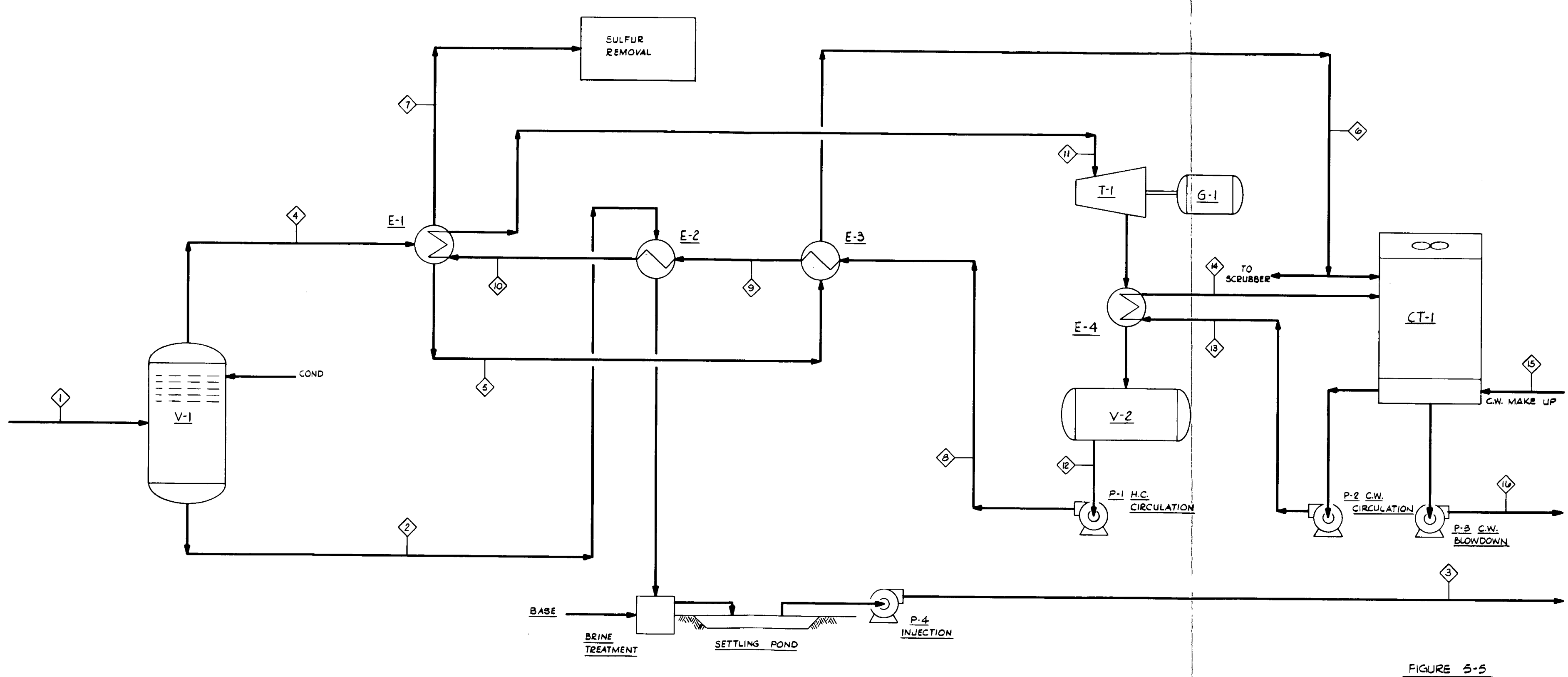




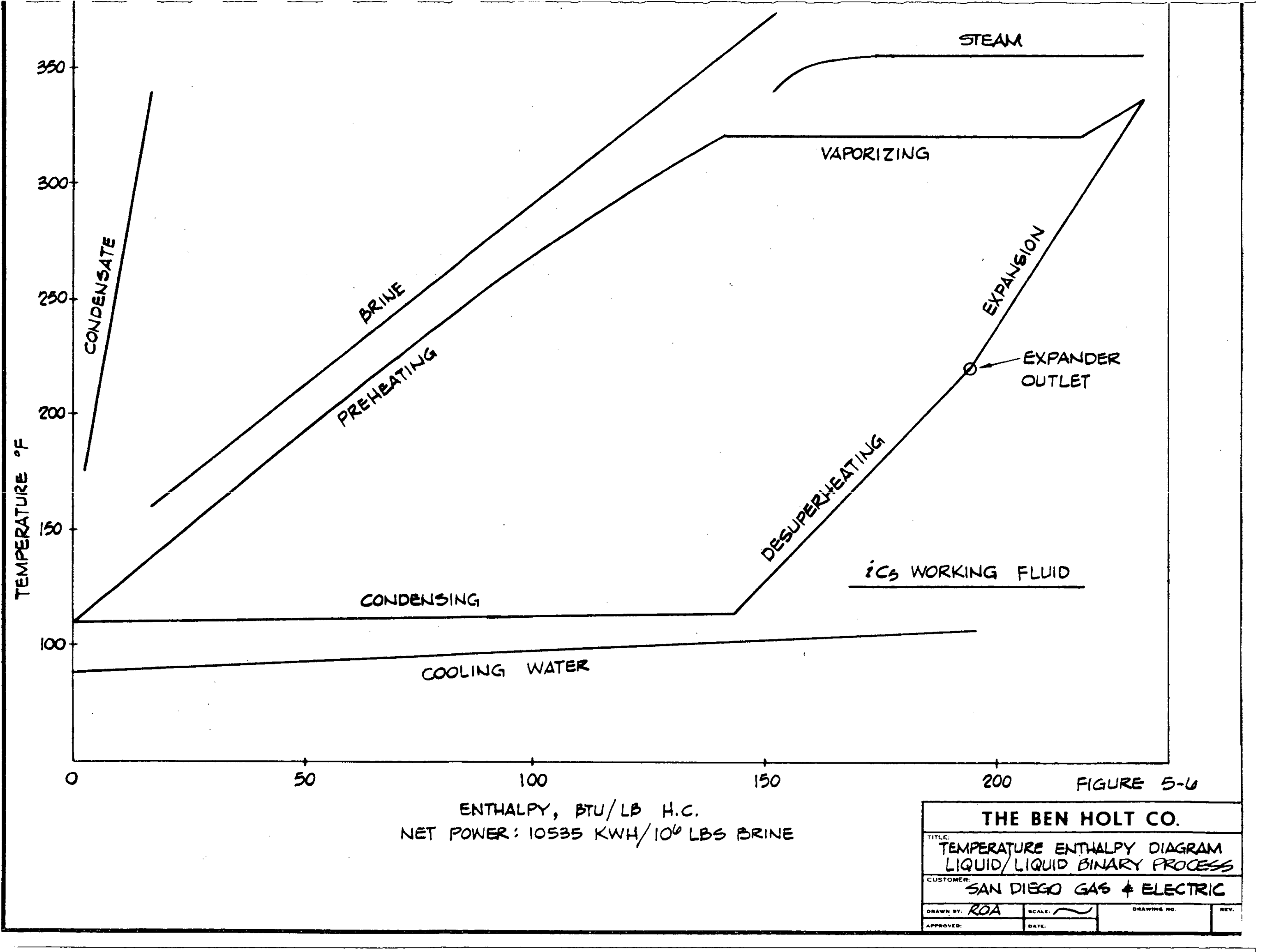


the cooling tower to maintain a concentration factor of 3 in the blowdown.

\subsubsection{Plant Performance and Auxiliary Power Requirements}

Table 5-1 is a summary of plant performance data and auxiliary power requirements. The liquid/liquid binary process is the most efficient, with a specific net output of $10.54 \mathrm{Wh} / \mathrm{lb}$. The four-stage flash process has a specific net output of $9.35 \mathrm{Wh} / \mathrm{lb}$, followed by the two-stage flash at $7.65 \mathrm{Wh} / \mathrm{lb}$. Total auxiliary power requirements increase from $8,600 \mathrm{~kW}$ for the liquid/liquid process, to $8,650 \mathrm{~kW}$ for the four-stage process, to $10,070 \mathrm{~kW}$ for the two-stage process. All of the above is for end-of-run conditions, with a downhole temperature of $482 \mathrm{~F}$.

TABLE 5-1

PLANT PERFORMANCE

\begin{tabular}{|c|r|r|r|}
\hline & \multicolumn{3}{|c|}{ BINARY PROCESS } \\
\cline { 2 - 4 } $\begin{array}{c}\text { Niquid/Liquid } \\
\text { Exchanger }\end{array}$ & $\begin{array}{c}4-\text { Stage } \\
\text { Flash }\end{array}$ & $\begin{array}{c}\text { 2-Stage } \\
\text { Flash }\end{array}$ \\
\cline { 2 - 5 } Auxiliary Power, kW & 50,000 & 50,000 & 50,000 \\
Cooling Water Pump & 2,370 & 1,940 & 2,660 \\
Injection Pump & 1,580 & 1,580 & 2,280 \\
H.C. Circulation Pump & 3,460 & 4,040 & 3,960 \\
Cooling Tower Fan & 1,040 & 940 & 1,020 \\
Miscellaneous Loads & 150 & 150 & 150 \\
Total Aux. Power, kW & 8,600 & 8,650 & 10,070 \\
Power Generated, Gross, kW & 58,600 & 58,650 & 60,070 \\
Brine Flow Rate 10 1bs/hr & 4.746 & 5.346 & 6.536 \\
Downhole Temperature, F & 482 & 482 & 482 \\
Specific Net Output, Wh/1b Brine & 10.54 & 9.35 & 7.65 \\
Net Brine Rate lb Brine/kWh & 94.9 & 107.0 & 130.7 \\
Turbine Generator Efficiency, & & & \\
Expander & 84.6 & 84.6 & 84.6 \\
Electrical & 99.0 & 99.0 & 99.0 \\
\hline
\end{tabular}




\subsubsection{Power Plant Facilities}

A plot plan for the four-stage flashed steam binary process is shown in Figure 5-7 (Drawing 7748-D-3204). Plot plans for the other binary processes differ so little from that for the fourstage process that only one plot plan is presented.

Tables 5-2, 5-3 and 5-4 are equipment lists for the binary processes. The same equipment list is used for both the acid and nonacid versions of the four-stage process, since differences are limited to materials of construction and corrosion allowances.

\subsubsection{Well Field Facilities}

The well field facilities are essentially the same as those described for the flashed steam process in Section 4 except for number of wells. The number of wells for the binary processes is given in Tables 5-9 and 5-10, Capital cost of well Fields.

\subsection{COST ESTIMATES}

Cost estimating factors and general methods are the same as used for the flashed steam process of section 4 .

\subsubsection{Capital Cost of Power Plants}

The capital cost estimate for the four-stage flash binary power plant (with acid) is summarized in Table 5-5, the four-stage flash binary (no acid) estimate in Table 5-6, the two-stage flash binary estimate in Table 5-7, and the liquid/liquid heat 
TABLE 5-2

MAJOR EQUIPMENT

FOUR-STAGE FLASH BINARY PROCESS

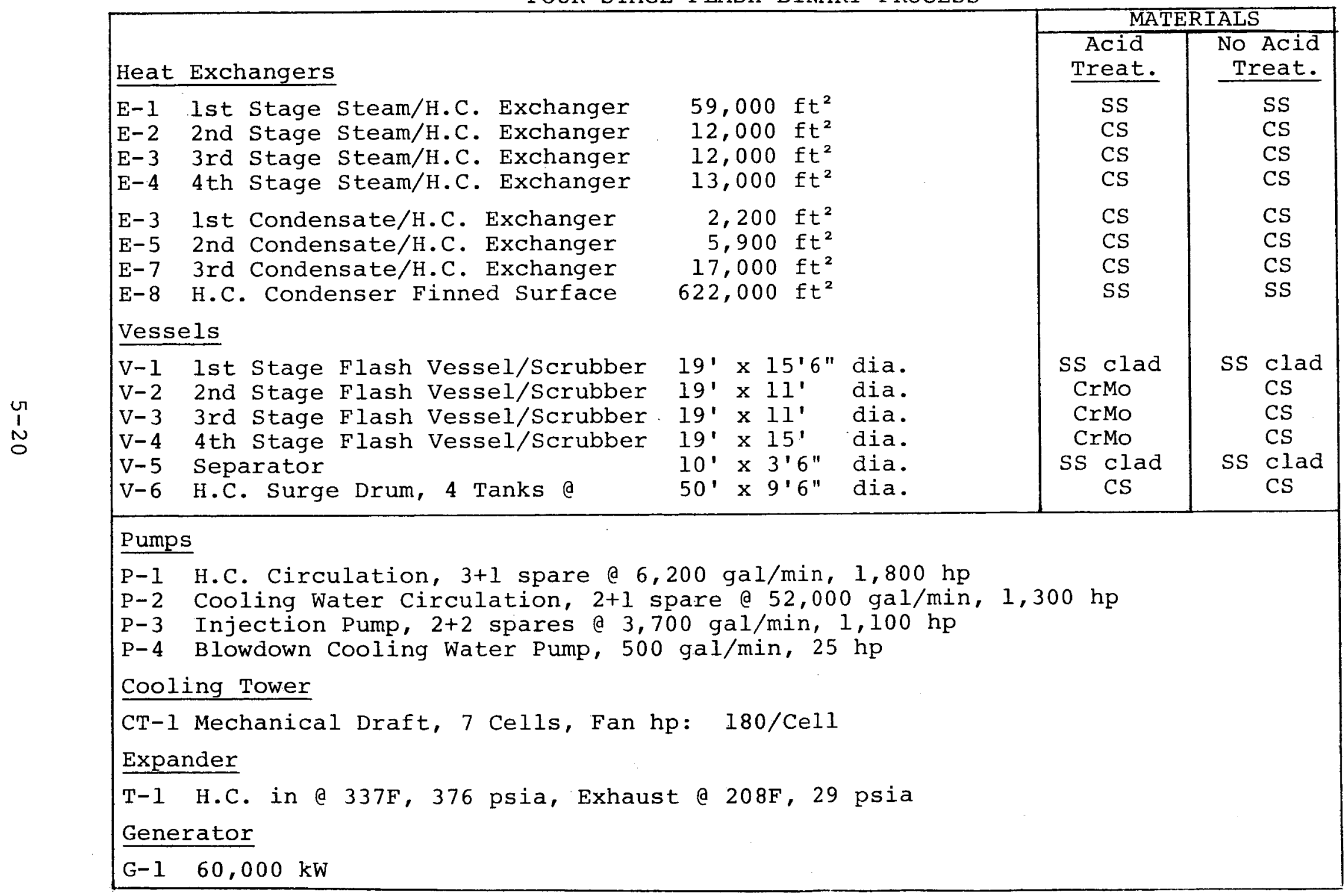




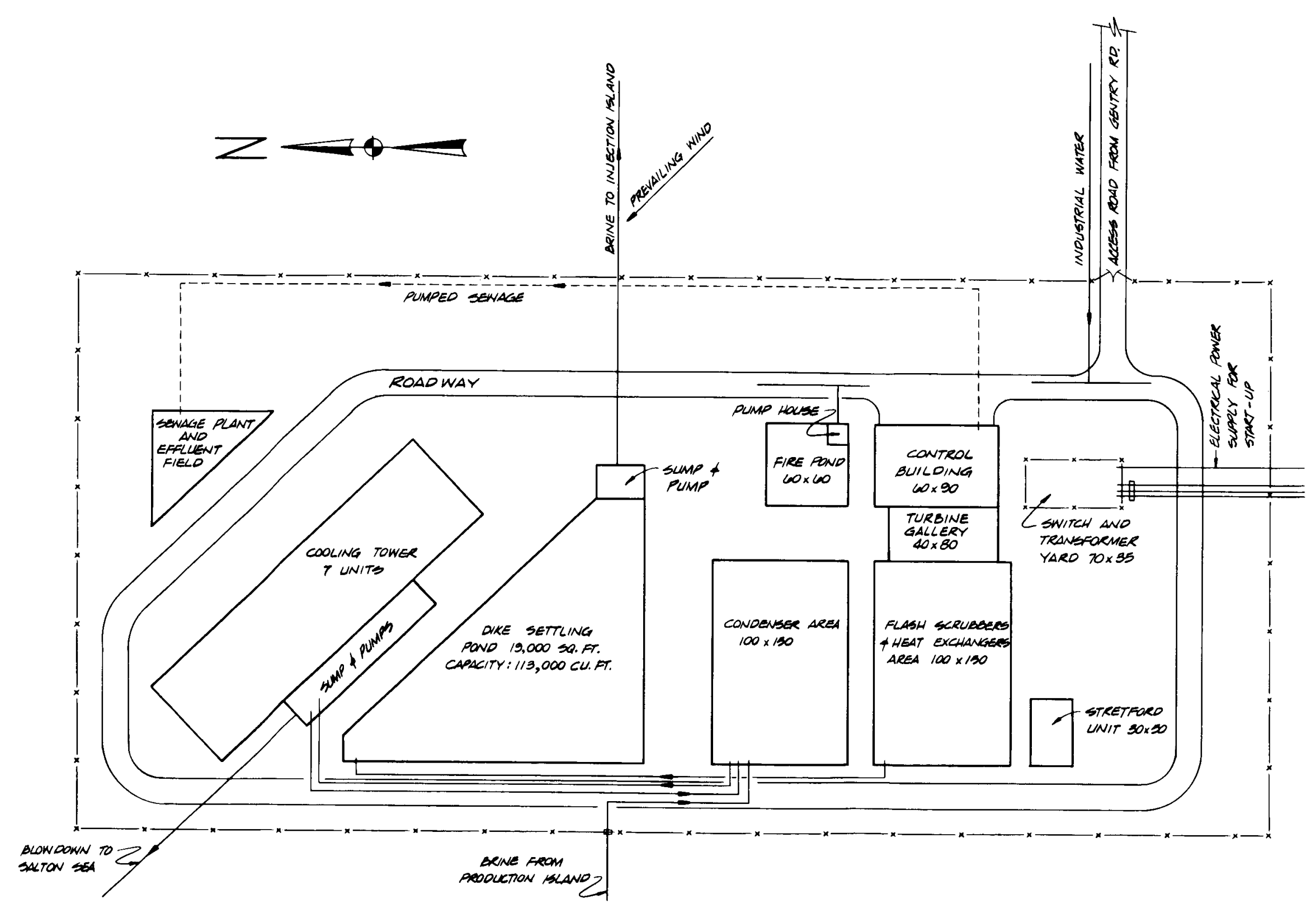

FIGURE 5-7

THE BEN HOLT CO. I TIUE:BNAEY PONER PLANT WITH FLASHED OH. OH OATE STEMINORENG FLUID HEAT EXCHANGER 


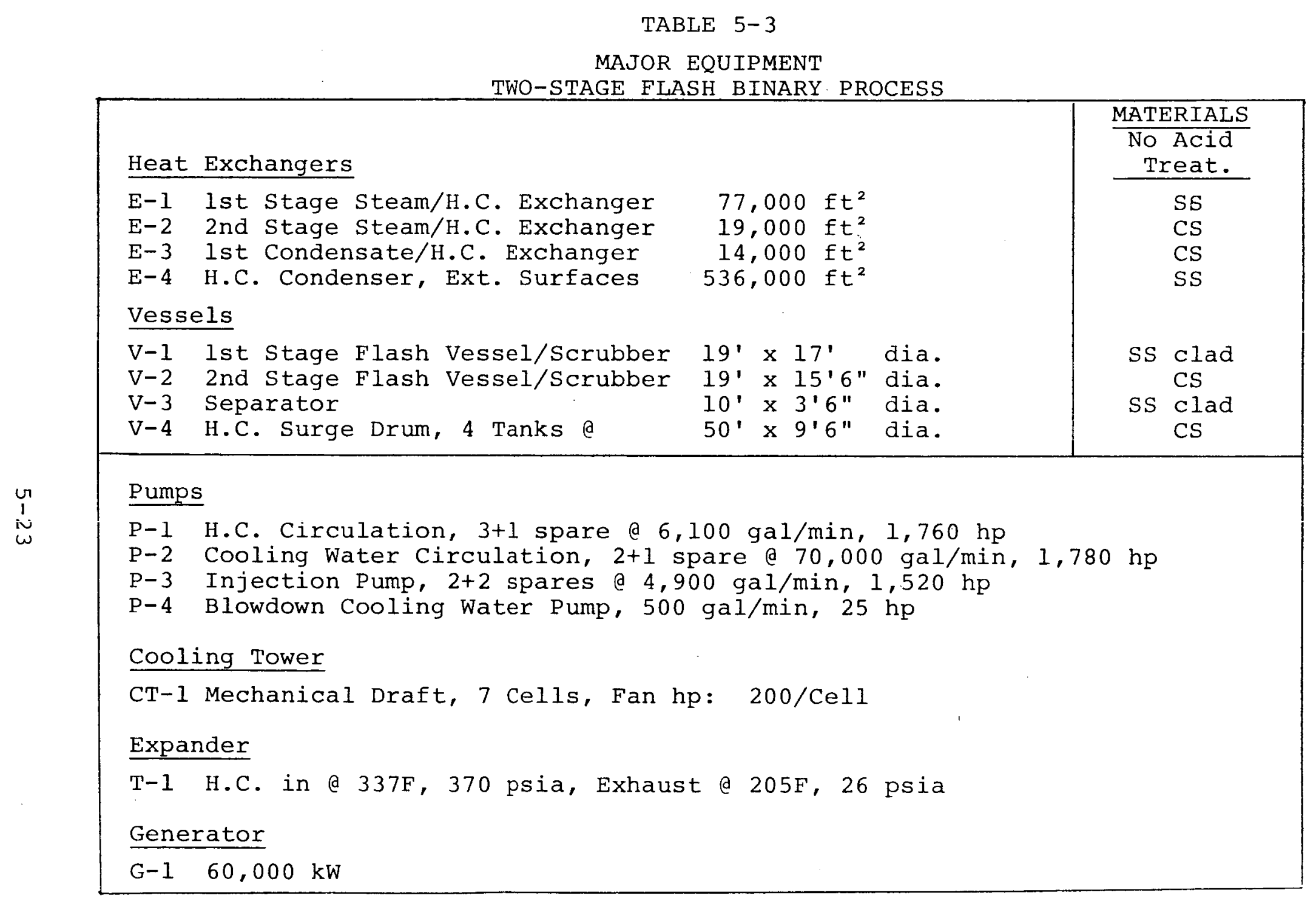


TABLE $\quad 5-4$

MAJOR EQUIPMENT

LIQUID/LIQUID BINARY PROCESS

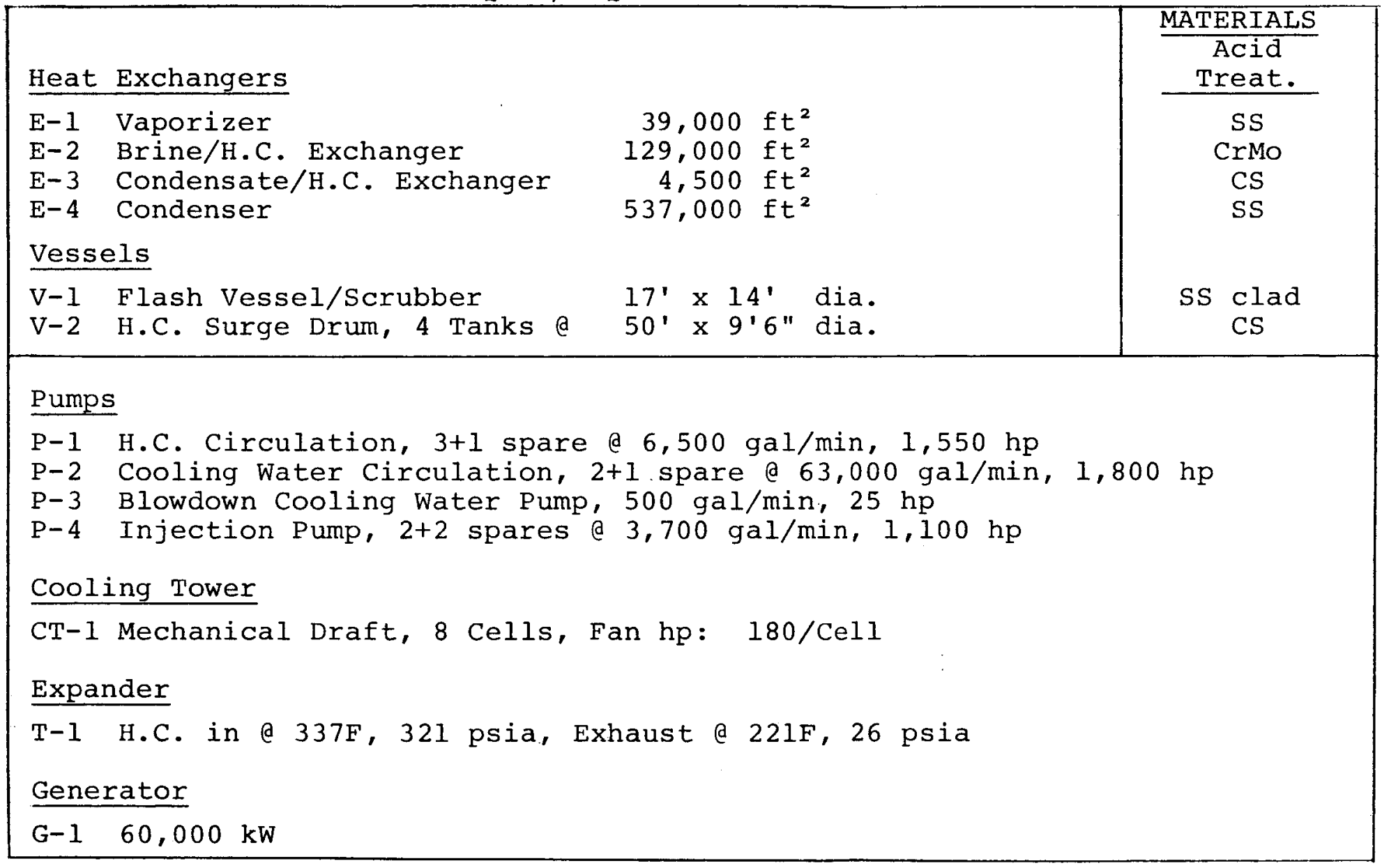


TABLE 5-5

CAPITAL COST ESTIMATE, POWER PLANT

50 MWe (NET) 4 S'TAGE FLASH BINARY

SALTON SEA KGRA, NILAND, CALIFORNIA

NO MINIMUM BRINE INJECTION TEMPERATURE, ACIDIFIED BRINE CAPACITY FACTOR 85\%

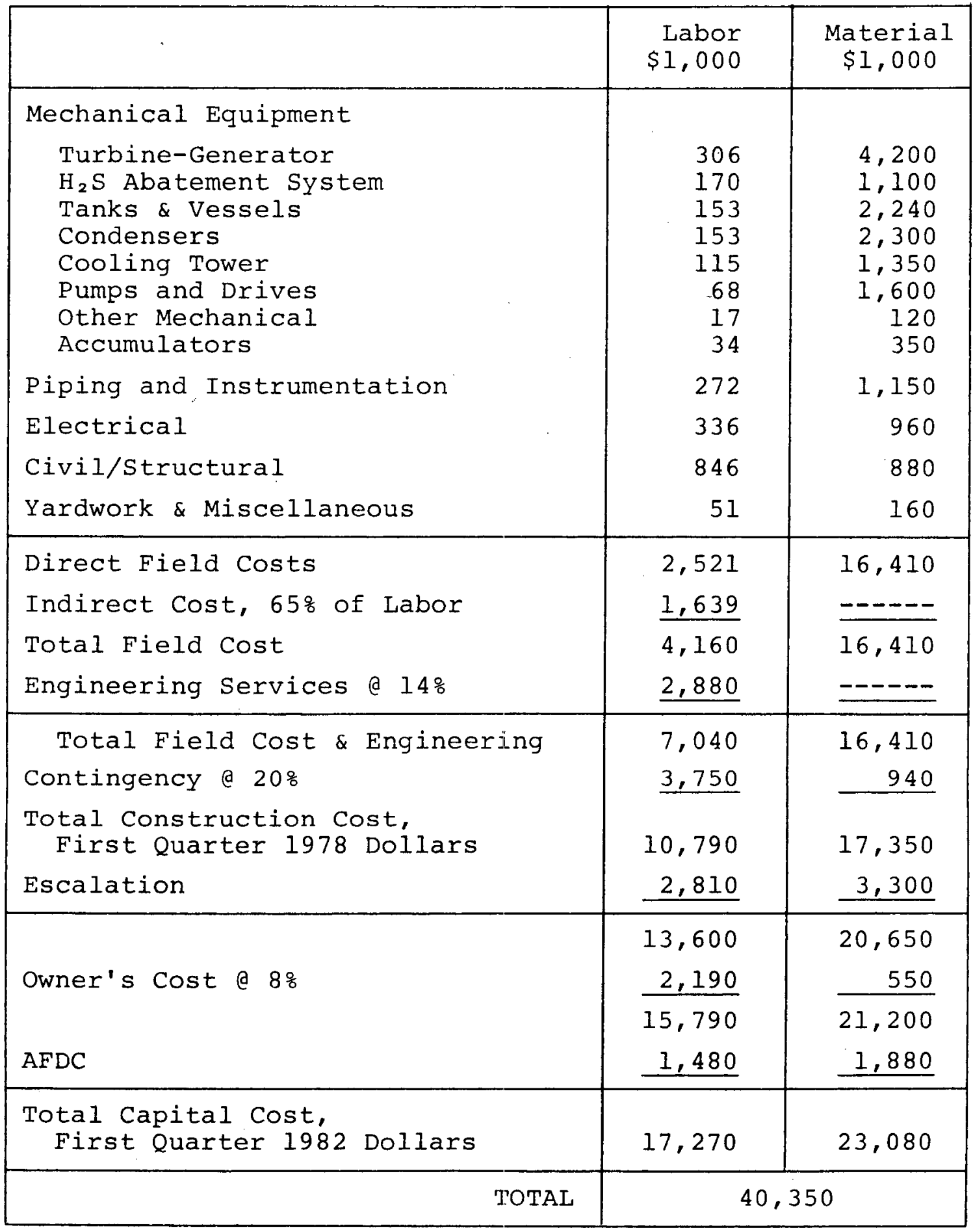


TABLE 5-6

CAPITAL COST ESTIMATE, POWER PLANT 50 MWe (NET) 4 STAGE FLASH BINARY SALTON SEA KGRA, NILAND, CALIFORNIA

NO MINIMUM BRINE INJECTION TEMPERATURE, UNMODIFIED BRINE CAPACITY FACTOR 71\%

\begin{tabular}{|c|c|c|}
\hline & $\begin{array}{l}\text { Labor } \\
\$ 1,000\end{array}$ & $\begin{array}{l}\text { Material } \\
\$ 1,000\end{array}$ \\
\hline Mechanical Equipment & & \\
\hline $\begin{array}{l}\text { Turbine-Generator } \\
\mathrm{H}_{2} \text { S Abatement System } \\
\text { Tanks \& Vessels } \\
\text { Condensers } \\
\text { Cooling Tower } \\
\text { Pumps and Drives } \\
\text { Other Mechanical } \\
\text { Accumulators }\end{array}$ & $\begin{array}{r}306 \\
170 \\
170 \\
153 \\
115 \\
68 \\
17 \\
34\end{array}$ & $\begin{array}{l}4,200 \\
1,100 \\
2,000 \\
2,300 \\
1,350 \\
1,600 \\
120 \\
280\end{array}$ \\
\hline Piping and Instrumentation & 255 & 1,050 \\
\hline Electrical & 336 & 960 \\
\hline Civil/structural & 846 & 880 \\
\hline Yardwork \& Miscellaneous & 51 & 160 \\
\hline Direct Field Costs & 2,521 & 16,000 \\
\hline Indirect Cost, $65 \%$ of Labor & $\underline{1,639}$ & ------ \\
\hline Total Field Cost & 4,160 & 16,000 \\
\hline Engineering Services d $14 \%$ & $\underline{2,820}$ & ----- \\
\hline Total Field Cost \& Engineering & 6,980 & 16,000 \\
\hline Contingency @ $20 \%$ & 3,680 & 920 \\
\hline $\begin{array}{l}\text { Total Construction Cost, } \\
\text { First Quarter } 1978 \text { Dollars }\end{array}$ & 10,660 & 16,920 \\
\hline Escalation & 2,770 & 3,210 \\
\hline & 13,430 & 20,130 \\
\hline Owner's Cost @ $8 \%$ & 2,150 & 540 \\
\hline & 15,580 & 20,670 \\
\hline AFDC & 1,460 & 1,830 \\
\hline $\begin{array}{l}\text { Total Capital Cost, } \\
\text { First Quarter } 1982 \text { Dollars }\end{array}$ & 17,040 & 22,500 \\
\hline TOTAL & \multicolumn{2}{|c|}{39,540} \\
\hline
\end{tabular}


TABLE 5-7

CAPITAL COST ESTIMATE, POWER PLANT

50 MWe (NET) 2 STAGE FLASH BINARY

SALTON SEA KGRA, NILAND, CALIFORNIA

$300 F$ BRINE INJECTION TEMPERATURE, UNMODIFIED BRINE CAPACITY FACTOR 71\%

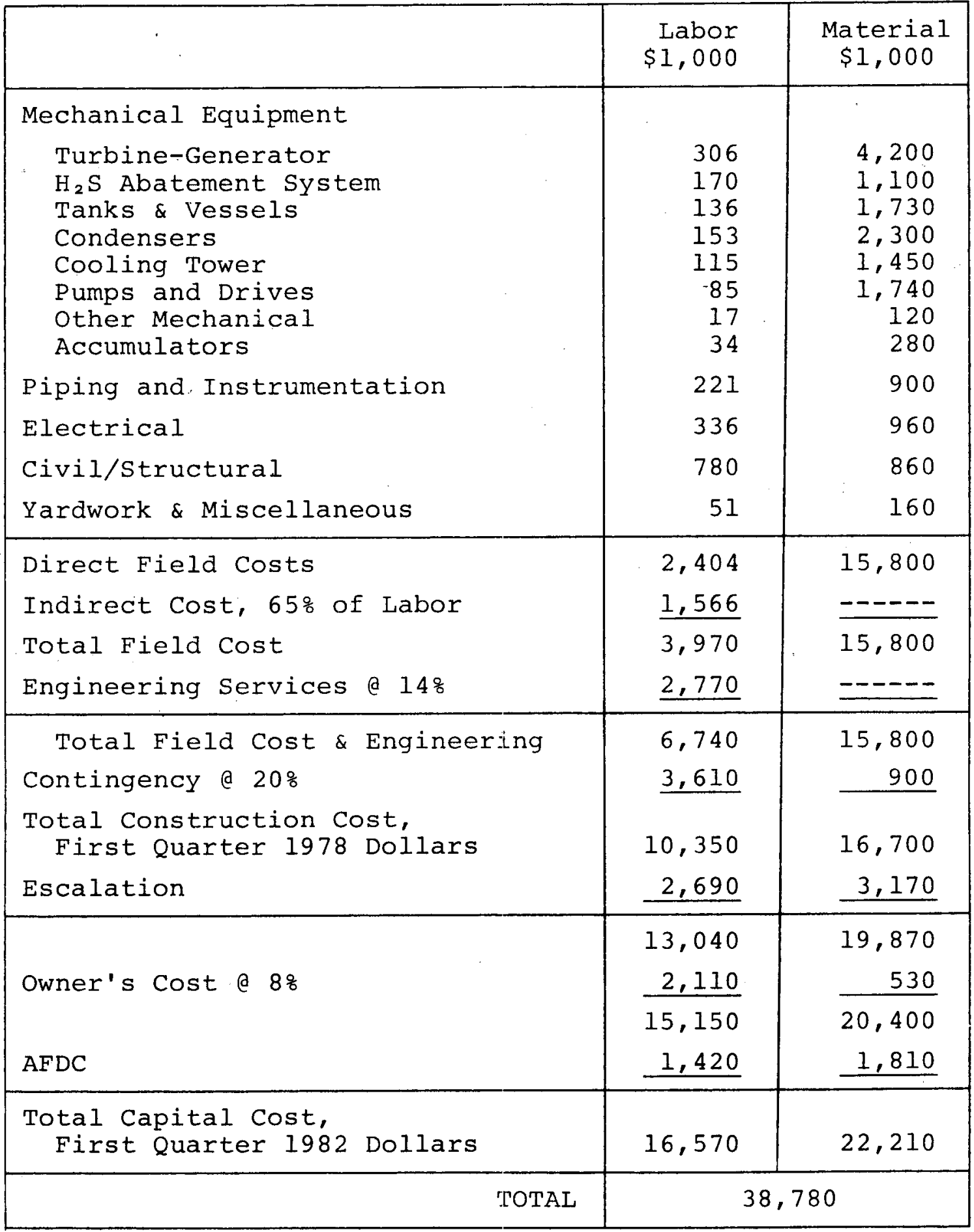


exchange binary estimate in Table 5-8. The four-stage with acid estimate is $\$ 40,350,000$, slightly higher than for the no acid use estimate of $\$ 39,540,000$. The difference is due to the use of alloy in the with-acid case. The estimated cost for the two-stage process, $\$ 38,780,000$, is lower than either of the four-stage cases because the simpler process requires less equipment. The estimated cost for the liquid/liquid heat exchange process is $\$ 43,700,000$, highest of the four processes considered. The high cost arises out of the more complex equipment requirements and the need for alloy.

\subsubsection{Capital cost of Well Fields}

The estimated capital costs of well fields for all four processes at the start of run are summarized in Table 5-9. Since 75 percent or more of the total cost is in the cost of the wells themselves, the well field cost is a strong function of the number of wells. Well field costs range from a low of $\$ 8,224,000$ for the liquid/liquid process at start of run to a high of $\$ 11,046,000$ for the two-stage process.

\subsubsection{Capacity Factors}

Plant on stream capacity factors are the same as for the flashed steam process; 85 percent for the acid treated brine cases and 71 percent for the unmodified brine cases. 
TABLE 5-8

CAPITAL COST ESTIMATE, POWER PLANT

50 MWe (NET) LIQUID/LIQUID HEAT EXCHANGE

SALTON SEA KGRA, NILAND, CALIFORNIA

NO MINIMUM BRINE INJECTION TEMPERATURE, ACIDIFIED BRINE CAPACITY FACTOR 85\%

\begin{tabular}{|c|c|c|}
\hline . & $\begin{array}{r}\text { Labor } \\
\$ 1,000\end{array}$ & $\begin{array}{c}\text { Material } \\
\quad \$ 1,000\end{array}$ \\
\hline \multicolumn{3}{|l|}{ Mechanical Equipment } \\
\hline $\begin{array}{l}\text { Turbine-Generator } \\
\mathrm{H}_{2} \mathrm{~S} \text { Abatement System } \\
\text { Tanks \& Vessels } \\
\text { Condensers } \\
\text { Cooling Tower } \\
\text { Pumps and Drives } \\
\text { Other Mechanical } \\
\text { Accumulators }\end{array}$ & $\begin{array}{r}306 \\
170 \\
190 \\
153 \\
115 \\
-68 \\
17 \\
34\end{array}$ & $\begin{array}{l}4,200 \\
1,100 \\
3,060 \\
2,300 \\
1,750 \\
1,600 \\
120 \\
400\end{array}$ \\
\hline Piping and. Instrumentation & 304 & 1,260 \\
\hline Electrical & 336 & 960 \\
\hline Civil/structural & 910 & 1,010 \\
\hline Yardwork \& Miscellaneous & 51 & 160 \\
\hline \multirow{4}{*}{$\begin{array}{l}\text { Direct Field Costs } \\
\text { Indirect Cost, } 65 \% \text { of Labor } \\
\text { Total Field Cost } \\
\text { Engineering Services a } 14 \%\end{array}$} & 2,654 & 17,920 \\
\hline & 1,726 & $z---\cdots$ \\
\hline & 4,380 & 17,920 \\
\hline & $\underline{3,120}$ & ------ \\
\hline \multirow{4}{*}{$\begin{array}{l}\text { Total Field Cost \& Engineering } \\
\text { Contingency \& } 20 \% \\
\text { Total Construction Cost, } \\
\quad \text { First Quarter } 1978 \text { Dollars } \\
\text { Escalation }\end{array}$} & 7,500 & 17,920 \\
\hline & $\underline{4,070}$ & 1,010 \\
\hline & 11,570 & 18,930 \\
\hline & 2,950 & 3,650 \\
\hline \multirow{3}{*}{ Owner's cost a $8 \%$} & 14,520 & 22,580 \\
\hline & 2,370 & 590 \\
\hline & 16,890 & 23,170 \\
\hline AFDC & 1,590 & 2,050 \\
\hline $\begin{array}{l}\text { Total Capital Cost, } \\
\text { First Quarter } 1982 \text {. Dollars }\end{array}$ & 18,480 & 25,220 \\
\hline TOTAL & & \\
\hline
\end{tabular}


TABLE 5-9

CAPITAL COST ESTIMATE, WELL FIELD

START-OF-RUN

50 MWe (NET) BINARY ENERGY CONVERSION

\begin{tabular}{|c|c|c|c|c|c|c|}
\hline & \multicolumn{2}{|c|}{$\begin{array}{l}\text { Liquid/Liquid } \\
\text { Exchange } \\
\$ 1,000\end{array}$} & \multicolumn{2}{|c|}{$\begin{array}{l}\text { Four-Stage } \\
\text { Flash } \\
\$ 1,000\end{array}$} & \multicolumn{2}{|c|}{$\begin{array}{l}\text { Two-stage } \\
\text { Flash } \\
\$ 1,000 \\
\end{array}$} \\
\hline & LABOR & MATERIAL & LABOR & MATERIAL & LABOR & MATERIAL \\
\hline $\begin{array}{l}\text { Brine Supply Lines } \\
\text { Materials \& Subcontracts } \\
\text { Installation } \\
\text { Brine Injection Lines } \\
\text { Materials \& Subcontracts } \\
\text { Installation }\end{array}$ & $\begin{array}{r}12 \\
173 \\
\end{array}$ & $\begin{array}{r}119 \\
- \\
627 \\
-\end{array}$ & $\begin{array}{r}8 \\
69 \\
12 \\
173 \\
\end{array}$ & $\begin{array}{r}137 \\
- \\
627 \\
- \\
\end{array}$ & $\begin{array}{r}9 \\
83 \\
14 \\
202 \\
\end{array}$ & $\begin{array}{r}165 \\
- \\
731 \\
-\end{array}$ \\
\hline $\begin{array}{l}\text { TOTAL FIELD COSTS OF LINES } \\
\text { Engineering, } 14 \%\end{array}$ & $\begin{array}{l}252 \\
140 \\
\end{array}$ & $\begin{array}{r}746 \\
- \\
\end{array}$ & $\begin{array}{l}262 \\
145\end{array}$ & $\begin{array}{r}764 \\
- \\
\end{array}$ & $\begin{array}{l}308 \\
169 \\
\end{array}$ & $\begin{array}{r}896 \\
- \\
\end{array}$ \\
\hline $\begin{array}{l}\text { TOTAL FIELD \& ENGINEERING } \\
\text { Contingency, } 20 \%\end{array}$ & $\begin{array}{l}392 \\
185 \\
\end{array}$ & $\begin{array}{r}746 \\
43 \\
\end{array}$ & $\begin{array}{l}407 \\
191\end{array}$ & $\begin{array}{r}764 \\
43 \\
\end{array}$ & $\begin{array}{l}477 \\
225 \\
\end{array}$ & $\begin{array}{r}896 \\
50 \\
\end{array}$ \\
\hline $\begin{array}{l}\text { TOTAL CONSTRUCTION COST OF } \\
\text { LINES (First Quarter 1978) } \\
\text { Geothermal Wells } \\
\text { (Subcontracts) }\end{array}$ & $\begin{array}{r}577 \\
1,785 \\
\end{array}$ & $\begin{array}{r}789 \\
3,315 \\
\end{array}$ & $\begin{array}{r}598 \\
1,995 \\
\end{array}$ & $\begin{array}{r}807 \\
3,705 \\
\end{array}$ & $\begin{array}{r}702 \\
2,380 \\
\end{array}$ & $\begin{array}{r}946 \\
4,420 \\
\end{array}$ \\
\hline $\begin{array}{l}\text { TOTAL CONSTRUCTION COST OF } \\
\text { WELL FIELD (First Quarter } \\
\text { 1978) } \\
\text { ESCALATION }\end{array}$ & $\begin{array}{r}2,362 \\
622 \\
\end{array}$ & $\begin{array}{r}4,104 \\
778 \\
\end{array}$ & $\begin{array}{r}2,593 \\
683 \\
\end{array}$ & $\begin{array}{r}4,512 \\
855 \\
\end{array}$ & $\begin{array}{r}3,082 \\
895 \\
\end{array}$ & $\begin{array}{l}5,366 \\
1,215 \\
\end{array}$ \\
\hline $\begin{array}{l}\text { CONSTRUCTION COST PLUS } \\
\text { ESCALATION } \\
\text { AFDC }\end{array}$ & $\begin{array}{r}2,984 \\
133 \\
\end{array}$ & $\begin{array}{r}4,882 \\
225 \\
\end{array}$ & $\begin{array}{r}3,276 \\
151 \\
\end{array}$ & $\begin{array}{r}5,367 \\
248 \\
\end{array}$ & $\begin{array}{r}3,977 \\
184 \\
\end{array}$ & $\begin{array}{r}6,581 \\
304 \\
\end{array}$ \\
\hline $\begin{array}{l}\text { TOTAL CAPITAL COST } \\
\text { (First Quarter 1982) }\end{array}$ & 3,117 & 5,107 & 3,427 & 5,615 & 4,161 & 6,885 \\
\hline TOTAL & \multicolumn{2}{|c|}{8,224} & \multicolumn{2}{|c|}{9,042} & \multicolumn{2}{|c|}{11,046} \\
\hline $\begin{array}{l}\text { Production Wells } \\
\text { Injection wells }\end{array}$ & \multicolumn{2}{|c|}{$\begin{array}{r}13 \\
6\end{array}$} & \multicolumn{2}{|c|}{$\begin{array}{r}15 \\
6\end{array}$} & \multicolumn{2}{|c|}{$\begin{array}{r}18 \\
7\end{array}$} \\
\hline
\end{tabular}




\subsubsection{Energy Production Costs}

Estimated energy production costs are summarized in Table 5-10. The lowest cost, $38.7 \mathrm{mills} / \mathrm{kWh}$, is achieved by both the Iiguid/ liquid heat exchange process and the four-stage process with acidified brine. The higher capital cost has been more than offset by higher thermal efficiency. The liquid/liquid process depends on the ability to use shell-and-tube heat exchangers for transferring heat from acidified brine. This operation has not been demonstrated and, therefore, the process has a high technical risk. Also, the capital cost for the liquid/liquid process is the highest of the four binary processes. Thus, the four-stage process with acidified brine is the process to be compared with the flashed steam process.

The four-stage process without acid shows an estimated cost of $43.7 \mathrm{mills} / \mathrm{kWh}$, a marked increase over the acidified brine case. The increase can be attributed, for the most part, to a lower capacity factor. The highest estimated energy production cost is for the two-stage flash process, which suffers from both a low capacity factor and a low brine utilization efficiency. 
TABLE 5-10

ENERGY PRODUCTION COST ESTIMATES

50 MWe (NET) BINARY ENERGY CONVERSION

SALTON SEA KGRA NILAND, CALIFORNIA

\begin{tabular}{|c|c|c|c|c|}
\hline & \multicolumn{3}{|c|}{ FLASHED BINARY } & \multirow{2}{*}{$\begin{array}{c}\text { Binary } \\
\text { with Liquid/ } \\
\text { Liquid Hx } \\
\text { mills/kWh } \\
\end{array}$} \\
\hline & $\begin{array}{l}\text { With Acid } \\
\text { mills } / \mathrm{kWh}\end{array}$ & $\begin{array}{l}\text { No Acid } \\
\text { mills/kWh }\end{array}$ & $\begin{array}{l}\text { Injection } \\
\text { at } 300 \mathrm{~F} \\
\mathrm{mills} / \mathrm{kWh}\end{array}$ & \\
\hline CAPACITY FACTOR, $\frac{\circ}{8}$ & 85 & 71 & 71 & 85 \\
\hline POWER PLANT & & & & \\
\hline Depreciation & 3.6 & 4.2 & 4.1 & 3.9 \\
\hline $\begin{array}{l}\text { Return on } \\
\text { Investment }\end{array}$ & 8.8 & 10.3 & 10.1 & 9.5 \\
\hline $\begin{array}{l}\text { Income Tax and } \\
\text { Ad Valorem Tax }\end{array}$ & 5.9 & 6.9 & 6.7 & 6.3 \\
\hline Plant Insurance & 0.1 & 0.1 & 0.1 & 0.1 \\
\hline $\begin{array}{l}\text { Operation \& } \\
\text { Maintenance }\end{array}$ & 3.5 & 2.7 & 1.4 & 3.4 \\
\hline $\begin{array}{l}\text { Administration } \\
\text { and General }\end{array}$ & 0.9 & 0.7 & 0.4 & 0.9 \\
\hline $\begin{array}{l}\text { TOTAL - POWER } \\
\text { PLANT COST }\end{array}$ & 22.8 & 24.9 & 22.8 & 24.1 \\
\hline WELL FIELD & & & & \\
\hline Depreciation & 0.8 & 1.0 & 1.2 & 0.7 \\
\hline $\begin{array}{l}\text { Return on } \\
\text { Investment }\end{array}$ & 4.1 & 4.9 & 6.0 & 3.7 \\
\hline Income Tax. & 3.5 & 4.1 & 5.0 & 3.1 \\
\hline Ad Valorem Tax & 1.6 & 1.9 & 2.4 & 1.5 \\
\hline $\begin{array}{l}\text { Operation \& } \\
\text { Maintenance }\end{array}$ & 2.5 & 3.0 & 4.3 & 2.5 \\
\hline $\begin{array}{l}\text { Production Well } \\
\text { Replacement }\end{array}$ & 1.2 & 1.4 & 1.7 & 1.0 \\
\hline $\begin{array}{l}\text { Injection well } \\
\text { Replacement }\end{array}$ & 0.3 & 0.3 & 0.4 & 0.3 \\
\hline $\begin{array}{l}\text { Administration } \\
\text { and General }\end{array}$ & 0.3 & 0.3 & 0.4 & 0.3 \\
\hline Royalties & 1.6 & 1.9 & 2.4 & 1.5 \\
\hline $\begin{array}{l}\text { TOTAL - WELL } \\
\text { FIELD COST }\end{array}$ & 15.9 & 18.8 & 23.8 & 14.6 \\
\hline $\begin{array}{l}\text { TOTAL - ENERGY } \\
\text { COST }\end{array}$ & 38.7 & 43.7 & 46.6 & 3.8 .7 \\
\hline
\end{tabular}




\section{Section 6}

\section{COMPARISONS}

Binary processes are in general somewhat more efficient than the dual flash steam process; they require less brine for a given net power output. The improved efficiency is, however, achieved at the expense of additional equipment. The choice of process depends on whether or not the additional equipment and power plant capital costs are justified by the reduction in brine requirements and well field capital costs. The flashed steam process is superior on the basis of estimated capital cost. Within the accuracy of the estimates, the energy production cost is the same. In addition, technical risks are probably somewhat less for the flashed steam process; the large hydrocarbon turbines specified for the binary process are not currently in commercial use, and the hydrocarbons present a potential fire hazard. Thus, the flashed steam process should be selected for the next phase of work at the GLEF. The binary processes should not be completely abandoned, however, since the potential for significant advantages exists.

\subsection{TECHNICAL}

Table 6-1 presents a summary of some of the plant performance values for both flashed steam and binary processes. As shown 
TABLE 6-1

PLANT PERFORMANCE COMPARISON

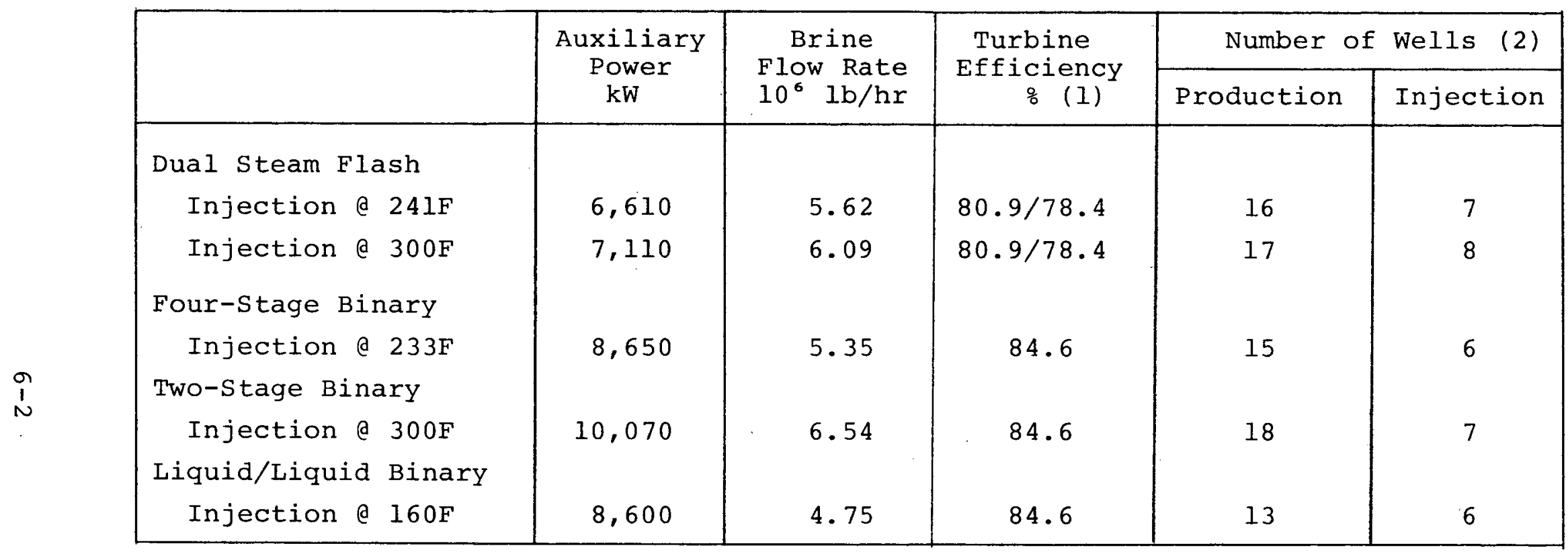

(1) Includes mechanical drive.

(2) Start of run. 
in the table, the auxiliary power requirements for the flashed steam processes are less than for the binary processes. The differences are primarily due to the power requirements of the hydrocarbon circulation pumps used in binary processes.

Brine flow rates for 50 MWe net power output, on the other hand, are less for binary processes. Steam turbine characteristics lead to the choice of two stages of steam flashing, which limits the ability of the process to extract heat from the brine. The brine rejection temperature for the dual steam flash process is $241 \mathrm{~F}$ as compared to $160 \mathrm{~F}$ for the liquid/liquid binary. Turbine efficiencies also favor the binary process. Commercial hydrocarbon turbines designed with due regard to overall economics characteristically have higher efficiencies than those designed for use with steam.

The large hydrocarbon turbines specified for the binary process are not currently in commercial use. Smaller, commercially tested hydrocarbon turbines are available, and manufacturers claim that the larger units are within the state of the art. However, large sized hydrocarbon turbines do not have the demonstrated reliability of large steam turbines.

The hydrocarbons used in the binary process present a potential fire hazard. This hazard should be somewhat less than that normally encountered in existing facilities such as petroleum 
refineries since the hydrocarbon is contained in a closed loop system. Also, the techniques for assuring safety are well developed and experience shows that hydrocarbons can be handled safely. On the other hand, a significant hazard does exist.

\subsection{OPERATION AND MAINTENANCE}

The brine handling portions of steam flash and binary processes are the same except for the liquid/liquid binary. Since brine handling is expected to provide the majority of operation and maintenance problems, the two types of processes should be quite similar in this respect. The liquid/liquid binary process, however, depends on the successful handling of brine in shelland-tube heat exchangers. Although significant scale control has been demonstrated by using acid, significant risk remains with this process.

Although operations and maintenance should be somewhat similar for both types of process, the steam flash processes can be expected to have some advantages. Steam flash processes use fewer pieces of equipment and steam turbines are relatively trouble free. On the other hand, the turbine loop in binary processes is closed; acid gases from the brine do not enter the turbine. 


\subsection{CAPITAL COSTS}

The increased efficiency of the binary process is achieved at the expense of higher power plant capital costs. While well field costs are reduced, the total capital cost for the binary processes are higher than for the corresponding flashed steam processes.

In this study the minimum energy production cost for binary processes is obtained with acid modified brine, no minimum injection temperature, and a four-stage flash. Total capital cost is 49.4 millions of dollars while the capital cost for the comparable flashed steam process is $\$ 48.0$ millions. Table 6-2 is a summary of capital costs.

$$
\text { TABLE } 6-2
$$

TOTAL CAPITAL COST

\begin{tabular}{|l|r|}
\hline & $10^{6} \$$ \\
\cline { 2 - 2 } BINARY PROCESS & \\
Four-Stage Flash, Acidified Brine & 49.4 \\
Four-Stage Flash, Unmodified Brine & 48.6 \\
Two-Stage Flash, Unmodified Brine, & 49.8 \\
300F Injection & 51.9 \\
Liquid/Liquid, Acidified Brine & \\
FLASHED STEAM PROCESS & 48.0 \\
No Limit, Acidified Brine & 47.0 \\
No Limit, Unmodified Brine Parallel Trains & 48.2 \\
No Limit, Unmodified Brine, Parad & 50.1 \\
300F Injection, Acidified Brine & 48.0 \\
300F Injection, Unmodified Brine & \\
\hline
\end{tabular}




\section{4}

ENERGY PRODUCTION COSTS

Table 6-3 presents a comparison of estimated energy production costs. As would be expected from the relative capital costs, the power plant costs per unit of produced power are higher for the binary processes than for the flashed steam. Well field costs per unit of power are, on the other hand, less for the binary processes. The lower well field costs for comparable cases are a reflection of the lower brine requirements for the binary processes. Total energy costs for comparable cases are essentially the same. The lowest cost for the binary processes is $38.7 \mathrm{mills} / \mathrm{kWh}$; the comparable cost for flashed steam is $38.5 \mathrm{mills} / \mathrm{kWh}$. A still lower cost, $37.6 \mathrm{mills} / \mathrm{kWh}$, was estimated for a flashed steam process using unmodified brine and parallel trains of equipment.

The estimates presented in this report are probably somewhat better than normal for the level of design detail that was delineated since they are based in part on more detailed conceptual work from other projects.

However, it is not realistic to expect an accuracy better than that which is based on general industrial experience in preparing conceptual design studies and corresponding cost estimates.

Since the same ground rules were used for all estimates, the relative values should be more reliable. That is, 
TABLE 6-3

COMPARISON OF ENERGY PRODUCTION COSTS

\begin{tabular}{|c|c|c|c|}
\hline \multirow[b]{2}{*}{ PROCESS } & \multicolumn{3}{|c|}{ ESTIMATED COST, $\mathrm{mills} / \mathrm{kWh}$} \\
\hline & $\overline{\text { PLANT }}$ & WELL FIELD & TOTAL \\
\hline BINARY PROCESS & & & \\
\hline $\begin{array}{l}\text { Four-Stage Flash, } \\
\text { Acidified Brine }\end{array}$ & 22.8 & 15.9 & 38.7 \\
\hline $\begin{array}{l}\text { Four-Stage Flash, } \\
\text { Unmodified Brine }\end{array}$ & 24.9 & 18.8 & 43.7 \\
\hline $\begin{array}{l}\text { Two-Stage Flash, } \\
\text { Unmodified Brine, } \\
300 F \text { Injection }\end{array}$ & 22.8 & 23.8 & 46.6 \\
\hline $\begin{array}{l}\text { Liquid/Liquid, } \\
\text { Acidified Brine }\end{array}$ & 24.1 & 14.6 & 38.7 \\
\hline FLASHED STEAM PROCESS & & & \\
\hline $\begin{array}{l}\text { No Limit, } \\
\text { Acidified Brine }\end{array}$ & 21.2 & 17.3 & 38.5 \\
\hline $\begin{array}{l}\text { No Limit, } \\
\text { Unmodified Brine }\end{array}$ & 23.5 & 20.6 & 44.1 \\
\hline $\begin{array}{l}\text { No Limit, Unmod. Brine } \\
\text { Redundant Flash Vessels }\end{array}$ & 20.3 & 17.3 & 37.6 \\
\hline $\begin{array}{l}300 \mathrm{~F} \text { Injection, } \\
\text { Acidified Brine }\end{array}$ & 25.3 & 24.0 & 49.3 \\
\hline $\begin{array}{l}300 F \text { Injection, } \\
\text { Unmodified Brine }\end{array}$ & 22.6 & 24.0 & 46.6 \\
\hline
\end{tabular}


small differences in capital costs and energy production costs are probably meaningful.

These differences are, of course, in part, a reflection of the design parameters used in developing the process design.

The flashed steam process is superior on the basis of estimated capital cost, which may be a consideration for future development. Within the accuracy of the estimates, the energy production cost is the same. Technical risks are probably somewhat less for the flashed steam process, in particular those associated with brine handling. Two stages would present less problems than four, and the cost of redundant flash vessel trains would be less. In addition, existing geothermal steam flash power plants have demonstrated that low cost electrical power can be produced commercially with this process. Investor confidence is, therefore, much higher for the flashed steam process than for the commercially untried flashed binary process. Thus, the flashed steam process should be selected for further work at the GLEF. The binary processes are, however, generally more efficient; and a potential for substantial technical improvement exists. Therefore, the binary processes should not be completely abandoned. 
Section 7

RISK ANALYSES

The following risk analyses have been limited to only those risks that are of major concern at this point in the development of the project. These risks affect the basic go or no-go decisions and are common to both flashed steam and flash binary processes. Other risks, though important, are apt to be reflected in only qualitative changes in the decision making process. The discussion of risk has been divided into three major sections, Reservoir Characteristics - Production, Power Plant, and Reservoir Characteristics - Injection. However, to facilitate reference, the individual risks from all three sections are numbered consecutively as indicated in the following pages.

Brine handling is the most important of the risk items. If satisfactory means can be found for producing the brine, carrying it through the plant and reinjecting it, the project will have a very high probability of success. The major problems in brine handing involve scale formation and corrosion.

\subsection{RESERVOIR CHARACTERISTICS - PRODUCTION}

Data Base. A number of production wells have been drilled in the salton sea KGRA, but none have been produced continuously for periods long enough to establish complete reservoir characteristics: On the other hand, a substantial resource is known 
to exist. Estimates vary, but one such estimate of 400 MWe for 20 years is probably reasonable. The reservoir contains highly saline, high temperature brine; and suitable downhole pumps are not available that are capable of handling the brine. The wells are, therefore, produced as self-flowing with flashing in the wellbore.

(1) Downhole Temperature. An initial downhole temperature of $500 F$ was used in the feasibility study and this is probably a reasonable estimate of the temperatures available. Reported temperatures vary from below $300 \mathrm{~F}$ to $680 \mathrm{~F}$ and temperatures as high as $750 \mathrm{~F}$ are projected for depths of 4,000 feet. A reasonable working range might be $400 \mathrm{~F}$ to $600 \mathrm{~F}$.

(2) Production Rate. The production rate for a given selfflowing well is a function of wellhead pressure. The flow rate increases as the wellhead pressure is lowered until a maximum is reached that is set by reservoir permeability, casing slotted area, or sonic velocity. Increasing wellhead pressure eventually causes the flow to stop. Wells will normally be produced at less than maximum rate to avoid lowering the wellhead temperature excessively and to avoid excessive flashing. The start-of-run flow rate used for the feasibility study was $400,000 \mathrm{lbs} / \mathrm{hr}$ per well, a figure that has been matched at the GLEF. Reported flow rates vary from 172,000 to $625,000 \mathrm{lbs} / \mathrm{hr}$ per well, with a reasonable expected range of 200,000 to $500,000 \mathrm{lbs} / \mathrm{hr}$.

(3) Noncondensible Gas. Salton sea brines are known to contain noncondensible gases, but there are no reliable data on the amount. Carbon dioxide has been produced commercially from shallow wells in the KGRA; on the other hand, recent GLEF data show a gas content of 0.1 weight percent. A value of 0.5 weight percent was used in the feasibility study.

The gas is primarily carbon dioxide with minor amounts of methane, hydrogen and hydrogen sulfide. The hydrogen sulfide, important from an air pollution standpoint, was assumed to be $820 \mathrm{ppm}$ by volume of the noncondensible gas. One set of experimental values gave $500 \mathrm{ppm}$ for Woolsey \#l and $1,800 \mathrm{ppm}$ for Magmamax \#1.

(4) Brine Composition. The brines in the Salton Sea KGRA are highly saline, with reported total dissolved solids content 
(TDS) of 3.6 to 38.8 weight percent. The major constituents are sodium, potassium and calcjum chlorides; with minor amounts of heavy metals, carbonates and sulfates. The brines also contain dissolved silica and are probably near saturation with respect to silica at downhole conditions. A TDS content of 20 weight percent was used for the study, and the solids were assumed to be sodium chloride for purposes of thermodynamic calculations.

(5) Corrosion. The salton sea geothermal brines are known to be highly corrosive to steel in the presence of air, which would be expected on the basis of their chemical composition. The amount of corrosion to be expected in the absence of air is, however, very much open to question. Visual inspection of wellhead equipment has, in some cases at least, shown little evidence of corrosion. On the other hand, corrosion has been observed in well casing and brine handling equipment where air was assumed to be absent. For the study, a corrosion allowance of 1/4-inch was used for production well piping. The cements used in well completion may also be subject to corrosion. Laboratory tests have shown that some commonily used cements are attacked by simulated brines.

(6) Scale. The formation of scale has been observed in production well casing and piping, but does not appear to be a serious problem with normal production. That serious scaling can occur is demonstrated by the experience with Sinclair \# 1 near Niland. The well was abandoned after four months operation due to scaling of the well at the surface. Other wells have been operated successfully for much longer periods, however, with no apparent scaling. It may be that limiting the amount of flashing in the well is a satisfactory method for controlling scale formation in the well. A scaling rate of $70 \mathrm{mils} /$ year for production piping was assumed for the study.

(7) Well Decline. There are no test data that show a clear temperature and/or production rate decline as a function of time for wells in the Salton Sea KGRA. There are theoretical reasons to expect a temperature decline as a well is produced, though the magnitude of the effect cannot be accurately predicted. Since the wells are self-flowing, a temperature decline can be effected to result in a production rate decline for a constant wellhead pressure. A temperature decline rate of $18 \mathrm{~F}$ in 30 years was used in the study. It was also assumed that the production rate would drop from $400,000 \mathrm{lbs} / \mathrm{hr}$ to $300,000 \mathrm{lbs} / \mathrm{hr}$ over the same time span.

(8) Brine Compatibility. Brine chemistry varies from well to well and it is possible that brines from widely spaced wells 
might not be compatible. Mixing such brines might lead to the precipitation of solids and high scaling rates. Mixing brines with other liquids may also present problems. This would be particularly important, for example, if it proved to be desirable to mix water from the salton sea with reject brine to maintain injection volume. In the GLEF, mixing first stage condensate with flashed brine leads to scale formation, but very little other information on brine mixing is available.

(9) Well Layout. Wells must be properly spaced. Too close a spacing will result in the drilling of more wells than are needed and a posisible reduction in production rate per well. Too wide a spacing increases the length and size of production piping and may lower the potential yield of geothermal fluid. Optimum spacing is not known, but estimates can be made on the basis of limited field experience and theoretical analysis. The study assumes 600 to 700 foot bottom-hole spacing for 4,000 foot deep wells with slant drilling, so that wellheads will be in two rows 150 feet apart with 50 foot spacing within rows.

The location of production wells relative to injection wells is also important. There must be enough space to prevent short circuiting, but subsidence and stresses within the reservoir should be avoided. For the study, the distance between the production well island and the injection well island is about 3,000 feet.

(10) Subsidence. Ground subsidence due to natural causes has been observed in the area. The withdrawal of large volumes of brine without reinjection can, from theory, be expected to increase subsidence. It has been assumed that reinjecting spent brine will prevent subsidence, but whether replacement on a volume per volume basis is required and how the brine should be reinjected is not known with certainty.

Analysis. The existence of an adequate resource is an obvious requisite for a successful geothermal power project. There is little doubt, however, that the reservoir is adequate for a 50 MWe power plant as a minimum; thus, the existence of an adequate resource is a low risk item. Enough production wells have been drilled and operated to demonstrate the technical 
feasibility of delivering brine to a power plant; so brine production is low risk, insofar as the technical ability to do so is concerned.

The important risks associated with reservoir characteristics and brine production are economic or environmental in nature. That is, the existence of an adequate energy source and the ability to deliver brine have been reasonably well established; the ability to deliver the brine at an acceptable cost has not been demonstrated.

(1) Downhole Temperature. The temperature at which geothermal energy is available has a direct and strong influence on the efficiency of the power plant. This, in turn, affects the brine production rate required for a given net power output and the capital and operating costs of both the plant and well field. A 50 MWe power plant has been proposed for Heber where the brine temperature is 360F, substantially lower than the 500F assumed for Niland. Considering temperature only, the risk of an uneconomical project caused by a lower than expected temperature is low.

(2) Production Rate. Brine production rate per well sets the number of wells needed to provide the brine for a power plant, other factors being equal. As a rough approximation, the capital cost of the well field is directly proportional to the number of wells; operating costs also increase with an increase in number of wells, but not proportionally. Since total well field cost accounts for approximately half of total energy production cost, decreasing brine production rate per well by a factor of 2 will increase total energy cost by roughly 25 percent. Although this would be a substantial increase in cost and a brine rate of half that expected is possible, such an event is not very probable; and the risk is judged to be moderate.

(3) Noncondensible Gas. The amount of noncondensible gas has a strong influence on the choice of power plant process. If the noncondensible content of the brine were to increase 
substantially over the assumed 0.5 weight percent, say to 3 percent, the flashed binary process would be favored over the flashed steam process. Since this would only marginally affect the estimated cost of energy, the risk is felt to be low.

The amount of hydrogen sulfide in the gas has an influence on the type of air pollution abatement equipment needed, and thus on capital and operating costs. The complex and expensive system assumed for the study accounts for about 9 percent of the plant capital cost. Eliminating the system entirely might reduce energy cost by as much as 5 percent. The risk for this item is low.

(4) Brine Composition. The brines are known to be highly saline, with high total solids and silica contents. There is a reasonable amount of data available on the compositions of brines from various parts of the KGRA and substantial differences in behavior due to variations in composition are not anticipated. The risk is low.

(5) Corrosion. It is highly probable that suitable metallurgy can be found to protect against corrosion in the well casing and wellhead piping. The difficulty is that information is not available; carbon steel may be satisfactory or a more expensive alloy may be required. Experience to date indicates that there is a reasonable chance that carbon steel will be satisfactory. on the other hand, even mild alloy requirements for well casing could add substantially to well field costs. Little information is available on the corrosion of cements by brine. The risk is estimated to be moderate.

(6) Scale. It is likely that scale formation in the well casing and wellhead piping is associated with flashing. It should be possible to operate the wells satisfactorily with limited flashing and thus avoid excessive scale. The amount of scale observed in wellhead piping seems to be substantially Iess than that after the first stage flash and the corresponding problems should be less. If a satisfactory solution can be found for the plant, the well field piping should provide no special problem. The risk is felt to be moderate.

(7) Well Decline. New wells will be needed during the life of the project. The number needed depends on the rate at which downhole temperature and production rate decline. The number of spare wells needed will also be influenced by the well decline characteristics. If the rate of decline is slow and predictable, fewer spare wells will be required 
than if wells are subject to unpredictable rapid decline. Since the cost of the wells is about 75 percent of the total well field capital cost, the number of wells is obviously important. Total well field cost accounts for roughly half of the total energy production cost, so increasing the number of wells by 10 percent would increase total energy production costs by on the order of 4 percent. Although there is no clear evidence to establish decline rates, the risk is judged to be moderate.

(8) Brine Compatibility. Although brine chemistry varies from well to well; the chemistry is, in general, similar. Differences in scaling rates and corrosion for mixtures of brine would be expected to be only marginally different than for the component brines. The risk associated with mixing brines should be low. Mixing reject brine with other water, such as water from the Salton sea, is more apt to result in major changes in scale forming and corrosion characteristics. No information is available on the magnitude or direction of the possible changes. On the other hand, it is probable that suitable methods for treating the water can be developed and the risk is judged to be low.

(9) Well Layout. Weli layout problems are difficult to resolve. The use of theory, though valuable, is limited and the operation of large well fields is too expensive unless associated with a commercial plant. It is reasonable to assume that a satisfactory well layout can be developed; however, if this is not the case, the project will fail. The risk is judged to be low.

(10) Subsidence. Natural subsidence is occurring in the area and withdrawal of liquids has been known to cause subsidence in other areas. It is reasonable, therefore, to expect additional subsidence to occur if brine is withdrawn and not reinjected. Reinjection of equal volumes as compared to the volumes withdrawn would probably prevent additional subsidence, if reinjection is done properly. The requirements for "proper" reinjection are not completely known and the area is very sensitive to the effects of subsidence: the risk is judged to be moderate.

\subsection{POWER PLANT}

Data Base. The GLEF has been operated for a total period in excess of 4,500 hours and as much as 900 hours continuously. 
Run time with the present plant configuration appears to be limited to about 1,000 hours before shutdown is forced by scale formation. Surging, probably related to two-phase flow, interferes with flow and level control and makes it difficult to achieve steady state operation. Scale formation interferes with the operation of control valves and instrumentation so that reliable data cannot be obtained. The injection pump is also subject to scaling, causing pump failure and plant shutdown. Although progress has been made towards solving these problems; steady, reliable operation with these brines has not been demonstrated.

(11) Scale. Heavy scaling has been observed throughout the plant, but the rate of scaling and the character of the scale are varible. The parameters that appear to be important in scale formation are brine composition, temperature, $\mathrm{pH}$, time, and flow conditions; the relationships are not fully understood. In general, scaling increases with a decrease in temperature, presumably because of the lowering of solubility. Limited test results show that scaling can be decreased substantially by acidifying the brine. The formation of silica scale is time dependent; scale formation can be displaced long distances in the equipment and piping after a change in temperature, $\mathrm{pH}$, or brine composition has been established. The thickness and hardness of the scale formed seems to depend on flow velocity. Scale formed in regions of high velocity appears to be thinner and harder than that formed in adjacent regions of lower velocity. Recombining condensate with brine leads to the formation of carbonate scale, changing the amount and character of scale formed in the following flash stages.

A scaling rate of $1 \mathrm{mil} / \mathrm{hr}$ was used in the feasibility study for unmodified brine. The observed scaling rates, however, vary widely with location and operating conditions and are not completely predictable. Scale thickness in the vapor space of the flash vessels is very much 
less than in the brine, in some cases by a factor of 10 . Although rates in the brine for a given location may vary by a factor of 5 from run to run, the following rates by flash stage are probably representative: first stage l.I mils/hr, second stage $2.2 \mathrm{mils} / \mathrm{hr}$, third stage $1.0 \mathrm{mil} / \mathrm{hr}$, fourth stage $2.2 \mathrm{mils} / \mathrm{hr}$. Scaling in the injection line is also variable, but a typical rate is about $1.5 \mathrm{mils} / \mathrm{hr}$. In general, the first stage scale is predominantly a fairly hard, heavy metal sulfide while the final stages are predominantly a softer silica scale. Hard carbonate scale can form where condensate is recombined with brine. Suspended solids content tends to increase as the brine flows through the plant.

(12) Corrosion. Corrosion of carbon steel in both vapor and brine areas has been observed in the GLEF. Part of the corrosion undoubtedly occurs when the unit is opened to the air, but it appears that substantial corrosion also occurs during air-free operation. Corrosion rate data are not available from the plant, particularly for airfree operation. Some preliminary data for tests with acidified brine show corrosion rates for 1018 steel in $\mathrm{pH} 4$ brine as follows: $210 \mathrm{C}$ is $80 \mathrm{mils} / \mathrm{yr}, 150 \mathrm{C}$ is 22 $\mathrm{mils} / \mathrm{yr}$, and $125 \mathrm{C}$ is $18 \mathrm{mils} / \mathrm{yr}$. Corrosion rates for unmodified brines should be lower, and scale should provide some corrosion protection; reliable data are, however, not available.

(13) Two-Phase Flow. Surging flow from the production wells has been a source of operating problems at the GLEF. The surging is probably caused by unstable two-phase flow in the piping between the well and the plant. No satisfactory calculation methods exist to accurately predict the behavior of brine-steam mixtures, and it might not be possible to design a single line that would provide stable two-phase flow over a reasonably wide range of flow rates.

(14) Steam Quality. The scrubbers at the GLEF have at times produced steam with less than $10 \mathrm{ppm}$ total dissolved solids. There are insufficient data, however, to use as the basis for predicting the behavior of the scrubbers over a reasonably wide range of operating conditions. Also, realistic steam quality requirements have not been established for the steam turbines.

(15) Noncondensible Gas. The noncondensible gas content of the brines being supplied to the GLEF is lower than originally expected; now in the range of 0.1 to 0.5 weight percent. The gas content of other wells in the KGRA has not been 
established, and the variability to be expected is not known. Analyses of the noncondensible gas from the first stage at the GLEF show 550 and 1,800 ppm by volume hydrogen sulfide.

(16) Waste Disposal. Estimates based on GLEF data show that about $3,000 \mathrm{lbs} / \mathrm{hr}$ or solids will have to be disposed of in a 50 MWe plant. For the feasibility study, it was assumed that hauling the solids to a dump site would be an environmentally and economically acceptable solution. It is not known whether or not this solution would be acceptable or optimum for a commercial plant.

Liquid wastes, in particular cooling tower blowdown will also present a disposal problem. Long term disposal to the Salton sea may not be acceptable. It is not known whether these liquid wastes are compatible with reject brine so that they could be injected with the brine.

(17) Equipment. Experience at the GLEF shows that the valves and pumps now being used foul with scale and fail. Control valves freeze within a few hundreds of hours and shutoff valves cannot be closed completely. The injection pump loses capacity, and its bearings fail. Pipeline scale seriously reduces flow capacity and can completely plug the lines.

(18) Instrumentation. Instrumentation has been a problem at the GLEF, mainly because of scale formation and surging. Scale formation seals off pressure taps and builds an insulating layer around thermowells so that pressure and temperature readings are invalid. Orifice plate openings are reduced by scale formation leading to inaccurate flow readings. scale thickness is sufficient to interfere with ultrasonic flowmeter operation.

(19) Water Availability. The long term availability of water now used for agriculture is not assured. Other sources of relatively fresh water not requiring extensive treatment do not seem to be available. Using steam condensate from the process for cooling tower makeup and other minor uses would solve the problem, if this use is otherwise acceptable.

(20) Brine Modification. Preliminary tests with brine modified by the addition of acid show a substantial decrease in scale formation rate, perhaps by as much as a factor of 10 . Other methods, such as the addition of polymers, may also be effective in reducing scale formation. 
Analysis. Scale formation has been the most important impediment to the steady reliable operation of the GLEF. An economical solution to the scaling problem for a commercial plant would go a long way toward assuring commercial success. The corrosion problem has not been adequately defined, but is probably not serious from a technical point of view. If expensive alloys are required, this will be reflected in both capital and energy costs; but economic viability should be affected only marginally. Other risk items present a substantially lower level of risk.

(11) Scale. The rate of scale formation is very high as compared to that usually encountered in commercial plants, and scale presents a very serious operating problem. The methods for dealing with scale that have been developed at the GLEF have been only partially successful. It is probable that methods can be developed that will answer the technical problems, but the costs may be substantial. It is particularly important that the solution to the problem includes achieving a high plant capacity factor; the energy production cost is, very roughly, inversely proportional to the plant capacity factor. As compared to other items, the risk is judged to be high.

(12) Corrosion. The corrosion problem has not been well defined. Once the requirements are known it should not be difficult to establish satisfactory materials specifications. However, depending on the severity of the corrosion problem, the cost of special materials may be substantial. Although it is not very likely that an otherwise attractive project would be defeated by corrosion, the impact on profitability could be substantial. The risk is felt to be high.

(13) Two-Phase Flow. Unstable two-phase flow has been a problem at the GLEF, particularly in that it interferes with obtaining satisfactory data. The problem may not seriously interfere with the production of power from a commercial plant. Avoiding unstable two-phase flow or designing to accommodate it appears to be a moderate technical risk. 
(14) Steam Quality. Although more information is needed on steam quality requirements and equipment performance, providing acceptable steam quality can be considered state of the art. The risk is low.

(15) Noncondensible Gas. More information is needed on the noncondensible gas content of the brine, but the gas content appears to be lower than originally expected. Some form of pollution control equipment will be required because of the hydrogen sulfide present, and more information is needed for proper design. The risk for this item is, however, low.

(16) Waste Disposal. The problem of solids disposal needs further study, but should not present any insurmountable difficulties. In the feasibility study the cost of solids hauling was estimated to be about $0.5 \mathrm{mills} / \mathrm{kWh}$. Although this is not a firm figure, the cost could vary considerably without drastically affecting project economics.

Disposal of cooling tower blowdown could present a problem if it cannot be injected with the brine or sent to the salton sea. The costs of treatment methods for zero cooling tower blowdown are significant, but should not be economically unacceptable. Waste disposal is judged to be a low risk item.

(17) Equipment. Equipment problems are directly related to scaling and, to a lesser extent, corrosion problems. Suitable equipment does not appear to be available commercially. Methods for suitably modifying available equipment will have to be found, or new designs of equipment will have to be developed. The risk is judged to be high:

(18) Instrumentation. Instrumentation problems are directly related to scaling and, to a lesser extent, surging. Methods for protecting the primary sensors, or for cleaning them in place, will have to be developed. The risk is judged to be high.

(19) Water Availability. Water is needed for cooling tower makeup. Steam condensate appears to be a suitable source for this water, and will probably be available if it is not necessary to reinject it with spent brine. Agricultural water would also be acceptable, if available. Other sources would probably require expensive treatment and could affect the cost of power production appreciably, depending on the source. The risk is felt to be low. 
(20) Brine Modification. Brine modification presents an opportunity for improving performance and lowering costs. On the other hand, the project is probably not dependent on brine modification. The risk is low.

\subsection{RESERVOIR CHARACTERISTICS - INJECTION}

Data Base. The operation of injection wells as part of the GLEF activities has provided limited information on brine injectivity. Difficulties have been experienced since the start with increasing wellhead pressures and accompanying reductions in flow rate. The wells have not been capable of handling the design flow rate at design wellhead pressure. Plugging is known to occur in the slots of the casing, but the character and extent of possible formation plugging is unknown. Progress has been made toward development of a brine treatment process to remove suspended solids before injection, which should improve injectability.

(21) Injection Rate. Operation of the GLEF has not been steady and reliable enough to establish a long term injection rate. Well plugging, as evidenced by increasing wellhead pressure, does not occur at a constant rate. As an example, Magmamax \#3 was reworked in March 1977 and wellhead pressure increased relatively slowly during April, rising from 180 psig to about 230 psig. In the first half of May the pressure increased rapidly to 400 psig. Reworking the well decreases wellhead pressure, but may not fully restore it to its original value. The cause of the plugging is not well understood but is probably, at least partially, related to suspended solids. Removing the solids before injection may or may not eliminate plugging, however, since reactions might take place within the reservoir that lead to plugging. Limited core flushing tests indicate that brine with low suspended solids content might be injectable, and similar tests with acidified brine are even more encouraging.

(22) Scale. The scale formation observed in the injection line appears to continue at about the same rate in the well casing. Scale is particularly troublesome in the slotted area 
of the casing where it causes plugging. If the brine is pretreated by settling, or settling and filtration, the silica content appears to be reduced to saturation; scaling should be substantially reduced. The amount of scaling, if any, to be expected in the formation is unknown.

(23) Corrosion. Since brine is rejected at a relatively low temperature, corrosion should be less than in production wells or the plant. Although the corrosion rate has not been established, visual inspection indicates little evidence of corrosion.

(24) Treatment. Treatment of the brine before injection appears to be justified. Experiments with settlers and clarifiers show that it is possible to reduce the suspended solids content of the brine from several hundred parts per million to below 50 parts per million; at the same time the silica content is reduced from supersaturation to approximately saturated values. Subsequent treatment by filtration can reduce the suspended solids content further, probably to less than 10 parts per million.

Some core flushing tests with acidified brine indicate that it might be possible to inject acidified brine without first neutralizing it; an advantage if the brine is to be acidified before entering the plant. In fact, the test results suggest that acidified brine might be easier to inject than unmodified brine.

(25) Well Decline. Experience at the GLEF has shown that wells can decline very rapidly in some circumstances. These rapid decline rates are probably not typical of what is to be expected from commercial operation, and are probably the result of high suspended solids loading or unusual scaling conditions. The decline rates to be expected, especially as a function of brine pretreatment, are unknown.

(26) Subsidence. The withdrawal of large volumes of brine without reinjection can be expected to increase the natural subsidence that has been observed. Although theory is helpful, sufficient information is not available as to the brine volume and placement needed to avoid subsidence.

(27) Brine Compatibility. If steam condensate is used for cooling tower makeup, it might be necessary to find another source of water to maintain reinjection volumes. Injection has also been considered as a means for disposal of liquid wastes. To be successful, the mixed liquids must be compatible; they should not react to form solids that can plug the injection wells, for example. Other than theory there is no information available on the subject. 
(28) Well Layout. As with production wells, optimum spacing and layout is not known. Limited field experience and theoretical analysis is helpful but not conclusive. For the study, an injection well island was located about 3,000 feet from the production well island.

Analysis. It has been reasonably well established that injection is the only practical way of handling the reject brine. That being the case, a satisfactory injection scheme is necessary to a successful geothermal power project. Injection has been demonstrated at the GLEF and progress is being made on reject brine treatment methods; however, successiul long term injection has not been demonstrated. In general, the technical, economic and environmental risks are high.

(21) Injection Rate. Injection rate per well sets the number of wells needed for a given sized power plant. Well field capital cost is, roughly, directly proportional to the number of wells; and operating costs also increase with the number of wells. As a very rough approximation, doubling the number of injection wells only, would increase the cost of energy produced by about 12 percent. This would be a substantial increase in cost and the useful rate over the life of a well is not known with reasonable accuracy; the risk is judged to be high.

(22) Scale. Scale in the casing and slots can cause plugging and maintenance problems, and can add significantly to costs. Less is known about the potential for scale or solids formation in the reservoir, but plugging in the reservoir could be even more serious. In spite of the progress being made in brine treatment methods, the risk is felt to be high.

(23) Corrosion. Corrosion in the injection wells appears to be potentially less serious than in the plant or production wells. The risk appears to be moderate.

(24) Treatment. Treatment of the brine before injection is being studied and the results are encouraging. On the other hand, developing a satisfactory injection scheme is critical to the success of the project; the risk is felt to be high. 
(25) Well Decline. Well decline rate sets the number of replacement wells required over the life of the project, or the frequency of major well reworking. The potential cost effects are substantial. Although it is reasonable to expect commercial experience to be better than that at the GLEF, the decline rate can not be accurately predicted with the information now available. The risks appear high.

(26) Subsidence. Naturally occurring subsidence has been observed in the area, and any addition to subsidence cannot be tolerated for environmental reasons. From theory, it seems probable that reinjecting the proper volume of brine in appropriate locations will prevent subsidence caused by withdrawing brine from the formation. The requirements are not well defined and the needed information will be difficult to obtain; however, the risk is judged to be moderate.

(27) Brine Compatibility. At this time the use of steam condensate for cooling tower makeup appears to be highly desirable. If the condensate is not available for reinjection, other sources of water may have to be used to maintain injected volume equal to produced volume. The other sources, for instance water from the salton sea, may not be compatible with reject brine or may require expensive pretreatment. Although the possible economic impact could be appreciable, the risk is felt to be moderate.

(28) Well Layout. Although optimum well layout is not known and the information needed to develop the optimum layout may be difficult to get, the risk is judged to be low.

7.4

RISK PRIORITIES

Risk priority and level of risk for each risk item are summarized in Table 7-1. The level is assessed separately for the areas of technical, economic, and environmental risks. An estimate is given as to whether the risk can be resolved by GLEF activities. The priorities assigned are intended as guidance for setting up GLEF activities. They are based on currently available information and can be expected to change as the project progresses. 
TABLE 7-1

RISKS

\begin{tabular}{|c|c|c|c|c|c|c|}
\hline \multirow{2}{*}{ ITEM } & \multirow{2}{*}{ No. } & \multicolumn{3}{|c|}{ LEVEL OF RISK } & \multirow{2}{*}{$\begin{array}{l}\text { GLEF CAN } \\
\text { RESOLVE }\end{array}$} & \multirow{2}{*}{$\begin{array}{c}\text { GLEF } \\
\text { PRIORITY }\end{array}$} \\
\hline & & TECHNICAL & ECONOMIC & ENVIRONMENTAL & & \\
\hline \multicolumn{7}{|l|}{ PRODUCTION } \\
\hline Downhole Temperature & 1 & Low & Low & - & Part & 23 \\
\hline Production Rate & 2 & Moderate & Moderate & - & Part & 10 \\
\hline Noncondensible Gas & 3 & Low & Low & Low & Part & 20 \\
\hline Corrosion & 5 & Moderate & Moderate & - & Yes & 13 \\
\hline Scale & 6 & Moderate & Moderate & - & Yes & 12 \\
\hline Well Decline & 7 & Moderate & Moderate & - & Part & 11 \\
\hline Brine Compatibility & 8 & Low & Low & - & Part & 14 \\
\hline We1l Layout & 9 & Low & Low & Low & No & 21 \\
\hline Subsidence & 10 & Low & Low & Moderate & No & 15 \\
\hline \multicolumn{7}{|l|}{ PLANT } \\
\hline Corrosion & 12 & Moderate & High & - & Yes & 2 \\
\hline Two-Phase Flow & 13 & Moderate & Low & - & Yes & 17 \\
\hline Steam Quality & 14 & Low & Low & - & Yes & 26 \\
\hline Noncondensible Gas & 15 & Low & Low & Low & Yes & 19 \\
\hline Waste Disposal & 16 & Low & Low & Low & Part & 24 \\
\hline Equipment & 17 & High & High & - & Yes & 3 \\
\hline Instrumentation & 18 & High & $\mathrm{High}$ & - & Yes & 4 \\
\hline Water Availability & 19 & Low & Low & Low & No & 25 \\
\hline Brine Modification & 20 & Low & Low & - & Yes & 28 \\
\hline \multicolumn{7}{|l|}{ INJECTION } \\
\hline Injection Rate & 21 & High & $\mathrm{High}$ & - & Part & 5 \\
\hline Scale & 22 & High & High & - & Yes & 8 \\
\hline Corrosion & 23 & Moderate & Moderate & - & Yes & 9 \\
\hline Treatment & 24 & High & High & - & Yes & 7 \\
\hline Well Decline & 25 & High & High & - & Part & 6 \\
\hline Well Layout & 28 & Low & Low & Low & No & 22 \\
\hline
\end{tabular}


section 8

RESEARCH AND DEVELOPMENT RECOMMENDATIONS

This section propose tests to be accomplished at the Geothermal Loop Experimental Facility (GLEF). These tests will address uncertainties to minimize the risks associated with the selected conceptual geothermal power plant design. As much of this information as possible is to be acquired during the 1978 calendar year.

The specific areas of investigation outlined in this section were selected in an effort to solve the potential problems enumerated in section 7. A number of the tests listed below will yield data applicable to the solution of more than one of these problems.

In addition to the GLEF tests" other activities are also included. These activities are risk studies that are intended to be made away from the test site either because the test equipment is not available at the site or because the study is not dependent on the test facility.

The primary objective of the modified test facility is to demonstrate the reliable operation of a two-stage flash system, over an extended period of time. The system includes the production wells, the power plant, and the infection wells. 


\subsection{RECOMMENDED GEOTHERMAL LOOP EXPERIMENTAL FACILITY (GLEF) ACTIVITIES}

8.1.1 Test Format

Each test description consists of the following:

- Priority. One of the two levels of priority that are described below has been assigned to each test:

A- Tests that establish operability and demonstrate high plant availability. These will furnish technical and economic data essential to minimizing the most important risks involved in the design and operation of a commercial 50 MWe geothermal power plant and its associated well field.

B- Tests directed towards reducing technical or economic uncertainties and optimizing plant performance.

Within each level of priority, the tests have been ranked in the order of their importance. The risk priorities correspond to those assigned to the risks in section 7. Tests under category $A$ have higher priority than those under Category $B$.

The requirement for continuous operation of the overall system was considered, in addition to the degreee of risk, in assigning priorities to the tests and in selecting the recommended procedures.

- Risk Area. The risk areas of section 7, to which the respective tests are related, are enumerated.

- Oblectives. The specific types of data to be accumulated, and their relationship to the ultimate goal of power plant design and operation, are indicated.

- Significance. This relates the risk areas and the tests associated with them to their influence on cycle efficiency. plant availability, longevity of equipment, reservoir life, cost of replacement parts and maintenance supplies, operation and maintenance labor, and environmental factors. 
- Alternative Procedures. The various methods that could be used to achieve the test objectives are discussed.

- Recommended Procedure. The specific alternative procedure(s) anticipated to yield the best information in the available time is recommended.

8. 1. 2 Test Assumptions

The conclusion of phase I of the feasibility study is that a Elash cycle is most appropriate for the initial development at the salton Sea RGRA. Therefore, the tests are directed towards this type of geothermal power plant.

The proposed tests assume that the existing GLEF will be modified to simulate a two-stage flash system with operating conditions as close as possible to those of the conceptual design. The modified test facility will include as much of the existing equipment as possible.

The existing system flashes geothermal brine from the wells into steam in four stages at progressively lower pressures and temperatures. The new facility will have two stages of flashing, preferably in two trains, so that parallel tests can be carried out or one train can be shut down for servicing and cleaning while the other remains in operation. Since a steam turbine is not available at the test facility, the flashed steam will continue to be condensed in the existing heat exchangers. The heat exchangers used for condensing the steam would continue to be cooled by a closed loop with water pumped from the spray pond. 
The steam condensate will be used as makeup for this cooling system. Noncondensible gases will continue to be removed after the first stage flash tanks by the existing vent gas separator. Brine production from two wells will be utilized in the facility. and the spent brine will be injected into one well after conditioning at the test facility in either settling tanks or a reactor-clarifier, plus sand filter or other recommended device.

It is assumed that the recommended tests will be performed using unmodified brine with no minimum limit on the temperature of the injection brine.

Brine modification for controlling scale is not covered by any proposed tests, since it would be time consuming and costly to modify the GLEF for this purpose. Investigations of modified brines have been actively pursued by the Lawrence Livermore Laboratory at the small four-stage flash system adjacent to the GLEF. This system should be modified to simulate the two-stage flash process, and the investigations should be continued under the Department of Energy. Industrial Support Program. To date, this work has indicated the two most promising brine modification methods: acidification or addition of other chemicals to prevent scale formation in equipment and piping and treatment to cause precipitation and removal of scale-forming species upstream of the power plant.

The testing of modified brine should be extended to the GLEF only after clear-cut and consistent results have been obtained from 
the small four-stage flash system. At that time, if brine modification is determined to be promising for use in commercial plants, the GLEF will need to be refurbished with materials capable of operating with brine of the selected $\mathrm{pH}$ at the targeted GLEF operating conditions.

Finally. it is assumed that the two-stage GIEF will have sufficient instrumentation to carry out the tests reliably and that all control systems will have been calibrated for their proper operation.

\section{1. 3 Operational Procedures}

Normal operation of the test facility and well field will be an ongoing requirement for the tests. Well shut-in tests will be conducted during a shutdown of the GLEF for maintenance purposes. It is essential to establish procedures for normal and emergency operations prior to commencing the tests. These procedures must give particular attention to the question of safety during emergency shutdown and upset conditions.

\subsection{Recommended Tests}

Tests for the power plant and the reservoir are interrelated. Hence, the overall test program must be carefully coordinated. Testing at the facility will take one of three forms:

- Where results have to be obtained from the ongoing process, e.g. scale formation. 
- Where results are dependent on work performed after an ongoing process, e.g.. scale analysis.

Where results can be obtained from a specific short term test on a component. e.g.. certain equipment performance.

Table 8-1 summarizes the tests in their order of priority and indicates the corresponding risk area from section 7.

Table 8-2 shows the proposed schedule for the recommended tests starting May 15, 1978. The schedule shows three distinct types of tests:

- Continuous, long term: shown as solid lines for the total duration of GLEF testing life (e.g.. tests associated with scale and corrosion)

- Continuous, short term; shown as solid lines for part of total duration of GLEF testing life (e.g.. steam cleaning)

- Intermittent, long term; shown as broken lines for the total duration of GLEF testing life (e.g... reservoir performance)

The schedule indicates that the tests will be completed by the end of 1978. However, it is expected that certain tests relating to some plant components, injection wells, production wells, and reservoir performance will be continued into 1979 in order to gather conclusive information that will be beneficial in making final design decisions during 1979. 
TABLE 8-1

RECOMMENDED TESTS FOR THE GLEF

\begin{tabular}{|c|c|c|c|c|}
\hline $\begin{array}{l}\text { Test } \\
\text { No. }\end{array}$ & Title & $\begin{array}{c}\text { Test } \\
\text { Priority }\end{array}$ & $\begin{array}{c}\text { Risk } \\
\text { Analysis } \\
\text { Priority }\end{array}$ & Risk Area \\
\hline 1 & Scaling in Plant & Al & 1 & 11 \\
\hline 2 & Plant Scale Removal Methods & A2 & 1 & 11 \\
\hline 3 & Corrosion and Erosion in Plant & A3 & 2 & 12 \\
\hline 4 & Reliability and Longevity of Plant Components & A4 & 3,4 & 17 and 18 \\
\hline 5 & Performance of Injection Wells & A5 & 5,6 & 21 and 25 \\
\hline 6 & Precipitation of Solids Prior to Injection & A6 & 7 & 24 \\
\hline 7 & Scaling and Corrosion of Injection well & A7 & 8,9 & 22 and 23 \\
\hline 8 & Performance of Production Wells & A8 & $10,11,23$ & 1,2 , and 7 \\
\hline 9 & Scaling and Corrosion of Production Well & A9 & 12,13 & 5 and 6 \\
\hline 10 & Brine Compatibility & Al0 & 14,18 & 8 and 27 \\
\hline 11 & Ground Subsidence & A11 & 15,16 & 10 and 26 \\
\hline 12 & Two-Phase Flows and Plant Stability & A 12 & 17 & 13 \\
\hline 13 & Noncondensible Gases & B1 & 19,20 & 3 and 15 \\
\hline 14 & Reservoir Performance & B2 & $21,22,23$ & $\begin{array}{l}1,2,4,7,9, \\
25, \text { and } 28\end{array}$ \\
\hline 15 & Steam cleaning & B3 & 26 & 14 \\
\hline
\end{tabular}


TABLE 8-2

SCHEDULE OF RECOMMENDED TESTS

FOR GEOTHERMAL LOOP EXPERIMENTAL FACILITY

\begin{tabular}{|c|c|c|c|c|c|c|c|c|c|c|}
\hline \multirow{2}{*}{$\begin{array}{l}\text { Test } \\
\text { No. }\end{array}$} & \multirow{2}{*}{ Title } & \multicolumn{8}{|c|}{ Year 1978} & \multirow{2}{*}{ Year 1979} \\
\hline & & May & June & July & Aug. & Sept. & Oct. & Nov. & Dec. & \\
\hline 1 & Scaling in Plant & & & & & & & & & \\
\hline 2 & Plant Scale Removal Methods & & & & & & & 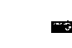 & 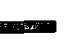 & \\
\hline 3 & Corrosion and Erosion in Plant & & & & & & & & & \\
\hline 4 & Reliablility and Longevity of Plant Components & & & & 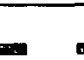 & & & & & 6 Months \\
\hline 5 & Performance of Injection Wells & & & & & & & & & 6 Months \\
\hline 6 & Precinitation of Solids Prior to Iniection & & & & & & & & & 6 Months \\
\hline 7 & Scaling and Corrosion of Injection Wells & & & & & & & & & \\
\hline 8 & Performance of Production Wells & & & & & & & & & \\
\hline 9 & Scaling and Corrision of Production Wells & & & & & & & & & \\
\hline 10 & Brine Compatibility & & & & & & & & & \\
\hline 11 & Ground Subsidence & & & & & & & & & \\
\hline 12 & Two Phase Flow and Plants Stability & & & & & & & & & \\
\hline 13 & Noncondensible Gases & & & & & . & & & & \\
\hline 14 & Reservoir Performance & & & & & & & & & 6 Months \\
\hline 15 & Steam Cleaning & & & & & & & & & \\
\hline
\end{tabular}


Test No. 1

SCALING IN PLANT

PRIORITY: A 1

RISK AREA: 11

OBJECTIVES

- To develop techniques for the measurement of scale thickness

- To determine the rate of scale formation at selected locations

- To establish the constraints placed upon the efficient and uninterrupted operation of the test facility by the formation of scale.

\section{SIGN IF ICANCE}

If scale deposition is not taken into account in the plant design, it will reduce the plant output with time because of reduced flow and increased pressure drop. Ultimately. scale can shut down the plant due to clogged flow lines, frozen pumps, plugged instrument lines, and inoperable valves. Any interruption of power production for cleaning would result in a serious loss of revenue. Scale formation increases costs due to added cleaning labor and materials and possibly equipment replacement. 


\section{Scale Thickness Measurement}

(a) Utilize available instruments and sampling methods for on-line scale detection. These include:

- Radiography. The disadvantages of this method are that there has to be a minimum scale thickness for detection and that safety precautions are required. The advantage is that the test equipment is portable.

- Thermography. This method is inexpensive, but has not been tried for this application.

- Surface contact Thermometers. The disadvantages are that the test is local with fixed equipment, that operator skill is required, and that electric contacts are subject to corrosion. The advantage is that it is inexpensive and easy to install.

- Ultrasonics. This techniques has been tried at the GLEF, but has not been successful to date.

- Removable Probes or Sample plates. These can be inserted and retrieved through mounts on the pipes or equipment without shutting down the test facility. This is a proven technique. The disadvantage is that the protuberances could attract scale.

(b) Provide rollout sections in the main stream that could be removed and inspected. A bypass at the rollout section would allow internal examination of the actual flow path without shutting down the test facility. The disadvantage is that there are only a few locations where this can be installed.

(c) Provide separate, smaller bore, parallel, side test streams. These would be alongside the main stream and could be isolated and opened up for examination without shutting down the main test facility. The disadvantages are that the test would be general in nature and may not reproduce actual conditions in the main stream. may not spot local scale, and would not give early scale warning. The advantage is that side test streams can be installed at any location in the test facility. 
Any procedure that requires the test facility to be shut down, for that activity alone, has been given a low priority. Thus, the opening up of lines or equipment for scale examination, except for rollout or bypass sections, should only be done when the test facility is shut down for other purposes. However, this examination is necessary for instrument calibration and scale confirmation.

\section{Scale Deposition Rate Measurement}

(a) Use computer models of chemical reactions and scale buildup rate in a simulated two-stage flash process. This has the advantage of being a generalized tool for the process, which can be used to compare separate or combined well chemical constituents. It is limited to sets of reactions that may not satisfy the actual conditions in the GLEF.

(b) Predict from tests reported in literature on synthetic brine solutions.

(c) Evaluate brine chemistry and scale buildup on samples in a field laboratory, using side stream brine flows from production wells. This has the advantage of being able to consider a large range of materials and brine conditions. However, it does not consider the configuration of a specific plant.

(d) Utilizing one or more of the on-line methods of scale thickness measurement, together with scale sample analysis, establish the effect of brine $\mathrm{pH}$. brine temperature, and mechanical forces (e.g.. turbulence) on the rate and type of scaling at various locations in the test facility.

\section{Scale Analysis}

scale samples can be obtained by on-line sampling techniques, from rollout or bypass sections, or when the test facility is 
shut down and opened up. Scale constituents may be identified by standard laboratory technology.

\section{Scale Effect on Plant Performance}

This will be an ongoing test for the duration of the 1978 test period without any alternative procedures. Records should be kept of all malfunctions and interruptions of the test facility operation, and performance degradation caused, directly or indirectly, by the presence of scale should be monitored. The records should include scale thickness at the time of failure or shutdown for cleaning, together with its type and rate of deposition.

RECOMMENDED PROCEDURES

The recommended procedure to measure scale thickness is to review available commercial instrumentation; other test facility techniques, and GLEF experience. Then to install the best of the immediately available methods that can be used without interruption of the test facility operation.

The selected techniques would be used at specific locations in the test facility to detect the presence of scale and to record the rate of scale deposition over time.

Scale analysis would be carried out by a laboratory, which for continuity should be available for the entire test period. Scale 
samples would be obtained by on-line sampling, rollout, and sidestream methods and when the test facility is shut down.

All malfunctions and interruptions of the test facility operation caused, directly or indirectly, by the presence of scale would be monitored together with the test facility state point conditions and brine analysis. The monitoring and analysis would occur throughout the test period.

The test should determine factors affecting location of scale, scaling rates, type and hardness of: scale, and the effect of line velocities on scale and scale buildup. The results will be used in determining economic cleaning procedures. In addition, the information can be used in designing the 50 MWe power plant, e.g., in determining pipe diameters and flow velocities.

Initial cost will be entailed in obtaining the scale detection equipment and its installation. subsequent costs will be incurred in monitoring, sampling, and laboratory analyzing as well as in any changing of the instruments and their location. The total cost for this test will be moderate. 
Test No. 2

PLANT SCALE REMOVAL METHODS

PRIORI TY: $\quad$ A2

RISK AREA: 11

OBJ ECT IVES

- To test mechanical, hydraulic, and chemical descaling procedures

- To develop a criterion for the frequency of scale removal on the basis of plant operability and economics.

\section{SIGNIFICANCE}

This test, together with Test No. 1, will serve to establish the economic significance of scaling and its removal. In a commercial power plant, scale buildup and removal can be expensive not only because of cleaning but also because of the loss in revenue when the plant is shut down. The effects can conceivably be minimized by a regular cleaning program with some of the descaling shutdowns coinciding with scheduled shutdowns for other plant maintenance.

\section{ALTERNATIVE PROCEDURES}

(a) Use plastic pigs of different hardnesses or articulated pigs for removing the scale in pipes. The advantages are that it is easy to run a pig in the pipe without disassembling the installed pipe. it is simple to operate, and it is inexpensive. The disadvantages are that the use of pigs is restricted to pipes only and not suitable for cleaning other equipment such as flash vessels. pumps, etc. 
(b) Use cavitation principle to remove the scale. The advantages, such as ease of operation, economy. etc. are yet to be proven for long-term applications. The disadvantage is that it is completely unproven for removing the hard scale encountered in the salton sea brine.

(c) Use hydroblasting to remove the scale. The advantages are that it is effective for large areas with easy access, it is simple to operate, and it is fairly inexpensive. However, it does have major disadvantages. Its application is restricted to large areas only and is not suitable for small diameter pipes, and it cannot be used while the plant is in operation.

(d) Use suitable chemicals to dissolve the scale. It is easy to apply. Items not easily accessible to other methods can easily be subjected to chemical soak, e.g., small diameter pipes, vessel drains. valves, pumps, etc. The disadvantages are that it is expensive if used for pipes, vessels, etc.. and it cannot be used while the plant is in operation.

(e) Use manual cleaning. This is suitable for items such as valves, pumps, etc. with or without chemical soaking. There are no significant advantages to this method. The disadvantages are that it is time consuming, it is very costly, and it requires plant shutdown when sufficient redundancy is not provided.

(f) Use thermal shock. The advantages are that it can be applied on-line, it is not time consuming, and it is inexpensive. The disadvantages are that it consumes a lot of thermal energy, component life will be reduced due to thermal cycling, it is very difficult to impose thermal shock on large components that are physically connected to a large source or sink. small components can be subjected to thermal shock only if they are isolated or dismantled from the system, and to design the whole brine system suitable for thermal shock will be time consuming and very costly in such areas as pipe hangers, steel supports, etc.

(g) Use vibration to dislodge the scale. The advantages are that it is not time consuming. it is reasonably quick, and it can be applied on line. The disadvantages are that the components will be subjected to cyclic stresses thus reducing their life, it will consume a large amount of energy especially for heavy components, and designing the whole brine system suitable for on-line: vibrations 
will involve sophisticated engineering and hence will be costly.

(h) Use externally driven scrapers. The advantages are that it is quick and easy to operate on short length pipes and is relatively inexpensive. The disadvantages are that it is unsuitable: for long pipe runs unless the run is divided into a series of short pipes with access, and it is not suitable for equipment such as tanks, vessels, valves, pumps, etc.

RECOMMENDED PROCEDURE

The recommended procedure for scale removal is, in conjunction with TEst No. 1, to first monitor scale buildup at various locations in the test facility. When the scale becomes critical to the continuous operation of the test facility, the plant should be shut down and cleaned. The recommended cleaning procedure is a combination of the alternative procedures. For pipes, use both solid and articulated pigs with and without chemicals to arrive at the most cost effective method. For vessel walls, etc., where accessibility is not a problem, use hydroblasting with and without chemicals. Use chemicals for small diameter pipe, drains, etc. Manually clean the scale from valves, pumps, etc. with and without chemicals. The test should be run continuously at GLEF using the recommended methods until all the necessary data are collected. The data should be used to develop an optimum criterion for removing scale.

After each cleaning session, measure and record the wall thickness of pipes, vessels, etc. as a means of monitoring the 
effect of scale removal methods and short-term corrosion of the parent material prior to the deposition of protective scale.

With two parallel flash vessel trains, it is possible to demonstrate the cleaning of one train without shutting down the entire plant.

This will be a periodic test throughout the duration of the 1978 test period. cleaning will be an operational cost, but it is essential as scale deposition is a high risk area. However, the costs and cleaning time should be reduced as more efficient methods and procedures are developed. Also, it may be more economical to clean more frequently and use a shorter outage period for cleaning. The total cost for this test will be moderate. 
Test No. 3

CORROSION AND EROSION IN PLANT

PRIORITY: $\mathrm{A} 3$

RISK AREA: 12

OBJ ECT IVES

- To develop techniques for the detection and measurement of corrosion and erosion

- To determine the rates of corrosion and erosion

- To ascertain the types of corrosion

- To study the effect of corrosion and erosion on the performance of the test facility and on components in the facility

\section{SIGNIF ICANCE}

Based on data from the GLEF, corrosion and erosion may be a secondary risk area when related to the scale risk. However, if the scale problem were reduced, corrosion and erosion problems may increase. In addition, corrosion is time dependent, and present GLEF tests may not have been of long enough duration to evaluate its long-term effect. Thus, the life of the plant is directly related to the rate of corrosion and erosion. Excessive downtime of the plant due to the development of corrosion or erosion and repairs or replacement of failed plant components can be costly. An undetected corrosion point constitutes a hazard to plant operators. 


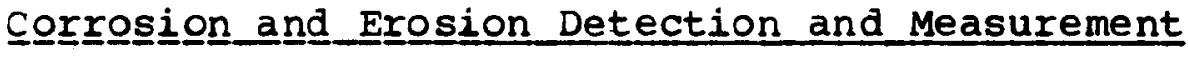

Visual examination of the system internals.and the cutting and processing of test specimens require the shutting down of the test facility. This is time consuming and expensive. Thus, online test procedures are desirable.

(a) Utilize the application of commercial instruments for on-line corrosion and erosion detection. These include, but are not limited to,

- Ultrasonics. This technique is known to be effective but requires skill in operation and interpretation of results. The advantage is that the test equipment is portable.

- Radiography. This technique is known to be effective. The disadvantage of this method is that safety precautions are required. The advantage is that the test equipment is portable and can test any part of a pipe or equipment.

- Eddy Currents. This technique is successfully used to measure metallic and non-metallic coatings on metals and would have the advantage of allowing automatic testing at any point in the system. It has not been tried at the GLEF but is used in industry.

- Corrosion Rate probes. The disadvantage of this technique is that the test is local with fixed equipment and requires installation. The advantage is that continuous test data are obtained.

- Cumulative Damage Probes. The disadvantage of this technique is that the test is local with fixed equipment and requires installation. The advantages are that the method has been used and continuous test data are obtained.

(b) Use corrosion test coupons or erosion wear plates. with suitable mounting bodies on the lines and 
equipment and on-1ine retrievers. The coupons and plates can be inserted and removed without shutting down the test facility. This technique has been proven, and it is flexible. Location can be readily changed since new mounting bodies can be installed without shutting down the test facility.

(c) Provide rollout sections in the main stream of the test facility that can be removed and inspected. A bypass at the rollout section would allow the examination without shutting down the test facility. The locations where this section could be installed are limited.

(a) Provide separate, small bore, parallel side test streams. These would be alongside the main stream and could be isolated and opened for examination without shutting down the main test facility. The disadvantage is that the test facility would have to be modified for each test stream, which would be an added expense.

opening up lines or equipment is not an on-line procedure but is desirable to confirm the other procedures and to calibrate any instruments. The disadvantages are that the test facility has to be shutdown. Also, the cost of cutting and welding openings is expensive, the corrosion may not be at the suspected area, which leads to making further openings, and no early warning is given. The advantage is that when corrosion is found, positive measurements can be made and no uncertainty exists. 
Rate of Corrosion and Erosion Measurement

(a) Simulate in a laboratory at the GLEF the conditions at various locations in the proposed 50 MWe power plant. Insert and study corrosion test coupons. which can be installed in suitably designed test sections. Record and analyze the results for corrosion rates in a data acquisition system. This procedure is flexible as it can be easily changed and coupons can be easily inserted and retrieved. The disadvantage is that it does not cover full scale conditions for pipes and equipment.

(b) By methods selected for corrosion and erosion detection measurement, together with data on the test facility operation, establish the rate of corrosion or erosion in various locations in the brine and steam systems in the test facility.

\section{Type of Corrosion or Erosion}

After corrosion has been detected and its rate of formation established, it is necessary to ascertain whether it is a uniform or non-uniform type. This can be determined by metallurgical examination from either test coupons, if they have been used, or if the data are from instrument analysis, it has to be corroborated by a review of the surface when the GLEF is opened. The results will be evaluated and related to the effect of brine temperature. $\mathrm{pH}$, pressure, composition, mechanical forces, materials, the presence of noncondensible gases or air, and the test facility layout.

\section{Effect of corrosion and Erosion on Plant Performance}

This will be an ongoing test for the duration of the 1978 test period without any alternative procedures. Records will be kept of all malfunctions and interruptions of the test facility related, directly or indirectly, to corrosion and erosion 
RECOMMENDED PROCEDURE

The recommended procedure in assessing the effect of corrosion and erosion in the plant would be to first establish the best immediately available techniques for measuring corrosion or erosion.

The selected techniques would then be used at specific locations in the test facility to detect the presence of corrosion or erosion and then to monitor the rate of corrosion and erosion. This would take place without interruption to the operation of the test facility.

Whenever the test facility is shut down for other reasons or if justified to obtain the information, the specific locations should be opened, inspected visually, and, if necessary, test specimens of the corrosion or erosion should be taken. These test specimens would be examined by a metallurgical laboratory to corroborate the type of material attack.

Records should be kept of all malfunctions and interruptions of the test facility operation related, either directly or indirectly, to corrosion or erosion, noting the nature of the attack, its location, and depth and composition of the corrosion products to the extent that such information can be determined.

The monitoring and analysis would occur throughout for the entire 1978 test period. 
Initial costs will be incurred in obtaining the corrosion detection equipment and its installation. Subsequent costs will be for monitoring, metallurgical analysis, and plant analysis, as well as for any changes to the instruments and to their location. Thus, the total costs for this test will be moderate.

In addition, corrosion and erosion studies should be continued under the Department of Energy. Industrial support Program, in the small four-stage flash test system setup adjacent to the GLEF. This system should be modified to simulate the two-stage flash process. Tests using coupons for material evaluation are of greatest value. 
Test No. 4

RELIABIIITY AND IONGEVITY OF PLANT COMPONENTS

PRIORITY : A4

RISK AREA: 17 and 18

OBJ ECT IVE

- To select and test pumps, valves, controls, and instruments capable of operating dependably and for long periods in the GLEF environment

\section{SIGN IF ICANCE}

Failure of minor plant components may entail a substantial loss of plant availability and costly repairs or replacement. Even though operation may continue in spite of defective items (e.g., a frozen control valve) , plant performance will not be optimum. Inoperable controls can result in instability or severe oscillations in plant systems that can be significantly detrimental to plant availability.

\section{ALTERNATIVE PROCEDURES}

(a) Assess on a continuous basis the functioning of the critical GIEF items. Keep an accurate record of all failures, type of corrective measure, cost of repairs (or replacement) in manhours and materials, and loss of plant availability.

(b) Review and improve operating procedures based on ongoing GLEF operational experience.

(c) select from previous GLEF experience promising alternative components; install and test in modified GLEF.

(d) Contract with the component manufacturers to develop and test pumps, valves, controls, and instrumentation suitable for use in the GLEF environment. 
(e) Provide a rollout section in the main stream as a test bed for instrument development. A bypass at the rollout section would allow the test bed to be removed and internally inspected without shutting down the test facility.

RECOMMENDED PROCEDURE

The recommended procedure would be a combination of all the alternatives. Emphasis should be put on surveying the most critical components and getting the manufacturers to develop improvements.

This test would be ongoing but not continuous for the duration of the 1978 test period and should continue into 1979 when the design criteria will be defined for component design. The costs would be moderate to expensive and would involve the recording and analysis of plant performance, meetings with manufacturers, and the purchasing and testing of improved items. 
Test No. 5

PERFORMANCE OF INJECTION WELLS

PRIORITY: A5 RISK AREA: 21 and 25

OBJ ECT IVE

- To establish the capacity of existing and future injection wells to accept brine as a function of wellhead pressure

SIGNIFICANCE

Permeability of the formation may not allow full design flow conditions. Malfunction of the injection wells will result in high injection pressures and the increased consumption of pumping power. cleaning costs may become substantial. Wells may have to be abandoned and new injection wells drilled; this would be a costly process.

\section{ALTERNATIVE PROCEDURES}

(a) Use calculations to determine the fluid flow and thermal-front movements from the injection wells. These could involve either semi-analytical or numerical modeling. The advantage is that this procedure can be carried out on any theoretical well array. The disadvantage is that the results are dependent on the input data and theory used.

(b) Continue to run and record data on the existing wells. The main measurements being flow rates. injection brine chemistry at the wellhead, and downhole pressure and temperature.

(c) Survey the existing wells using more sophisticated data gathering equipment to improve the present extrapolation of existing data. Type of equipment would be electrical tools, radioactive tools, and acoustic tools. 
(d) Survey the existing wells and determine the well with the poorest rate of brine acceptance. Apply well rework and cleanup procedures, then recommence brine injection, and measure temperature, well flow, and wellhead pressure for changes.

(e) If procedure (d) shows no change, block off well at selected level so that injection will be to a different strata. Obtain new data for flow. temperature, and pressure.

(f) Drill an injection well in a new area, ensure core samples are taken, and improve logging and testing techniques.

\section{RECOMMENDED PROCEDURE}

The recommended procedure is to utilize the procedures from (b) to (f) in a progressive sequence. Each subsequent stage would depend on previous results obtained, time remaining, and additional costs. In addition the permeability of the wells may be affected by procedures from other tests. For example. Test No. 6 could lead to a reduction in scaling in the wells.

This is a high risk item, with the unknowns continuing with each new injection well. Thus, it is essential to have as much information about each existing well, as accurate as possible. The cost of new instrumentation and operator time to investigate each well would be the main cost. The cost and time schedule may not permit the drilling of a new well or even altering an existing well. Thus, the basic costs will be moderate, however reworking existing wells will be expensive, and the drilling of a new WEII will be very expensive. 
The test would be ongoing throughout the 1978 test period, though the investigations and reviews will be periodic. Based on GLEF operational data where wells have had a rapid flow reduction after 9 months, monitoring of the brine injection conditions should be continued after the end of the 1978 test period to enable the test run to be continuous at full flow for 9 to 12 months.

Imperial Magma and Lawrence Iivermore Laboratory have conducted test programs in this risk area. Their test data should be reviewed. Further work, supported by the Department of Energy. Industrial support Program and Imperial Magma is needed and should be coordinated with the overall program. 
Test No. 6

PRECI PITATION OF SOLIDS PRIOR TO INJECTION

PRIORITY : A6

RISK AREA: 24

OBJ ECT IVES

- To reduce scale buildup in the discharge lines from the test facility to the injection well

- To extend the well life by reducing the quantity of suspended solids that might deposit in the well casing or clog the casing slots

- To avoid appreciably reducing the permeability of the receiving reservoir

\section{SIGN IF ICANCE}

Continual cleaning of the discharge line will be a costly and time consuming requirement. Precipitations in the well will be difficult to remove and will require the well to be shut down for cleaning: severe cases of scaling may need redrilling of the well or even abandonment. Reduced permeability of the reservoir also could lead to the abandonment of the well.

\section{ALTERNATIVE PROCEDURES}

(a) Rely entirely on existing information. This would lead to reduced output either from reduced flow or increased pumping power requirements. Ultimately. the procedure could be expensive due to cleaning or the need for new substitute wells.

(b) Install settling ponds or tanks. The disadvantage, especially for a 50 MWe power plant is the area required. Settling ponds also require careful liner or subsoil design to prevent leakage into the water table. The advantage is that holding time and any additives required to settle suspended 
matter can be varied, depending on the brine effluent chemistry.

(c) Add a reactor clarifier, which uses flocculents and requires no $\mathrm{pH}$ adjustment. This is a large item of equipment that requires operator attention. The advantage is that initial GLEF tests have given promising results.

(d) Use test filters, multimedia sand, or diatomite followed by polishing filter. These would be used in conjunction with other procedures.

(e) Inject noncondensible gases. The disadvantage is that the gas compression costs are excessive. However, it is one method of disposing of noncondensible gases. Also, the noncondensible gases reduce the $\mathrm{pH}$ of the brine, thus providing scale control, another problem area.

(f) Use hydrocyclones. The advantage of this method is that it is used in industry and units are commercially available.

(g) Require only partial cleanup, using smaller and therefore less costly equipment than itemized in (b) to (f).

\section{RECOMMENDED PROCEDURE}

The recommended test procedure is to continue the present site evaluation of alternatives (b). (c), and (d). The equipment should be capable of taking full flow well flows and should consist of either settling tanks or a reactor clarifier plus filters. These tests would be ongoing and continuous for the whole of the 1978 test period and at least 6 months of 1979. This is one of the most serious risk areas, therefore the very expensive cost of obtaining major items of equipment and testing the best alternatives would be justified. 
In addition, the small scale test investigations on brine handling and scale control methods should be continued under the Department of Energy, Industrial Support Program. 
Test No. 7

SCALING AND CORROSION OF INJECTION WELL

PRIORITY: A7

RISK AREA: 22 and 23

OBJ ECT IVES

- To determine the corrosion and scaling rate of injection well casing

- To select suitable materials of construction

\begin{abstract}
SIGNIFICANCE
Corrosion and scaling of the well casing may require costly repairs or, at worst, abandonment of the well. The selection of material that does not give a long operating life will require repairs or replacement.
\end{abstract}

\title{
ALT ERNATIVE PROCEDURES
}

(a) Install test coupons of various materials in the line just before the injection wellhead. The advantages are that it is inexpensive, least time consuming, and a large number of materials can be tested. The disadvantages are that flow pattern around the coupons is not similar to that in the infection well. localized erosion may result that can be misinterpreted as corrosion, without proper electrical isolation between coupons, cathodic corrosion may result, and the coupons can be installed and inspected only when the plant is down.

(b) Install test pipe spools of selected materials in a line paralled to the injection line. The advantages are that a selected number of materials can be tested, brine-casing wall interaction will be : realistic, and modifications and test measurements can be made while the plant is oper- 
ating. The disadvantages are that the modification and installations are expensive, major modification to the injection system piping are required while the plant is down, and corrosion and scaling are monitored in the injection line and not in the well casing.

(c) Install removable strings (sleeves) of selected materials in the injection well. The advantages are that a selected number of materials can be tested, brine-casing wall interaction will be most realistic, and measurements for scale and corrosion are taken downhole. The disadvantages are that it will be expensive, will take several days to install the the tubes in the well, and will require periodic shutdown of the well to pull the strings for inspection. The plant can continue to run if a standby injection well is available.

(d) Apply the methods selected under Tests No. 1 and No. 3 for on-line measurement in the line ahead of the injection wellhead. The advantages are that it is inexpensive, it is reliable, regular measurements can be taken while the plant is in operation, continuous monitoring to establish the rates is possible, and actual measurements on the injection line can be taken for verification during regular shutdown of the plant. The disadvantage is that the measurements are taken in the injection line and not in the well.

(e) Use calipers to measure the diameter at various depths of the injection well. The advantages are that the brine-casing wall interaction is exact, no additional time is required since the test can be done during scheduled shutdowns, and it is inexpensive. The disadvantages are that the well flow needs to be stopped and a standby injection well is needed for uninterrupted operation of the plant, and absence of scale deposits at the point of measurement cannot be verified because no visual inspection is possible and differentiation cannot be made between scale and corrosion.

(f) Use magnetic induction and conventional oil well logging techniques. The advantages are that the metallic well-casing wall measurement is exact; no additional time is required because the test can be done during scheduled downtime, it is inexpensive. and instruments are available to assess the corrosion on the outside of the wall casing. The disadvantages are that the well flow needs to be stopped while a standby injection well is used for uninterrupted operation of the plant, the method is limited by well diameter and the temperature at the 
measuring point, the methods cannot estimate the combination of scale and corrosion at the same location, and the thickness of nonmagnetic scale may adversely affect the reading.

\section{RECOMMENDED PROCEDURE}

Alternative (d) using on-line measurement is recommended. The measurements should be verified by using alternatives (e), caliper measurements of well casing, and (f), magnetic induction measurements of well casing, when the well is shut down. Recommended methods would be time consuming and moderately expensive, but it is essential to establish the scaling and corrosion of the injection well so that the associated risks can be minimized. The recommended procedure for material selection is alternative (c), with the installation of removable strings of selected materials in the injection well. The tests would be continous for the duration of the 1978 test program. However. this test should be considered for continuation into 1979 in order to extend the data gathering period. This is essential for long-term corrosion measurements. 
Test No. 8

PERFORMANCE OF PRODUCTION WELLS

PRIORI TY: A8

RISK AREA: 1, 2, and 7

OBJ ECT IVES

- To establish the characteristics of the production wells, that is, the rate of production for given bottom-hole pressure and temperature, wellhead pressure, well depth, and layout and formation permeability

- To predict the trend of well performance, particularly temperature and flow decline with time

\section{SIGNIFICANCE}

It is necessary to have assurance that the well field for the 50 MWe demonstration power plant can produce at an adequate rate and with an acceptable quality over the anticipated 30-year life. Also, knowledge of temperature and flow decline is necessary to determine additional well requirements and plant component design and hence to assess the 30-year well field and plant investment required.

\section{ALTERNATIVE PROCEDURES}

(a) Apply a theoretical approach to the well field surrounding the test facility, fitting data of flow decay. temperature decline, and thermal transients from existing well fields with proven case histories. The disadvantage of this procedure is that the results are dependent on the input data which may not fit the salton sea geothermal wellfield conditions. Also, assumptions will have to be made that will be general in nature.

(b) Simulate, on computer models, well conditions including scale deposition. This procedure is 
dependent on geological and geophysical input data. empirical correlations, and assumptions for unknowns.

(c) Continue to update and correlate data from all existing wells in the area surrounding the test facility. This could include wells not operated by GLEF. This has the advantage of continuing ongoing tests but is limited to a few wells that may not be typical of the area and may not have operated for a long enough time to establish declines.

(d) Charge depth of at least one well and obtain new data. This has the advantage of extending information on strata level and its relation to well flow.

(e) Drill new well, or wells, and obtain new data. The disadvantages are the cost and time required to obtain the data. The advantage is that the well location can be chosen with reference to known data to obtain better representative wells.

\section{RECOMMENDED PROCEDURE}

The recommended procedure is to obtain additional or extended data from all wells in the area, alternative (c), and to use models, alternative (b) . to extrapolate this information. The main information required for each well is its production rate, thermodynamic characteristics, and chemical composition. This would be an ongoing test, carried out over the duration of the 1978 test period. However, if the production wells continue to operate after the end of the year, data gathering should continue. For the GLEF wells, the costs will depend on the additional instrumentation required, the recording and monitoring of the data, and the subsequent analysis. In addition, costs will include modeling and testing wells not at the GLEF. Thus, the basic costs will be moderate, however, reworking existing 
wells will be expensive and the drilling of a new well will be very expensive.

Within the time span of the proposed tests, it would be difficult to drill, and have in production, more than one new well. However, it is recommended that during the drilling of wells for the 50 Mwe demonstration power plant an overall, ongoing test program would be planned and coordinated. This would include core samples for each new well. 
Test No. 9

SCALING AND CORROSION OF PRODUCTION WELL

PRIORITY: A9

RISK AREA: 5 and 6

OBJ ECT IVES

- To determine the corrosion and scaling rate of the production well casing, wellhead equipment, and production line to the plant

- To determine suitable materials of construction

\section{S IGN IF ICANCE}

Corrosion and scaling may require costly repairs or cleaning of the well field components or, at worst, early abandonment of the we 11.

\section{ALTERNATIVE PROCEDURES}

(a) Install test coupons of various materials in the lines just after the production wellheads. The advantages are that it is inexpensive, least time consuming, and a large number of materials can be tested. The disadvantages are that the flow pattern around the coupon is not similar to that in the production well, localized erosion may result, which can be misinterpreted as corrosion, without proper electrical isolation between the coupons. cathodic corrosion may result, and coupons can be installed and inspected only when the plant is shut down.

(b) Install test pipe spools of selected materials in a line parallel to the production lines. The advantages are that a selected number of materials can be tested, brine-casing wall interaction will be realistic, and modifications and test measurements can be made while the plant is operating. The disadvantages are that the modifications and installation are expensive, major modification to the production system piping are required while the plant is down, and corrosion and 
scaling are monitored in the production line and not in the well casings.

(c) Install removable strings (sleeves) of selected materials in the production well casings. The advantages are that a selected number of materials can be tested, brine casing wall interaction will be most realistic; and measurements for scale and corrosion are taken downhole. The disadvantages are that it will be expensive, it will take several days to install the tubes in the well, and will require periodic shutdown of the well to pull the strings for inspection. The plant can continue to run if another production well is available.

(d) Apply the method selected under Tests No. 1 and No. 3 for on-line measurement in the lines after the production wellheads. The advantages are that it is inexpensive, it is reliable, regular measurement can be taken while the plant is in operation: continuous monitoring to establish the rate is possible, and actual measurements on the production lines can be taken for verification during regular downtime of the plant. The disadvantage is that the measurements are taken in the production lines and not in the well.

(e) Use calipers to measure the diameter at various depths of the production wells. The advantages are that the brine-casing wall interaction is exact and it is inexpensive. The disadvantages are that the well flow needs, to be stopped and a standby production well is needed for the uninterrupted operation of the plant, stopping and restarting the well will take several days, and absence of scale deposits at the point of measurement cannot be verified because no visual inspection is possible and differentiation cannot be made between scale and corrosion.

(f) Use magnetic induction and conventional oil well logging techniques. The advantages are that the metallic well casing wall measurement is exact, no additional time is required because the test can be done during scheduled downtime, and it is not expensive. The disadvantages are that the well flow needs to be stopped while a standby production well is utilized for uninterrupted operation of the plant, the instruments are limited in their use by the well diameter and temperature at the measuring point, the method cannot estimate the combination of scale and corrosion at the same location, and the thickness of nonmagnetic scale may adversely effect the reading. 


\section{RECOMMENDED PROCEDURE}

Alternative (d) using on-line measuring devices is recommended. The measurements would be verified during scheduled plant shutdowns using alternative (e). caliper measurements of well casings and alternative (f), magnetic induction measurements of well casing. These procedures will be time consuming and moderately expensive, however, it is essential to gather all the necessary data with regard to scaling and corrosion of production wells so that the associated risk can be minimized. The recommended procedure for material selection is alternative (c). with the installation of removable strings of selected materials in the production wells. This will be an ongoing test for the whole of the 1978 test period. As more information becomes available over a large time span, the accuracy of the estimate of production well scaling and corrosion over 30-year life will be improved. 
Test No. 10

BRINE COMPATIBIIITY

PRIORITY: A10

RISK AREA: 8 and 27

OBJECTI VE

- To establish the compatibility of fluids from different wells

\section{SIGN IF ICANCE}

For the process to be chemically stable, and trouble-free over a 30-year life, it is essential to establish that the fluids from different wells will be compatible with or without additives.

\section{ALTERNATIVE PROCEDURES}

(a) Obtain samples from a number of wells and analyze them in the laboratory at the GIEF si te for their composition. On this basis, theoretically predict their compatibility. The advantages are that it is quick and it is least expensive. The disadvantages are that it is theoretical, it is only as accurate as the sample analyses, and it is very approximate, since the approach does not take into consideration the brine flow through the plant with resulting change in pressure, temperature, composition, and concentration.

(b) Obtain samples from a number of wells and analyze them. Mix these samples in differing proportions in the laboratory and study the mixture for compatibility. The advantages are that it is relatively inexpensive, it is reasonably quick, and the behavior of the mixture, while it is flowing through the plant with changes in pressure, temperature, composition, and concentration, can be predicted. The disadvantages are that the mixing is done at a temperature which is different from the production well outlet temperature, the behaviors of mixutre in the plant cannot be studied but only predicted with certain qualifications, and the effect of mixing small quantities of brine is 
assumed to be the same as mixing large quantities of brine.

(c) Mix full flows from various wells at the site and investigate their compatibility as the mixture flows through the plant. The advantages are that it is the most realistic method and very accurate and the results can be used, without qualification. directly for the future design of the 50 MWe plant. The disadvantages are that it is expensive, it is time consuming, and results are only as good as the representative number of wells used for the test.

\section{RECOMMENDED PROCEDURE}

Alternatives (b) and (c) are recommended. If the fluids are found to be incompatible at a later date during the operation of the power plant, the resulting consequences may force severe alterations in equipment and operation, costing millions of dollars and possibly abandoning the power plant. This risk will have to be minimized, and, hence, the very moderate expense and time involved in gathering the information for the study of compatibility of fluid is completely justified. This test will be performed together with Tests No. 13 and No 14 . 
Test No. 11

GROUND SUBSIDENCE

PRIORITY: A11

RISK AREA: 10 and 26

OBJECTI VES

- For the area of GLEF reservoir, to monitor for ground subsidence that may result from production and injection of the brine

- To predict the effect of brine production and injection for the proposed power plant

\section{SIGNIFI CANCE}

subsidence produces undesirable environmental and economic consequences. Additional expenses will be incurred to minimize subsidence. Since subsidence will not be permitted in the Imperial valley, infection flow may have to balance production flow, which will require the purchase and transmission of makeup water from an external source. Additionally, treatment of such water may be costly, depending on its chemical composition.

\section{ALTERNATIVE PROCEDURES}

(a) Based on the work done to date at GLEF, other salton sea KGRA data outside GLEF, and reported occurrences of subsidence at known geothermal fields, predict the probability of subsidence in the salton sea KGRA with the aid of computer modeling. The advantages are that it is inexpensive, less time consuming, and flexible. The disadvantages are that the results thus obtained are only approximate and it does not significantly contribute to the prediction of occurrence of subsidence.

(b) Accumulate data on geological structure of the substrata encompassing the production and infection 
wells, by way of core samples, seismic tests, etc. Build a computer model and simulate production with 100 percent injection and less than 100 percent injection, respectively. The advantages are that it is flexible and should yield reasonably acceptable results. The disadvantages are that it is expensive and time consuming.

\section{RECOMMENDED PROCEDURE}

Alternative (b) is recommended. This test will be done in conjection with Test No. 14, Reservoir Performance. An Imperial Valley Subsidence Detection Network is already in existence under the supervision of California Division of $O i l$ and Gas, and a program has been set up establishing a local subsidence detection network in the vicinity of the GLEF. This work under the Department of Energy, Industrial support Program, should continue. This will ensure that a complete case history is available to establish the degree of subsidence due to geothermal activities as opposed to natural subsidence. In addition, the Lawrence Berkeley Laboratory has a Geothermal Subsidence Research Program to understand and control subsidence assocated with geothermal energy development. Reports from this program should be reviewed, especially for guidelines regarding the siting of future production, injection, and observation wells and their operation. The cost and time for this test will be moderate. 
Test No. 12

TWO-PHASE FLOW AND PLANT STABILITY

PRIORI TY: A12

RISK AREA: 13

OBJECTI VES

- To determine the effect of two-phase flow on plant stability, pressure drop, data observations, and operational control

- To solve problems associated with instability

\section{SIGNIFICANCE}

Two-phase flow can have a profound effect on plant stability and control. Unstable performance, producing sharp surges in the pressure and flow rate of steam from the flash vessels, may shorten the life of the turbine. In the absence of reliable design data for two-phase flow, it may be necessary to use wellhead separators and separate piping for steam and brine. This arrangement will definitely increase the capital cost considerably.

\section{ALTERNATIVE PROCEDURES}

(a) Rely on published experimental results and their correlation with theoretical works for design of a brine system. The advantages are that it is the least expensive, reasonably quick, and no further work is needed at GLEF. The disadvantages are that it is not applicable directly for the salton sea KGRA brine, the experimental efforts are for a particular configuration of piping, not enough data exist for predicting plant operational stability. control system response, etc. and insufficient data exist in the area of fluctuating production well flow. 
(b) Conduct a series of tests in the laboratory on a bench scale configuration with two-phase flow. Also simulate the fluctuations in the flow. The advantages are that it is not costly, the test can be done elsewhere without interferrring with the normal operation of the GIEF, it is reasonably quick since it is not dependent on the modification of the GIEF, and the results obtained should have a reasonably good accuracy. The disadvantages are that the work will not be for Salton sea KGRA brine, some accuracy may be lost while applying these results to the full scale plant, random fluctuations of the production well flow cannot be duplicated in the laboratory, and the interacting effects of various systems such as the turbine generator, brine system, steam system, cooling water system. etc.. cannot be reproduced realistically in the laboratory.

(c) Establish a computer model of the projected 50 MWe power plant and study the effect of fluctuating brine flow from wells on various systems such as turbine-generator, brine system, steam system, and cooling water system. The advantages are that it is flexible, without installing a turbine-generator its theoretical response can be studied, and work can be done without interfering with the GLEF tests. The disadvantages are that it is purely analytical, the conclusions will have to be substantiated by test work, and it is time consuming.

(d) For two well flows, conduct two-phase flow tests by measuring pressure, temperature, flow, and dissolved solids at well head, first stage, and second stage. Establish a criterion for pressure drops through the system. Study the fluctuation in pressure as the brine flows from well head to the plant and through the plant. Flow and velocity measurements will establish the effect of brine quality on pressure drop and instrument response. Tests should be conducted on the efficiency of surge suppressors of various designs and different control systems in damping line oscillations. The response of the plant to the control system should be noted during periods of steady brine flow and during oscillations in the feed line. The advantages are that the results obtained are realistic and directly applicable to the 50 MWe (net) power plant design and the required design criteria for two-phase flow and surge suppressors can be easily developed. The disadvantages are that it is expensive and time consuming. 
(e) Flow test a spare well with well head separator. Test for stability of the separated fluids by measuring flow and pressure at the exits of the separator. The advantages are that it is not expensive and it can be run without interfering with GLEF tests. The disadvantages are that the brine flow through the plant cannot be studied and control system behavior due to the effects of twophase flow in the plant cannot be studied.

\section{RECOMMENDED PROCEDURE}

Alternatives (d) and (e) are recommended. The moderate time and expense involved with these alternatives are justified because no adequate guide for designing for two-phase flow exists, little is known about the effect of fluctuating brine flow on control system and turbine generator performance, the acceptable level of fluctuation of the brine flow for a power plant is not known and criteria for defining optimum configuration of two-phase brine flow piping and pipe supports are not known: design information for surge suppressors is not well defined. 
NONCONDENS IBLE GASES

PRIORITY : B1

OBJ ECT IVE

- To determine the quantity of noncondensible gases contained in the brine

- To analyze the gas for its components

- To determine the level of hydrogen sulfide in the ambient air

\section{SIGNIFICANCE}

A high content of noncondensible gases has a detrimental effect on turbine efficiency. Design factors, associated with plant design to allow for the noncondensible gases, will affect capital costs. In addition, the hydrogen sulfide content of the gases vented from the power plant is anticipated to be environmentally objectionable. Hydrogen sulfide abatement equipment selection will influence plant capital cost and operation.

\section{ALTERNATIVE PROCEDURES}

(a) Rely on the existing literature and data obtained to date from GLEF experiments. Assume a realistic change in the amount of noncondensible gas in brine such that a reasonable margin of safety can be allowed for design purposes. The advantages are that it is the least expensive alternative and the least time consuming. The disadvantages are that it is only approximate, it cannot be applied to the whole reservoir, and the long-term prediction of hydrogen sulfide concentration in the ambient air is unreliable. 
(b) Continue scheduled GLEF tests by measuring the flow rate of noncondensible gases as a percent of the total production flow. Analyze the samples of the gases for major constituents and for hydrogen sulfide in particular. Take measurements of hydrogen sulfide in the ambient air so that plant emission and ambient air quality can be interrelated. The advantages are that it is not expensive, long-term prediction for part of the reservoir adjacent to the existing wells is reliable, and the test can be carried out simultaneously with other critical tests. The disadvantages are that the long-term prediction for the whole reservoir is not reliable, data so gained are not reliable for design of a 30-year plant, and ambient air quality prediction is approximate.

(c) Drill additional wells or test other existing wells in the salton sea KGRA to determine the noncondensible gas content on a representative basis. Measure the gas flow as a percent of the total flow for all wells, and analyze the gas from each well for its consituents. Take measurements of hydrogen sulfide in the ambient air and relate to emission from the wells. The advantages are that it will yield more accurate and reliable results for the design of a 30-year plant because the noncondensible gas content in the reservoir is checked on a representative basis and ambient air quality prediction is more accurate. The disadvantages are that it is expensive, time consuming, and long-term prediction may not be accurate.

RECOMMENDED PROCEDURE

Alternative (c) is recommended. The only reliable method of obtaining the needed design information is to operate the required number of wells for a 30-year period. which of course cannot be done: Hence, it is recommended that a multitude of wells be tested for the noncondensible gas content in the reservoir. Without such representative design data, there will always be the risk of reduced steam turbine efficiency and increased auxiliary power demand for handling higher than design noncondensible gas content. A representative analysis will 
reduce this: risk significantly, but risk of high noncondensible gas content in some part of the reservoir will always be present. and this risk cannot be totally eliminated without a complete reservoir survey. It is anticipated that additional wells, perhaps six, or existing wells in the salton sea KGRA, while taking considerable amount of time and money, will yield enough data to reduce the risk to a reasonable level for design and operation of a 30-year plant.

It is essential to have a case history of the air quality in the vicinity of the test facility. In particular, the data should record any problems arising from the development of the geothermal energy resource. An ongoing test program should be instigated to monitor continually the area surrounding the test facility, both when the plant is in operation and when it is shut down. This program should be coordinated with the survey of soil and vegetation, done by Environmental Monitoring and support Laboratory of EPA, in the area surrounding the test facility with a review of the effects on particular crops of noncondensible gases, particularly hydrogen sulfide. In addition, air monitoring stations should be installed for continuous air monitoring. These should be integrated with any local ongoing air quality test program. Also, a computer model to simulate the hydrogen sulfide emission at the plant and its effect on ambient air quality under varying conditions should be developed. The computer work should be correlated with actual measurements of hydrogen sulfide. Use this as a basis for the predicting ambient air quality for projected commercial power plant. This test will 
be conducted with Test No. 10. The cost for this test will be moderate to expensive. 
Test No. 14

RESERVOIR PERFORMANCE

PRIORITY: $\quad B 2$

RISK AREA: $1,2,4,7,9$,

25, and 28

OBJ ECT IVE

- To obtain reservoir data which will give an adequate level of confidence that a sufficient amount of hot geothermal brine will be produced to sustain the operation of the projected commercial power plant over a 30-year life

\section{SIGN IF ICANCE}

Geothermal reservoirs are found in complex geological settings, and well productivity is related to complicated fauls and fracture geometry. Failure of the well field to supply and receive the geothermal brine throughout the life of the plant and at a level to sustain normal power output would involve considerable expense with additional well drilling in an extended area.

ALTERNAT IVE PROCEDURES

No alternative procedures are recommended.

\section{RECOMMENDED PROCEDURE}

The recommended procedure is to continue to expand the information on the reservoir, particularly in the area surrounding the GLEF site. Consideration should be given to utilizing an integrated numerical simulator of the reservoir and 
wellbores, which would be continually updated as new data are obtained from the development of the reservoir. specific tests used to expand information on the well field would be as follows:

- Using existing heat depletion values (gravametric and thermal gradients), assess the potential yield of the area.

- Extrapolate conditions over the proposed 30-year life of the plant using a declining temperature curve analysis.

- Only the permeability in the vicinity of existing wells is known. This information should be expanded to obtain data on the relationship between production and injection wells and the natural recharge of the reservoir. This test could utilize radioactive traces to obtain these characteristics. Core samples should be made of all new wells.

- Improve measurement techniques for wellhead and downhole conditions of pressure, temperature, flow. and brine chemistry.

- Consider the drilling of low cost test holes. particularly in areas where information is sparce.

- Simulate the computer model of the reservoir to study the effect of various methods of production and injection.

- Gather data from other companies about existing wells in Salton sea KGRA.

This test should be carried out independently of the GIEF test: The test should continue to run during design stages of the projected commercial power plant, i.e.., beyond the end of 1978 GLEF test schedule, to update the reservoir data. The test is moderate to expensive and time consuming, and predicted energy production cost will be more reliable and accurate if it is based on established reservoir performance. This test will be performed with Tests No. 10 and No. 13. 
Test No. 15

STEAM CLEANING

PRIORITY: $\quad$ B3

RISK AREA: 14

OBJECTI VE

- To evaluate the performance of scrubbers and mist eliminators in cleaning steam flashed from salton sea brine using the range of operating conditions anticipated for a projected commercial power plant

\section{SIGNIFICANCE}

This test will permit the selection of a de-entrainment device. which will deliver the required steam purity at the minimum pressure drop and the lowest consumption of wash water.

\section{ALTERNATIVE PROCEDURES}

(a) Use the existing GLEF data for scrubber performance, and compare this with widely used mist eliminator performance as published by the industry. The advantage of this procedure is that no additional testing will be performed, hence no additional cost. Existing data are presumed to be sufficient for the selection of a steam cleaning device, (i.e. either scrubber or mist eliminator). The major disadvantages are that no conclusive data for scrubbers, over a wide range of operating conditions, with two-stage flashing, are available for comparison, and no experimental data with brine from salton Sea KGRA exist for the mist eliminator.

(b) Continue to conduct tests with the modified two-stage GLEF on scrubbers to establish the performance as a function of the purity at the inlet, vapor velocity, and wash water flow, so that a whole set of conclusive results can be obtained for comparison with readily avilable data on the performance of mist eliminators. The main advantage is that this procedure does not involve additional capital cost but only additional tests on the existing equipment, probably with some 
modifications. The disadvantage is that the comparison will not be on the same basis, since the available mist eliminator performance is not for cleaning steam flashed from brine of salton sea KGRA.

(c) Install cyclone separators after the flash vessel. The advantages are that it is cheap to operate, it is reliable, enthalpy of the steam is not reduced, and it is efficient for removing relatively large size particulate matter and water droplets. The disadvantages are that there is a considerable amount of pressure drop, pressure drop will increase as the efficiency increases, small size carryover particles that will contribute to scaling and stress corrosion cracking in the turbine cannot be removed effectively, and it will be an additional item of equipment in the power plant.

(d) Design and build four flash vesse1s, two with mist eliminators in one brine train and two others with Hutchinson scrubbers in the other brine train. Test the performance of both types as a function of inlet vapor purity, vapor velocity, and wash water flow. The advantage is that realistic performances over a wide range of operating conditions will be available for comparison and selection without having to rely on extrapolated test results and published performance. The disadvantage is that it is expensive and time consuming.

\section{RECOMMENDED PROCEDURE}

Alternative (d) is recommended. The recommended tests are expensive. They are justified because of the importance of having clean steam under all types of operating conditions for the steam turbine. Iittle is known about the operation of steam turbines in a contaminated steam environment. The large utility turbine generators of today are operating under almost perfect steam conditions with low sodium and chloride limits. It is anticipated that careful design of steam cleaning devices will reduce the contaminants in the turbine inlet steam to that approaching present day utility levels. 
8. 2

OTHER RECOMMENDED ACTIVITIES

There are a number of risk items that need to be examined analytically that do not involve work at the GLEF site. In some instances such work would be required to back up the test work that will be carried out at the GLEF site, and in other instances the study will be independent analytical work with a view toward improving the design and operation of the projected commercial power plant and minimizing a specific risk element. These items are classified as activities, and a separate set of priorities has been assigned to them. Activity format is similar to that of the test format, except that there are no alternative procedures. The cost of each of these activities will be very moderate.

Table 8-3 lists the recommended activities in order of priority and, where applicable, indicates the corresponding risk area from Section 7 .

$8-56$ 
TABLE 8-3

RECOMMENDED ACTIVITIES

\begin{tabular}{|l|l|r|r|r|}
\hline 1 & Energy Cost & 1 & - \\
2 & Disposal of Solid and Liquid Waste & 2 & 24 \\
3 & Water Availability & 3 & 25 & 16 \\
4 & Design Parameters for Flash Vessel & 4 & 19 \\
5 & Condenser and Vacuum System & 5 & 14 \\
\hline
\end{tabular}




\section{Activity No. 1 \\ ENERGY COST}

PRIORI TY: 1

RISK AREA: NONE

OBJECTI VES

- To update the energy cost in the light of results of the tests outlined herein and further study of component costs, and to compare the results with energy costs from conventional sources

- To estimate the energy costs for other processes that may have better performance than the flashed steam process

\section{SIGNIFICANCE}

This study will refine the initial prediction of the energy costs for a 50 MWe plant at the salton sea KGRA, using the flashed steam process. Other high-performance processes should be inve stiga ted.

\section{RECOMMENDED PROCEDURE}

Design parameters of the conceptual power plant should be updated to reflect data from the tests and studies of this test program. The economic impact of such changes should be evaluated. Competitive sources for the plant components should be explored, and the resulting variations in energy costs should be calculated. capital cost and energy cost estimates should be made for other processes that may be found to have improved performance over the flashed steam process. 
Activity No. 2

DISPOSAL OF SOLID AND IIQUID WASTE

PRIORITY: 2

RISK AREA: 16

OBJ ECT IVES

- To investigate disposal and, preferably, sale of solid wastes generated by the plant

- To evaluate alternative methods for disposal of cooling tower blowdown

\section{SIGNIFI CANCE}

Disposal of solid and liquid wastes present environmental risks that may have a strong impact on capital and operating costs.

\section{RECOMMENDED PROCEDURE}

The logistics and economics of alternative methods for disposal of solid and liquid wastes should be investigated. The solid waste would result primarily from settling pond or clarifier sludge, scale removal, and the stretford process. Liquid waste would primarily consist of purge from the stretford process and blowdown from the cooling tower. The marketability and cash returns from sale of some or all of the constituents of the solid wastes should be determined.

The technical aspects and relative costs of alternatives for disposing of cooling tower blowdown should be studied. Among the possibilities are use of steam condensate in the cooling system, resulting in only a small amount of cooling system blowdown. 
This approach will not be appropriate if the injection flow rate must be equal to the production flow rate so that ground subsidence can be prevented. Also, the use of irrigation drainage or river water as cooling system makeup should be studied. This would result in substantial blowdown that may be injected. In this case, the blowdown will probably need to be treated before injection and this will be expensive. As an alternative, cooling tower blowdown could be discharged to the salton sea or to evaporation ponds located adjacent to the proposed power plant. 
Activity No. 3

WATER AVAILABIIITY

PRIORI TY: 3

RISK AREA: 19

OBJECTI VE

- To establish a realiable source of water for power plant requirements

\section{SIGNIFICANCE}

Capital and operating costs will be significantly affected.

\section{RECOMMENDED PROCEDURE}

The relative effects of the following on the plant capital and operating costs should be studied.

- Use of steam condensate for plant water requirements, assuming that it is acceptable to inject less than 100 percent of production flows.

- Use of steam condensate for plant water requirements while using irrigation drainage water, river water, or salton sea water as injection makeup, assuming 100 percent injection is required. Also, the treatment required for outside water to make it compatible with injection brine should be established.

- Use of irrigation arainage water, river water, or Salton sea water for plant water requirements. assuming 100 percent infection is required and steam condensate is used for injection. Also. the treatment required for such a makeup water source should be established. 


\author{
Activity No. 4 \\ DESIGN PARAMETERS FOR FIASH VESSEL
}

PRIORITY: 4

RISK AREA: 14

OBJECTI VE

- To establish a method for obtaining controlled

flashing in a flash vessel and design parameters for such method

\title{
SIGNIFI CANCE
}

A proper flash vessel design is important in producing a steady. continuous flow of good quality steam for the turbine, when flashing high temperature, high salinity salton sea brine.

\section{RECOMMENDED PROCEDURE}

The flash vessel design should be studied on the bases of brine inlet structure, its internals, release area, disengagement height, and turbulence. A criterion for flash vessel design should be established and some scale model testing performed. 


\author{
Activity No. 5 \\ CONDENSER AND VACUUM SYSTEM
}

PRIORITY: 5

RISK AREA: 15

OBJECTIVE

- To establish the optimum combination of surface area and tube layout for the main condenser and the optimum vacuum system.

\title{
SIGNIFICANCE
}

selection of proper equipment will result in efficient power plant operation and realistic estimates of capital cost.

\section{RECOMMENDED PROCEDURE}

The effect that gas cooling surface area in the condenser has on the required capacity of the vacuum system should be studied. The advantages and disadvantages of steam ejectors and vacuum pumps should be evaluated in terms of capital cost and operating load. Both types, or a combination of the two, should be matched with the surface condenser to arrive at an optimum system on the basis of minimum energy production cost. The effect of noncondensible gas on the area required and tube layout in the surface condenser should be studied. 
APPENDIX A

COST ESTIMATING METHODOLOGY 
Appendix A

COST ESTIMATING METHODOLOGY

A. 1 INTRODUCTION

The conceptual design of each system will provide sufficient detail for estimating:

- Total capital cost

- Energy production cost

The total capital cost is made up of the power plant capital cost and the well field capital cost.

Energy production costs, estimated separately for the power plant and well field and expressed in mills per kilowatt-hour, are based on recovering the following costs over the commercial life of the geothermal power plant and field:

- All invested capital

- A satisfactory return on invested capital

- All expenses

- Income and ad valorem taxes

The estimates will be at first quarter 1982 price and wage levels; commercial operation of the plant is assumed to be attained during the first quarter of 1982. All dollar amounts given in Appendix A are for first quarter 1978, except where noted. 
Escalation is applied to the construction costs, which are estimated in first quarter 1978 dollars on the following basis:

- For all materials, including raw materials and finished goods, the rate is 6 percent per annum through 1984 and $4-1 / 2$ percent thereafter.

- For all construction labor, including indirect labor, the rate is 8 percent per annum through 1984 and $6-1 / 2$ percent thereafter.

A. 2 CAPITAL COSTS - PCWER PLANT

The power plant capital construction cost is made up of direct field construction costs, indirect field costs, engineering services, contingency, escalation, allowance for funds during construction, and other owner's costs. Table A-1 shows an example of a power plant capital cost breakdown.

A. 2. 1 Direct Field Construction Costs

The following cost estimating methods will be used to develop the direct field construction costs:

Equipment:

- Cost of mechanical equipment. as listed in the equipment list will be based on either manufacturers' estimates or estimated using current prices from industrial sources.

- Research and development costs will not be included.

- Miscellaneous mechanical equipment will be estimated from industrial experience as a percentage of major mechanical equipment. 
TABLE A-1

CAPITAL COST ESTIMATE - POWER PLANT

50 MWe (NET) DUAL FLASH ENERGY CONVERSION

SALTON SEA KGRA, NILAND, CALIFORNIA

\begin{tabular}{|c|c|c|}
\hline & $\begin{array}{l}\text { Labor } \\
\$ 1,000\end{array}$ & $\begin{array}{l}\text { Material } \\
\$ 1,000\end{array}$ \\
\hline $\begin{array}{l}\text { Mechanica1 Equipment } \\
\text { Turbine Generator } \\
\mathrm{H}_{2} \mathrm{~S} \text { Abatement System } \\
\text { Tanks and Vessels } \\
\text { Condenser and Vacuum Equipment } \\
\text { Cooling Tower } \\
\text { Pumps and Drives } \\
\text { Other Mechanical } \\
\text { Piping and Instrumentation } \\
\text { Electrical } \\
\text { Civil/Structural } \\
\text { Yardwork and Miscellaneous }\end{array}$ & & \\
\hline $\begin{array}{l}\text { Direct Field Cost } \\
\text { Indirect Cost a } 65 \% \text { of Direct Labor } \\
\text { Total Field Cost } \\
\text { Engineering Service d } 14 \%\end{array}$ & & \\
\hline $\begin{array}{l}\text { Total Field Plus Engineering Cost } \\
\text { Contingency @ 20\% } \\
\text { Total Construction Cost } \\
\text { First Quarter } 1978 \text { Dollars } \\
\text { Escalation }\end{array}$ & & \\
\hline $\begin{array}{l}\text { Construction Cost Plus Escalation } \\
\text { Owner's Cost d } 8 \% \\
\text { Capital Cost Before AFDC } \\
\text { AFDC }\end{array}$ & & \\
\hline $\begin{array}{l}\text { Total Capital Cost } \\
\text { First Quarter } 1982 \text { Dollars }\end{array}$ & & \\
\hline TOTAL & & \\
\hline
\end{tabular}


- Cost of electrical equipment will be factored based on industrial experience.

\section{Structures:}

- Turbine and control building will be estimated on a cost per square foot basis.

- Other civil/structural costs will be estimated from the plot plan.

Bulk Materials. Quantity estimates will be made for the identifiable bulk materials of concrete, steel, piping, etc. from drawings and equipment lists. These quantities will be priced using current unit prices from industrial sources. Other materials such as small piping and instrumentation that would be delineated on final engineering drawings will be evaluated from experience as a percentage of the identifiable bulk materials.

Construction Labor costs. The direct construction labor costs will be estimated using a wage rate of $\$ 17$ per hour. This rate includes an allowance of $\$ 2.00$ per hour for travel and subsistence and fringe benefits (FICA, FUI, and sUI dues and workmen's compensation insurancel. It also includes an allowance of 5 percent for casual overtime and 1 percent for craft furnished supervision.

\section{A.2.2 Indirect Field costs}

The indirect field costs are those items of construction cost that cannot be ascribed to any specific construction operation for the permanent facilities and are thus accounted separately. 
The items covered by indirect field costs include the following:

- Temporary Construction Facilities: temporary buildings, working areas, roads, parking areas, and utility system and general purpose scaffolding.

- Miscellaneous Construction services: general job cleanup, maintenance of construction equipment and tools, material handling, and surveying.

- Construction Equipment and Supplies: construction equipment, small tools. consumable supplies, and purchased utilities.

- Field office: labor for craft supervision, field engineering, procurement, scheduling, personnel administration, warehousing, first aid, and the costs of the field office.

- Preliminary Checkout and Acceptance Testing: Iabor, materials, supplies, and equipment to insure that components and systems are operable.

- Project Insurance: public liability. property damage, and builder's risk insurances.

- Taxes and permits: state and local taxes and permits.

The indirect costs will be computed at 65 percent of direct construction labor costs.

A. 2. 3 Engineering Services

The engineering services include engineering costs, and the fee. Engineering includes preliminary engineering, optimization studies, specifications, detailed engineering, review of vendor drawings, site investigation, and support to vendors. Other home office costs include procurement, estimating and scheduling services, quality assurance, and project management. The fee is included as a function of the total project cost. A figure of 14 
percent of total field construction costs will be used for engineering services. Engineering services are considered to be 100 percent labor related.

\section{A. 2.4 Contingency}

Included in the estimate will be a contingency allowance for the uncertainty within the conceptual design in the quantity, pricing, or productivity that is under the control of the constructor and within the scope of the project as defined. The contingency cannot be considered as a source of funds for additions to the project scope. It is suggested that, for the purpose of comparing the several conceptual designs in this study, a 20 percent contingency be applied to the subtotal of field construction cost plus engineering services as shown in Table A-1. It is assumed that 80 percent of the contingency is labor-related and 20 percent materials-related.

\section{A.2.5 Escalation costs}

The total construction period is assumed to be 40 months begining september 1978. For computation of escalation costs, the center of gravity of escalation is assumed to occur at approximately the two-thirds completion point of the construction schedule. This is calculated to be 2.89 years from the beginning of 1978 or 1.11 years before the beginning of 1982 . 


\section{A. 2.6 other Owner's costs}

These include the Owner's general office and accounting costs, startup and operator training, owner's engineering and management, site and environmental impact studies. They also include spare parts and inventory costs, licenses, permits, and taxes during construction. A figure of 8 percent of total construction cost including escalation will be used. These costs are assumed to be distributed 80 percent to Iabor and 20 percent to material.

\section{A.2.7 Allowance for Funds During Construction (AFDC)}

The bulk of AFDC is composed of interest costs. The center of gravity of cash flow occurs at apcroximately the two-thirds completion point of construction. AFDC will therefore be calculated by using 8 percent per annum compound interest on the total escalated construction cost plus owner's costs over a period of one-third of the construction schedule, i.e..1.11 years. These costs will be prorated proportionately to labor and materials. 
A. 3

CAPITAL COSTS - WELL FIELD

A.3.1 Direct Field Costs

- The production and injection wells will be installed on a subcontract basis including drilling, carbon steel casing, and wellshead equipment. Production well will cost $\$ 300,000$ each, and injection wells will cost $\$ 200,000$ each.

- Spare wells will be included at 20 percent of the production and injection wells.

- The original number of both production and injection wells, including spares, will be replaced during the life of the plant. The replacement wells will be installed linearly over the plant lifetime.

- Supplier's estimates will be obtained for the preinsulated production and injection brine piping.

- The direct construction labor costs will be estimated using a wage rate of $\$ 17$ per hour as described in section A-2. 1 .

A.3. 2 Indirect Field costs

Indirect field cost will be taken as 65 percent of the direct field construction labor as described in section A-2.2.

A. 3. 3 Engineering Services

Engineering services will be taken as 14 percent of the field construction costs (excluding well costs) as described in section A-2. 3. 


\section{A.3.4 Contingency}

For comparative purposes, it is suggested that a 20 percent contingency allowance be applied to the subtotal field investment estimate (excluding well costs) in a manner similar to that shown in Table A-1. This allowance is described in section A-2.4.

\section{A. 3. $5 \quad$ Escalation Costs}

The total construction period is assumed to be 20 months beginning May 1980. For the computation of escalation costs, the center of gravity of escalation is assumed to occur at approximately the two-thirds completion point of the construction schedule. This is calculated to be 3.44 years from the beginning of 1978 or 0.56 year before the beginning of 1982 .

\section{A.3.6 Owner's costs}

No owner's cost allowance will be assumed applicable to well field investments.
A. 3.7
Allowance for Funds During Construction (AFDC)

The bulk of AFDC is composed of interest costs. The center of gravity of cash flow occurs at approximately the two-thirds completion point of construction. AFDC of the well field will be estimated at 8 percent per annum compound interest on the total escalated cost plus owner's cost over a period of one-third of 
construction schedule, i.e.. 0.56 year. These costs will be prorated proportionately to labor and materials.

A.4. ENERGY PRODUCTION COSTS - POWER PLANT

The costs of energy produced from the power plant relates to capital investments that are amortized over the life of the project and recurring annual costs that are expended in the year incurred. These include:

- Capital charges including the cost of capital and capital recovery

- Income taxes

- operation and maintenance expenses

- Administration and general expenses

- Plant insurance

- Ad valorem taxes

\section{A. 4. 1 Capital Charges}

Power plant capital investments are detailed in section $A-2$. Calculation of capital charges include the following assumptions.

- An 11 percent discounted cash flow rate of return will be applied to all power plant capital investments.

- Straight line book depreciation will be used for capital recovery purposes, and equipment lifetime will be assumed to be 30 years.

- Salvage value will be zero at the end of plant life.

- Power plant economic life will be 30 years. 


\section{A.4.2 Income Taxes}

- Federal income tax rate of 48 percent will be used and equipment lifetime of 23 years will be assumed for federal taxes.

- State income tax rate of 9 percent will be used and equipment lifetime of 28 years will be assumed for state taxes.

- Accelerated depreciation (200 percent declining balance switching to straight line) will be used for income tax purposes.

- For all capital investments. 5 percent will be claimed as investment tax credit for federal tax purposes.

- Power plant capital will be assumed to be 50 percent debt, 15 percent preferred equity. 35 percent common equity. Tax deductible annual interest rate on debt is 9 percent; annual interests on preferred and common equity are 9 percent and 14.5 percent, respectively.

\section{A.4.3 Operation and Maintenance Cost}

Operation and maintenance expenses based on first quarter 1982 levels for the four cases are shown in Table A-2. The cost of operating labor is assumed to escalate at an annual rate of 6 percent through 1984 and $4-1 / 2$ percent thereafter.

\section{A.4.4 Administration and General Expenses}

Administration and general expenses will be 25 percent of the annual operation and maintenance expense. 
TABLE A-2

OPERATION AND MAINTENANCE COST ${ }^{(1)}$

50 MWe (NET) DUAL FLASH ENERGY CONVERSION
SALTON SEA KGRA, NILAND, CALIFORNIA

\begin{tabular}{|c|c|c|c|c|}
\hline & \multicolumn{2}{|c|}{$\begin{array}{c}\text { No Minimum Injection } \\
\text { Temperature Limit }\end{array}$} & \multicolumn{2}{|c|}{\begin{tabular}{|c}
300 Injection \\
Minimum Temperature Limit
\end{tabular}} \\
\hline & Unmodified & Acidified & Unmodified & Acidified \\
\hline $\begin{array}{l}\text { Power Plant Operation and Maintenance Cost } \\
\text { Maintenance Cost (including } \\
\text { overhaul, etc.)(2) } \\
\text { Operators; Two/Day Shift }+ \text { One/ } \\
\text { Night Shift (crew of nine) (2) } \\
\text { Supervisor (2) + Shift Engineer } \\
+ \text { Office } \\
\text { Operator for Stretford (one/shift; } \\
\text { crew of five) (2) } \\
\text { Scale Removal (labor and chemical) (3) } \\
\text { Brine Treatment (acid and caustic) } \\
\text { Solid Hauling } \\
\text { Items indicated above make up the } \\
\text { total plant operation and mainten- } \\
\text { ance cost. (See Section A- } 4.3 \text { of } \\
\text { this appendix.) } \\
\text { Well Field Operation and Maintenance Cost } \\
\text { For Scale Removal (6) } \\
\text { Scale Removal } \\
\text { Field cost item is in addition to } \\
\text { fleld cost 1tems listed. (See } \\
\text { Section A-5.4 of this appendix). }\end{array}$ & $\begin{array}{l}\$ 190,000 / y r \\
\$ 285,000 / y r \\
\$ 95,000 / y r \\
\$ 158,000 / y r \\
\$ 133,000 / y r \\
\text { Not Required } \\
\$ 32 / \text { hour }\end{array}$ & $\begin{array}{l}\$ 190,000 / y r \\
\$ 285,000 / y r \\
\$ 95,000 / y r \\
\$ 158,000 / y r \\
\text { Not Required } \\
\$ 85 / \text { hour } \\
\$ 32 / \text { hour }\end{array}$ & $\begin{array}{l}\$ 190,000 / y r \\
\$ 285,000 / y r \\
\$ 95,000 / y r \\
\$ 158,000 / y r \\
\$ 101,000 / y r \\
\text { Not Required } \\
\text { Not Required }\end{array}$ & $\begin{array}{l}\$ 190,000 / y r \\
\$ 285,000 / y r \\
\$ 95,000 / y r \\
\$ 158,000 / y r \\
\text { Not Required } \\
\$ 93 / \text { hour } \\
\text { Not Required }\end{array}$ \\
\hline
\end{tabular}

Notes:

(1) Based on first quarter 1982 dollars.

(2) Items are based on first quarter 1978 dollar cost at Geyser, which was obtalned from PG\&E. Supervisory and operator costs for Salton Sea KGRA allow for added work associated with brine handing system

(3) GLEF cost is $\$ 15,000$ for two weeks. ( $\$ 7,500$ for labor $+\$ 7,500$ for chemlcals). Power plant scale removal is to take place every 1000 hours for two weeks. Hence labor cost 1 s $\$ 7,500$. Chemical cost is prorated from GLEF areas of vessel, interconnecting piping, and $500 \mathrm{ft}$ of injection piping.

(4) Based on $100 \%$ plant flow capacity; acid concentration of $120 \mathrm{ppm}$, acid cost $\$ 0.10 / 1 \mathrm{~b}$; caustic concentration of $20 \mathrm{ppm}$, caustic cost $\$ 0.07 / 1 \mathrm{~b}$ (Ref. George Tardiff, LLL).

(5) In the settling pond, solids, precipitate out at the rate of $5001 \mathrm{~b} / 1,000,0001 \mathrm{~b}$ of brine. Centrifuge cake is $50 \%$ solids. It costs $\$ 10 /$ ton to haul. Applicable to $100 \%$ plant flow capacity.

(6) No minimum infection temperature limit (with settling pond) case: field piping is assumed to be cleaned every three years. In $300 \mathrm{~F}$ case (no pond), injection line needs to be cleaned every 1000 hours, production line once every three years. 
A.4.5 Plant Insurance

Insurance will be 0.1 percent of the power plant capital cost annually.

A.4.6 Ad-Valorem Tax

Annual ad valorem tax on power plant will be in the form of property tax. This will be 2.4 percent of plant value based on the initial cost of the plant depreciated linearly over the plant life, but escalated at an annual rate of 5.5 percent.

A.4.7 Power Plant Energy Production Cost Estimating Approach

The power plant energy production cost will be estimated by dividing the sum of levelized annual capital charges and operating costs (in mills) by the level annual net electrical energy output of the power plant (in kilowatt-hours). plant (in kilowatt-hours).

- Net level electric power output of plant will be 50 MWe.

- Plant level capacity factor will be determined for each case as outlined in section 4.2 .3 of the main report. 
The cost of producing energy from the well field comprises all costs of geothermal wells and surface facilities up to the power plant site boundary. The costs will include:

- Capital charges including the cost of capital and capital recovery

- Income taxes

- Operation expenses

- Maintenance expenses

- Administration and general expenses

- Ad valorem taxes

- Royalties

\section{A.5.1 Capitalization of Investments}

well field capital investments are detailed in section A.3 of this Appendix. Calculations of capital charges involve the following assumptions.

- A 20 percent discounted cash flow rate of return will be applied to all well field capital investments.

- Straight line book depreciation will be used for capital recovery purposes.

- Salvage value will be zero at the end of field economic life.

- Well field economic life will be 30 years. 


\section{A.5.2 Income Taxes}

- Federal income tax rate of 48 percent will be used. and equipment lifetime of 23 years will be assumed for federal taxes.

- State income tax rate of 9 percent will be used and equipment lifetime of 28 years will be assumed for state taxes.

- Accelerated depreciation 1200 percent declining balance switching to straight line) will be used for income tax purposes.

- No depletion allowances or expending of intangible well costs will be allowed.

- For all capital investments, 5 percent will be claimed as investment tax credit for federal tax purposes.

- Well field capital will be assumed to be 100 percent equity financed.

\section{A.5.3 Operation}

Annual operating expenses for the well field facilities include the following estimates:

- Foreman's and site manager's salaries and associated overhead at $\$ 70,000$ per year.

- Field operators'. roustabouts', electrical and instrumentation technicians'. mechanics ${ }^{\circ}$. mechanical engineers', and well engineers' salaries and associated overhead plus operating chemicals and other materials for a base case field of six production wells and associated injection wells at $\$ 150,000$ total per year.

- Cost of scale removal for the surface piping. is shown in Table A-1.

The operating labor cost is assumed to escalate at an annual rate of 6 percent through 1984 and $4-1 / 2$ percent thereafter. For well 
fields having other than six production wells, the $\$ 70,000$ annual expense for foremen and the site manager remains unchanged, but a factor of:

$$
\text { No. of Production Wells } 0.3
$$

is applied to the $\$ 150,000$ expense assumed for other salaries and operating materials.

\section{A.5.4 Maintenance Cost}

Annual well field maintenance expense will include 0.5 percent of the capital cost of the surface facilities for both production and injection wells, plus $\$ 40,000$ per injection well for rework. No rework will be included for production wells; defective wells are assumed to be replaced.

\section{A.5.5 Administration and General}

Annual administration and general expenses for the well field will be 10 percent of the annual operation and maintenance expense of the well field. 

A. 5.6
Ad Valorem Tax

Annual ad valorem tax on the well field will be in the form of a production tax of 10 percent of the gross revenue of the well $f i \in 1 d$.

A. $5.7 \quad$ Royalties

Royalties will be 10 percent of the gross well field income.

A. 5.8 Insurance

Well field insurance will be assumed to be negligible.

A.5.9 Reservoir Exploration, Confirmation, and Engineering

These costs will be assumed to be included in the 20 percent risk-adjusted rate of return on well field capital investments.

A.5.10 Well Field Energy Production Cost Estimating Approach

The well field cost of energy will be estimated by dividing the sum of levelized annual capital charges and operating costs for the well field (in mills) by the level annual net electric energy output of the power plant (in kilowatt-hours). 
- Net level electric power output of plant will be 50 MWe

- Plant level capacity factor will be determined for each case as outlined in section 4.2 .3 of this report. 


\section{APPENDIX B \\ PROJECT CONFERENCE REPORTS}

(This appendix contains the reports from periodic review meetings which were conducted by SDGEE throughout the study) - 
CONFERENCE NOTES

Feasibility Study of a Geothermal Power Plant

at the Salton Sea KGRA

Distribution:

T. Hinrichs - Magma

W. Jacobson - SDG\&E

P. Kasameyer - LLL

R. Schoeder - LBL

A. Sims - Ben Holt

J. Hankin - Bechtel

A. Renton - Bechtel

A. Rogers - Bechtel

K. Mirk - LBL

Attendance:

T. Hinrichs

W. Jacobson

P. Kasameyer

R. Schroeder
Date of Conference: November 1, 1977

Subject: Reservoir and Well Data

Prepared by: J. W. Hankin

Bechtel Corporation and The Ben Holt Company are each to perform cycle analyses for the feasibility and risk analysis study of a geothermal power plant at the Salton Sea KGRA. Bechtel will perform studies for a dual flash cycle and Holt will perform studies for a multistage flash/binary cycle. The purpose of this meeting was to select common reservoir and well design data to be used in these studies.

A copy of the agenda for the meeting is attached. It was prepared by Bechtel and reviewed with A. Sims of Holt prior to the meeting. The data agreed upon and assignments for further study are listed below in numerical order, corresponding to the agenda:

1. Supply We11s

1.1

1.2

1.3

1.4
(A11 data at well head conditions)

Temperature at design flow rate $=370 \mathrm{~F}$ (decreases with time as described in Item 1.3 below).

Pressure at design flow rate $=150$ psig (constant over plant lifetime).

Quality of fluid = variable with time (calculate by assuming enthalpy is constant from well bottom to well head, initial temperature at well bottom is $478 \mathrm{~F}(248 \mathrm{C})$, and well bottom temperature declines linearly $18 \mathrm{~F}$ (10C) in 30 years).

Dissolved solids concentration $=20 \% \mathrm{TDS}$. 
2.5

2.6

2.7

2.8

2.9

2.10

\section{Reservoir}

3.1

3.1 .1

3.1 .2

3.1 .3

3.2
Depth of well.

Casing diameter.

Well spacing and pattern.

Discussed in the following paragraph Distance of reinjection
of production field.

Vertical, or slant-drilled from island?

Number (\%) of spare wells.

Magma will study Items 2.5 through 2.10 . It was tentatively indicated that reinjection wells would be 2,500 feet deep.

Define the reservoir under consideration.

Deep or shallow reservoir?

High- or medium-temperature reservoir?

Discussed in the following paragraph

The number of MWe each the two types is capable of supporting?

Tom Hinrichs indicated that it has not been proven whether two distinct reservoirs (an upper reservoir with moderate temperature and a deeper reservoir with high temperature) exist. If two reservoirs actually exist, then up-welling may result in communication between them. In effect, the result would be one reservoir. Reinjection may be arranged in a way to force this situation. Paul Kasameyer, Ron Schroeder and Tom Hinrichs agreed that the present GLEF site is located at approximately the center, or hottest portion of what appears to be an upper reservoir. Assuming that two reservoir do exist, it was estimated that about one-third of the total energy is contained in the upper reservoir and two-thirds in the lower. System Science and Software $\left(S^{3}\right)$ has performed a reservoir study on the Salton Sea KGRA which is about to be published. It may include some information that will be useful for the feasibility study.

Pressure and flow decay rates of the selected reservoir for a production of:

$$
\begin{aligned}
& \text { - } 100 \mathrm{MWe} \\
& \text { - } 200 \mathrm{MWe} \\
& \quad 300 \mathrm{MWe}
\end{aligned}
$$

Decay rates are described in Items 1.1 through 1.6 above. 
1.5 Noncondensable gas content $=0.5 \mathrm{wt} . \%$ of total brine flow

Noncondensable gas composition is listed below:

\section{Percent by Volume}

$\begin{array}{ll}\mathrm{CO}_{2} & 98.47 \\ \mathrm{CH}_{4} & 0.81 \\ \mathrm{~N}_{2} & 0.09 \\ \mathrm{H}_{2} & 0.62 \\ \mathrm{H}_{2} \mathrm{~S} & 820 \mathrm{ppm}\end{array}$

The noncondensable gas composition listed above includes averaged values of Woolsey gas analyses taken on $3 / 2 / 77,4 / 7 / 77$ and $4 / 19 / 77$, as reported in the May 1977 Bi-Monthly GLEF Report.

1.6 Design flow rate per well = varies linearly from $400,000 \mathrm{lb} / \mathrm{hr}$ initially to $300,000 \mathrm{lb} / \mathrm{hr}$ at year 30 .

1.7 Well casing diameter.

1.8 Well depth.

1.9 Well spacing and pattern.

1.10 Vertical, or slant-drilled from islands?

1.11 Number (\%) of spare wells.

Magma will study Items 1.7 through 1.11. Tentatively, it was indicated that production wells would cost $\$ 250,000$, they would be 1,500 to 2,500 feet deep and would have $95 / 8$ inch casings.

2. Reinjection

2.1 Requirement on minimum temperature $=$ no limit and $300 \mathrm{~F}$ (two cases are to be considered).

2.2 Pressure requirement at design flow rate $=400$ psig (corresponding to the no limit case in Item 2.1 above) and 465 psig (corresponding to the $300 \mathrm{~F}$ case).

2.3 Design flow rate per well $=600,000 \mathrm{lb} / \mathrm{hr}$ (for both cases in Item 2.1).

2.4 What pretreatment is required? LLL, LBL, Magma and SDG\&E will study. 


\section{CONFERENCE CALL}

November 1, 1977

Page Four

3.3 Changes in composition of production fluid with time under the three production rates of Item $3.2=$ no change with time

4. Scaling and Corrosion
4.1
Scaling consituents.
4. 2
Scaling rates.
4.3
Scale cleaning methods.
4.4
Materials of construction and corrosion rates.

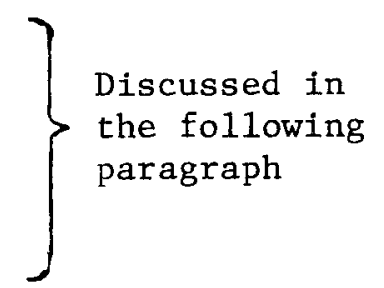

LLL will provide information on scaling, corrosion and materials of construction. It is intended that these feasibility studies be conducted assuming no acidification, but LLL will take this under advisement.

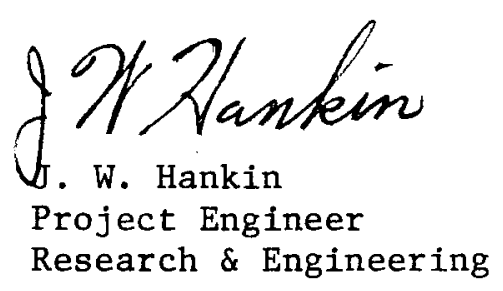


CYCLE ANALYSIS FOR

SDG\&E FEASIBILITY REPORT

Reservoir and Well Design Data

1. Supply Wells

\section{1 .}

1.2

1.3

1.4

1.5

1.6

1.7

1.8

1.9

1.10

1.11

(A11 data at well head conditions)

Temperature at design flow rate. Pressure at design flow rate. Quality of fluid. Dissolved solids concentration. Noncondensible gas content and composition. Design flow rate per well. Well casing diameter. Well depth. We11 spacing and pattern. Vertical, or slant-drilled from islands? Number $(\%)$ of spare wells.

2. Reinjection

2.1

2.2

2.3

2.4

2.5

2.6

2.7

2.8

2.9

2.10

3. Reservoir

3.1

3.1 .1

3.1 .2

3.1 .3

3.2

3.3
Requirement on minimum temperature.

Pressure requirement at design flow rate. Design flow rate per well. What pretreatment is required?

Depth of well. Casing diameter. We11 spacing and pattern. Distance of reinjection wells from center of production field.

Vertical, or slant-drilled from island?

Number (\%) of spare wells.

Define the reservoir under consideration.

Deep or shallow reservoir?

High- or medium-temperature reservoir?

The number of MWe each the two types is capable of supporting?

Pressure and flow decay rates of the selected reservoir for a production of:

- $100 \mathrm{MWe}$

- $200 \mathrm{MWe}$

- $300 \mathrm{MWe}$

Changes in composition of production fluid with time under the three production rates of Par. 3.2. 
4. Scaling and Corrosion
4.1
4.2
4.3
4.4
Scaling consituents
Scaling rates
Scale cleaning methods
Materials of construction and corrosion
rates 
Feasibility Study of a Geothermal Power Plant at the Salton Sea KGRA

Distribution:

T. R. Fick - Bechtel

J. W. Hankin - Bechtel

S. B. Hebbar - Bechtel

A. Renton - Bechtel

A. N. Rogers - Bechtel

T. E. Walsh - Bechte1

B. Holt - Ben Holt

A. Sims - Ben Holt

M. Scheve - DOE

K. F. Mirk - LBL

A. L. Austin - LLL

G. E. Tardiff - LLL

T. C. Hinrichs - Magma

W. O. Jacobson - SDG\&E
Date of Conference: November 30, 1977

Location: Bechtel Corporation

San Francisco

Subject: $\quad$ Status Review

Prepared by: A. Renton

\section{Attendance:}

T. R. Fick

H. W. Hankin

T. E. Walsh (part-time)

S. B. Hebbar

W. O. Jacobson

A. Renton

B. Holt

A. N. Rogers (part-time)

A. Sims

G. E. Tardiff

\section{Schedule}

Holt proposed to complete their designs by the end of 1977 and to submit their draft report by the end of January, 1978.

The Bechtel draft work statement for the feasibility study was discussed briefly.

SDG\&E stated they require the study draft report by mid-January 1978 and requested Bechtel and Holt to prepare an integrated schedule to meet this date. If the mid-January date cannot be met, reasons will be given.

\section{Feasibility Study Report}

SDG\&E stated that the first part of the report should contain the individual conceptual cycles by Bechtel and Holt, after each company has reviewed the other's design to ensure comparable design bases. 
CONFERENCE NOTES

November 30,1977

Page Two

The second part will be a presentation of a common set of conclusions regarding the selection of a preferred cycle or that the studies should be carried forward with both the flash and the binary cycle. It will also include feaslbility, risk analyses and recommendations for future GLEF testing. SDG\&E will use the feasibility study to decide on the best plant design for the Salton Sea site and to institute support work, including additional GLEF testing, to ensure that this will be a minimum risk plant.

\section{Design Data}

The following summarizes the discussion and agreements among the participants:

- Brine: The properities of the brine will be from LLL computer program BPROP2. The well head conditions, agreed upon at the meeting of November 1, 1977 have been revised. The pressure at design flow rate has been kept at 150 psig, but the equivalent saturated temperature will be $381.3 \mathrm{~F}$, as calculated by the computer program.

- Turbine Efficiency: Turbine efficiencies have been requested from several turbine manufacturers for the specific conditions of this study. These efficiencies will be used in the conceptual designs if they are supplied within a compatible time schedule.

To comply with recent antitrust rulings, SDG\&E has sent a letter to GE confirming that they were the originators of the feasibility study.

- Wellfield: The geothermal well field layout will be based on an earlier study by Holt. After modification to show one injection well to two production wells, the layout drawing No. 7506-D-3202 was distributed. The modification deletes Injection Wells $17,18,21,22,25$, and 28 .

An alternative well field concept using the island approach and slant drilling may be considered at a later date.

- Makeup Water: SDG\&E stated that, superseding previous instructions, condensate will be used as makeup water to the cooling water system with an emergency backup water 
The possible reaction of the condensate with the inhibitors which are added to the cooling water will be considered.

- Blowdown: Cooling water blowdown will be discharged to the Salton Sea. However, the blowdown pipe will be shown on drawings and its cost will be estimated only to the power plant boundary.

- Brine Handling: It will be assumed that the brine will be acidified for scale control at entry to the plant and will be neutralized in an effluent treatment system similar to the existing Magma GLEF holding tanks as it leaves the plant site. LLL's material recommendations for the plant and piping will be considered and, if used, confirmed. These are given in the LLL letter, dated November 29, 1977, to SDG\&E and are as follows:

Temperature $>150 \mathrm{C}$ - Hastelloy C-276 liners or monolith. $1 \mathrm{Cr}, 1 / 2$ Mo alloy steel or equivalent may a1so be acceptable.

Temperature $<150 \mathrm{C}, \mathrm{pH}<5-1 \mathrm{Cr}, 1 / 2$ Mo alloy steel or equivalent, temperature $\langle 150 \mathrm{C}, \mathrm{pH}\rangle 5$ - carbon steel.

These recommendations apply to acidification brine ( $\mathrm{pH} 4.5$ ) as well as unmodified brine. It was noted that carbon steel would not be suitable for high temperature components in unmodified brine, such as production wells and piping.

- Mechanical Cleaning: SDG\&E has gained experience in cleaning scale buildup in GLEF vessels and drain lines by inhibited acid soaking and hydroblasting. Their experience indicated that for a 1000 hour cycle, the cost was $\$ 15,000$ and required $1 \frac{1}{2}$ weeks downtime with the plant operators also performing cleaning operations. With unmodified brine, scale buildup rate will be considered to be one mil per hour downstream of the first flash tank. Scale build up upstream of the first flash tank can be ignored.

- Injection Pumps: Even with acidification, redundant injection pumps are required, 3 d $50 \%$ capacity pumps will be provided in the study.

- Brine Production Lines: The run of these lines to the site will require careful design to ensure steady flow with two phase flow conditions. Risk and confidence will be indicated 
in the report. The higer allowable pressure drop in the line for the flash system could reduce the design problems for this cycle. However, for the binary system, a low pressure drop is needed. Therefore, use of separators at the wellhead and separate brine and steam lines to the plant will be considered.

- Steam Cleanup: The system currently being considered for the flash cycle is a mist eliminator/scrubber. Although this type of system has been used successfully in desalination plants, it has not operated with the brine concentrator at the Salton Sea. The Hutchison design, in use at the GLEF, will be considered and Holt will supply design criteria for Bechtel's steam conditions.

- Liquid to Liquid Binary Cycle: Acidification of the brine in the plant will reduce scaling and enable liquid to liquid heat exchangers to be used in the binary system. This will require an additional conceptual design by Holt and have an impact on the time schedule which Holt agreed to assess.

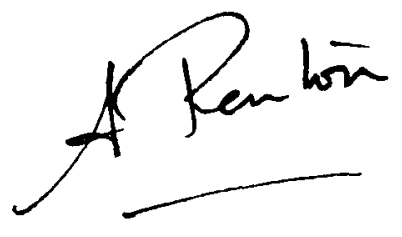

A. Renton

$\mathrm{AR} / \mathrm{cm}$ 
CONFERENCE NOTES

Feasibility Study of a Geothermal Power Plant at the Salton Sea KGRA

Distribution:

T. R. Fick

J. W. Hankin

B. Holt

A. V. Sims

M. R. Scheve

K. F. Mirk

A. L. Austin

G. E. Tardiff

B. C. McCabe

J. L. Featherstone

T. C. Hinrichs

E. Zajac

W. O. Jacobson
Date of Conference: December 16, 1977

Location: The Ben Holt Co.

Pasadena

- Bechtel

- Ben Holt

- Ben Holt

- DOE

- LBL

- LLL

- LLL

- Magma

- Magma

- Magma

- Magma

- SDGEE

\section{At tendance:}

J. W. Hankin

A. Renton

- Bechte1

B. Holt

- Bechtel

A. J. L. Hutchinson - Ben Holt

A. V. Sims

- Ben Holt

B. C. McCabe

- Magma

J. L. Featherstone - Magma

E. Zajac

- Magma

W. O. Jacobson

- SDGEE

\section{Plant Interface Parameters}

Bechte1 presented a draft of the results of Task 2, Plant Interface Parameters. The values presented were based on agreements reached in previous meetings, review of available data and best estimates. The following major revisions were agreed to after discussion:

1. Production Wellbottom Temperature - Changed from $478^{\circ} \mathrm{F}$ to $500^{\circ} \mathrm{F}$, declining linearly by $18^{\circ} \mathrm{F}$ in 30 years. Plant design will be based on $482^{\circ} \mathrm{F}$ instead of $460^{\circ} \mathrm{F}$.

2. We11 Layout - Changed from that shown in Holt Co. Drawing 7506-D-3202 to one production island and one injection island. The revised layout is based on slant drilling with 600 to 700 -foot bottomhole spacing. A revised layout sketch will be supplied by Magma. 
3. Well Location - The production well island will be located near the center of the P-1 and P-2 area shown on Drawing 7506-D-3202. The injection well island will be located near the center of the eastern edge of the P-1 and P-2 area.

4. Well Depth - Production wells are to be slant drilled to depths from 2,000 feet to 4,000 feet. Injection wells will be drilled to depths between 1,500 to 1,800 feet.

5. Plant Location - The plant will be located near the production well island, at approximately the center of the P-1 and P-2 area.

6. Well Cost - Production well cost is $\$ 300,000$ per well and injection well cost is $\$ 200,000$ per well.

7. Effluent Brine Treatment - An effluent brine treatment system will be provided at the plant boundary. The treatment system will provide for removal of precipitated solids. In the case where the brine entering the plant has been acidified, the effluent brine will be neutralized.

8. Injection Lines - Injection lines will be insulated.

9. Water - Cooling water makeup, over that provided by condensate, will be available at industrial rates.

10. Environmental - Plant design is to be based on a standard of no more than $30 \mathrm{ppb}$ of hydrogen sulfide at the plant boundary. Surface condensers will be required in the steam flash design to meet this requirement.

11. Materials - The materials recommendations provided by LLL will be studied by the Bechtel materials group.

12. Design Without Acid Addition - A plant design based on no acid addition and a scaling rate of one mil per hour will be studied.

13. Injection at $300^{\circ} \mathrm{F}$ - The plant design for injection at $300^{\circ} \mathrm{F}$ will not require brine acidification or scaling allowance.

Settling Tank Tests

Magma reported that in preliminary tests a two-hour hold time in settling tanks reduces suspended solids to $40 \mathrm{ppm}$ and that the brine is at saturation with respect to silica.

\section{Schedule}

New schedules and cost estimates will be prepared that reflect the revisions made to the plant interface parameters.

AVS/jc

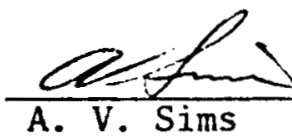


Feasibility Study of a Geothermal Power Plant at the Salton Sea KGRA

Distribution:

T. R. Fick - - Bechtel

J. W. Hankin - Bechte1

S. B. Hebbar - Bechtel

A. Renton - Bechte1

A. N. Rogers - Bechtel

T. E. Walsh - Bechtel

B. Holt - Ben Holt

A. Sims - Ben Holt

M. Scheve - DOE

K. F. Mirk - LBL

R. L. Fulton - LBL

A. L. Austin - LLL

G. E. Tardiff - LLL

J. Featherstone - Magma

T. C. Hinrichs - Magma

W. O. Jacobson - SDG\&E
Date of Conference: January 6, 1978

Location: $\quad$ San Diego Gas \& Electric

Subject: $\quad$ Status Review

Prepared by: J. W. Hankin

\section{Attendance:}
T. R. Fick
- Bechtel
W. O. Jacobson - SDG\&E
J. W. Hankin - Bechte1
B. Holt
- Ben Holt
J. Featherstone - Magma
A. Sims - Ben Holt
L. Brussfield - Magma
G. E. Tardiff - LLL
A. P. Kelley - DOE
R. L. Fulton - LBL

\section{Study Status}

Ben Holt stated that they are about a week behind on their Task 4, base case binary cycle, work compared to their schedule dated December 28 , 1977 .

Bechtel delivered their proposal and schedule for Phases I, II and III of the study. Bechtel also presented a preliminary site plot plan developed under Bechtel Task 3.2 as a generic plan for the study, and the draft report for Bechtel Task 2 of the study, plant interface parameters.

\section{Discussion and Conclusions}

1. Plot Plan: SDG\&E stated that the Bechtel preliminary plot plan is accepted for further development and Holt agreed to follow the general layout in preparing the binary plant design. The following additional comments were made: 
- Magma commented that the location of the production well islands might be changed. It was agreed to accept this as a "risk item" for further action and included as such in the Phase I report.

- It was agreed that injection lines would be routed above ground to avoid problems in burying them, since the site water table is at the two-foot level; and that the acceptability of having these pipes above ground will also be indicated as a risk item under Bechtel Task 4.

- Magma stated that the diked settling pond shown is acceptable. It was agreed that for the feasibility study, the pond will have plastic lining plus 4 inches of concrete.

2. Plant Parameters: The Bechtel Task 2 draft report on Interface Parameters was reviewed and the following items were agreed upon:

- The materials in the report will be used for the Phase I study and any potential changes will be considered part of the risks which will be included in the Phase I report.

- A brine filter system, prior to injection, will be designed with the following assumptions:

- Feed from pond has 40 ppm suspended solids with good filter cake. Brine into pond from plant contains 140 ppm suspended solids.

- $50,000 \mathrm{gpm}$ of sludge will be dewatered.

- Sludge has 16 percent by weight of solids.

- Sludge disposal is by hauling at $\$ 10$ per ton.

- Scaling rates and corrosion allowances presented in the writeup will be used for the Phase I conceptual designs.

- GLEF experience in scale cleaning will be used in developing $O \& M$ costs. The GLEF experience, for a 1 mil per hour scaling rate with a two week shutdown after 1000 hours of operation, indicates a cleaning cost of $\$ 15,000$. Approximately 50 percent of this cost is for chemicals and the remainder is outside labor. The operating crew (two individuals per shift, 3 shifts) also participates in the cleaning operation. For the Phase I study, it will be assumed that cleaning can be accomplished in two weeks, the outside labor will be $\$ 7,500$, and the chemical cost will be rationed from the GLEF to the conceptual plant designs on an exposed square foot basis. 
3. Alternative Approach to Solids Removal: George Tardiff urged that an alternative approach to solids removal prior to brine reinjection be considered and it was agreed that this suggestion should be included in the R\&D section of the Phase I report. The approach involves slowing down the solids precipitation. This can be accomplished by injecting the noncondensible gases, mainly carbon dioxide, which cause the $\mathrm{pH}$ to decrease to 4 and results in the precipitation of lead sulfide. This precipitate is easily filtered. The overall result is that silica precipitation is delayed approximately 10 hours which will allow the fluid to be injected far into the reservoir before precipitation occurs.

4. Equipment in Brine Service: Based on GLEF experience, it was agreed that pumps and valves in brine service are critical items for future $R \& D$ effort and should be included as risks in the Phase I report.

5. Materials Evaluation: Bill Jacobson indicated that the review of materials by the Bechtel Materials Group which was discussed in previous feasibility study meetings should not be part of the Phase I work, but should be an item for the R\&D section of the Phase I report. George Tardiff said that he would try to arrange a meeting of individuals with experience in evaluating materials for brine service. The meeting would include Tardiff, Tresitor who is retired from Shell Oil, Needham from the Bu Mines and a materials engineer from the Bechtel Materials Group. It would be conducted under the LLL contract.

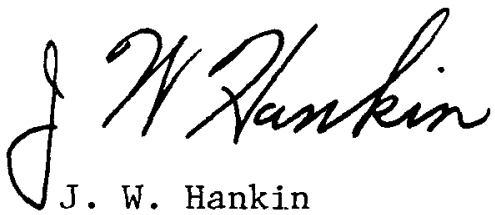


Feasibility Study of a Geothermal Power Plant at the Salton Sea KGRA

Distribution:

T. R. Fick

J. W. Hankin

S. B. Hebbar

A. Renton

A. N. Rogers

T. E. Walsh

B. Holt

A. Sims

M. Scheve

K. F. Mirk

R. L. Fulton

A. L. Austin

G. E. Tardiff

J. Featherstone

T. C. Hinrichs

W. O. Jacobson
Date of Conference: February 8, 1978

Location: Bechtel, San Francisco

Subject: $\quad$ Review of Preliminary Results

Prepared By: J. W. Hankin

\section{Attendance:}

T. R. Fick

J. W. Hankin

S. B. Hebbar

A. Renton

A. N. Rogers

A. Sims

R. L. Fulton
- Bechtel

- Bechtel

- Bechtel

- Bechte1

- Bechtel

- Bechtel

- Ben Holt

- Ben Holt

- DOE

- LBL

- LBL

- LLL

- LLL

- Magma

- Magma

- SDG\&E

\section{Status}

Bechtel had completed the conceptual designs and cost estimates for the flashed steam energy conversion processes and had transmitted all drawings and cost estimate tables to SDG\&E and Ben Holt last week. Ben Holt had completed the cost estimates for the binary energy conversion processes and had transmitted them to SDG\&E and Bechtel two days before this meeting. All drawings had not yet been completed and, therefore, the Bechtel review of the binary processes had not been completed.

\section{Discussion and Conclusions}

1. 300F minimum Injection Temperature: The cost estimates were reviewed and it was determined that for both the flashed steam and the binary processes the busbar energy production costs for the $300 \mathrm{~F}$ minimum injection temperature cases were higher than the no minimum temperature cases. It was agreed that the $300 \mathrm{~F}$ minimum injection temperature cases would be dropped from further consideration. 
2. Flashed Steam vs. Binary Process: The cost estimates were reviewed and the risks involved in the flashed steam and the binary processes were discussed. Based on generally lower busbar energy costs and lower overall risks, it was agreed that future GLEF activity should be directed primarily toward the flashed steam process.

3. Flashed Steam Process with Standby Equipment: Bechtel presented data which indicated that significant improvement in the busbar energy cost would result for the flashed steam process with unmodified brine if the design included three $50 \%$ trains of flash tanks. It was agreed that this should become the base case for the flashed steam processes.

4. Unmodified vs. Acidified Brine: The busbar energy cost for the flashed steam process using unmodified brine with standby flash tanks was shown to be slightly lower than that of the flashed steam process using acidified brine. It was agreed that the primary emphasis in future GLEF testing should be placed on the unmodified brine case, but that the acidified brine option should be kept open. Since high cost materials are required to operate with acifidied brine, rebuilding the GLEF to run these would be very expensive. It was agreed that the most cost effective approach would probably be to operate the GLEF with unmodified brine and construct a small-scale dual flash loop to operate with acidified brine. A possiblity would be for LLL to construct and operate the sma11-scale loop at their current site next to the GLEF.

5. Energy Cost Analyses: Due to possible differences in methodology used by Bechtel and Ben Holt in calculating busbar energy costs, Bechtel will run a check by calculating the energy cost for one binary case using the Ben Holt capital costs and other input data.

6. Mist Eliminators vs. Scrubbers: The current conceptual design for the flashed steam processes include mist eliminators. Bechtel indicated that the cost of mist eliminators is very similar to that of scrubbers and that this would be indicated in the Phase I report. It was agreed that no change should be made in the conceptual design for the purposes of the Phase I report. However, it was also agreed that performance of of these devices under transient conditions would be important and that Harry Biship should be contacted to obtain the latest information on scrubber performance at the GLEF. The risk analysis section of the Phase I report should indicate the imporatance of scrubbing and the Recommended GLEF Activities section should include tests of both mist eliminators and scrubbers.

7. Sand Traps: It was agreed that Bechtel will check with Magma on the need for sand traps in the brine production lines.

8. Production and Injection We1l Arrangement: LLL indicated some reservation regarding the arrangement of the injection wells in relation to the production wells. It was agreed that LLL will discuss this with Magma, but that the present layout will be used for the Phase I report.

9. Outline of Phase I Report: It was agreed that Bechtel will prepare an outline of the Phase I Interim Report and send copies to SDG\&E and Ben Holt. 
10. Risk Analysis and Recommended GLEF Activities: It was agreed that Ben Holt will take the lead in preparing the Risk Analysis for the Phase I report and that Bechtel will take the lead in preparing the Recommended GLEF Activities. Since Bechtel had alread begun to prepare a draft list of risks, it was also agreed that Bechtel would complete the list and transmit it to all study participants for review and comment.

11. Project Schedule: A target date for completing the draft of the Phase I Interim Report was set at March 1, 1978. However, it was recognized that this is a very tight schedule and that any significant problems would cause the target date to slip.

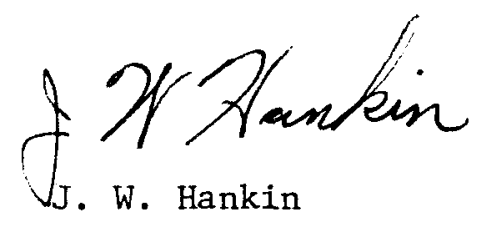




\section{CONFERENCE NOTES}

Feasibility Study of a Geothermal Power Plant at the Salton Sea KGRA

\section{Distribution:}
A. J. Bowles
T. R. Fick .
- Bechte1
- Bechtel
J. W. Hankin
- Bechtel
S. B. Hebbar
- Bechte1
A. Renton
A. N. Rogers
- Bechtel
T. E. Walsh
- Bechte1
Y. C. Wong
B. Ho1t
A. Sims
M. Scheve
K. F. Mirk
R. L. Fulton
A. L. Austin
G. E. Tardiff
- LLL
J. Featherstone - Magma
T. C. Hinrichs - Magma
W. O. Jacobson - SDG\&E
K. McKinnon - SDG\&E
J. M. Nugent - SDG\&E

Date of Conference: March 29, 1978

Location: SDG\&E, San Diego

Subject: Cost Estimates

Prepared by: J. W. Hankin

Attendance:

A. J. Bowles - Bechtel

J. W. Hankin - Bechtel

Y. C. Wong - Bechtel

A. Sims - Ben Holt

W. O. Jacobson - SDG\&E

K. McKinnon - SDG\&E

J. M. Nugent - SDG\&E

\section{Genera1}

It was agreed that Bechtel and Holt will prepare capital cost estimates in a format usable by SDG\&E as input to the SDG\&E computer program and that SDG\&E will then compute the bus bar energy production costs, including escalation. Assumptions and changes that were agreed upon in order to obtain the desired format and also to improve the cost estimates are detailed in the following paragraphs. Otherwise, the cost estimates will be prepared in accordance with Appendix A, "Cost Estimating Methodology" that is contained in the Draft Phase I Interim Report dated March 10, 1978. 
CONFERENCE NOTES

March 29, 1978

Page Two

\section{Capital Cost Estimates}

2.1 Equipment categories will be uniform in the capital cost estimate tables that are prepared by Bechtel and Holt.

2. 2 Construction costs, including subcontracts, will be broken down into labor and materials.

2.3 Commercial operation of the power plant will be assumed to begin in 1982 .

2.4 Escalation will be applied to the capital costs that are prepared in first-quarter 1978 dollars.

2.5 The escalation rate for materials or factory constructed equipment will be 6 percent through 1984 and $4-1 / 2$ percent thereafter.

2.6 The escalation rate for construction labor, including indirect costs, will be 8 percent through 1984 and $6-1 / 2$ percent thereafter.

2.7 Allowance for Funds During Construction (AFDC) will be assumed to be 8 percent per annum of the total construction plus owner's costs over a period of one-third of the construction schedule.

2.8 Escalation will be included in the capital cost tables.

3. Operation and Maintenance Costs

3.1 The escalation rate for operating labor and materials will be 6 percent through 1984 and $4-1 / 2$ percent thereafter. These will all be specified as fixed costs.

3.2 Well field operators', roustabouts', electrical and instrumentation technicians', mechanics', mechanical and well engineers' salaries and associated overhead plus operating chemicals and other materials for a base case field of 6 production wells and associated injection wells will be $\$ 150,000$ total per year.

3.3 The orfginal number of both production and injection wells, including spares, will be replaced once during the life of the plant. The replacement wells will be installed linearly over the plant lifetime. Additional wells to account for the projected decrease in flow per well with time will not be required since it is assumed that the production wells being replaced are those having the lowest flow rates. 
CONFERENCE NOTES

March 29, 1978

Page Three

3.4 Annual well field maintenance expense will include 0.5 percent of the capital cost of the surface facilities for both production and injection wells, plus $\$ 40,000$ per injection well for rework. No rework will be included for production wells; defective wells are assumed to be replaced.

3.5 Bechtel and Holt will review the operating crew requirements for the power plant.

4. Energy Costs

4.1 For State tax purposes, equipment lifetime will be assumed to be 28 years.

4.2 For Federal tax purposes, equipment lifetime will be assumed to be 23 years.

4.3 For book depreciation, equipment lifetime will be assumed to be 30 years.

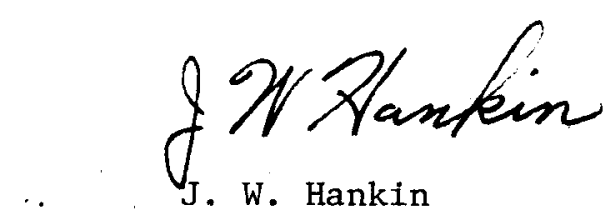

$\mathrm{JWH} / \mathrm{cm}$ 